Universidade de Brasília

Instituto de Relações Internacionais

ELISA DE ANANIAS FRAGA

A OMC E A TEORIA DAS NEGOCIAÇÕES ECONÔMICAS INTERNACIONAIS (JOHN ODELL): O COMPORTAMENTO DOS ATORES NAS CONFERÊNCIAS MINISTERIAIS DE CANCUN E DE HONG KONG

Brasília 


\section{A OMC E A TEORIA DAS NEGOCIAÇÕES ECONÔMICAS INTERNACIONAIS (JOHN ODELL): O COMPORTAMENTO DOS ATORES NAS CONFERÊNCIAS MINISTERIAIS DE CANCUN E DE HONG KONG}

Dissertação apresentada ao Instituto de Relações Internacionais da Universidade de Brasília para obtenção do título de Mestre em Relações Interacionais.

Área de concentração: Política Internacional e Comparada

Orientadora: Prof ${ }^{\mathrm{a}}$ Dr $^{\mathrm{a}}$ Maria Izabel Valladão de Carvalho

Brasília 
ELISA DE ANANIAS FRAGA

\title{
A OMC E A TEORIA DAS NEGOCIAÇÕES ECONÔMICAS INTERNACIONAIS (JOHN ODELL): O COMPORTAMENTO DOS ATORES NAS CONFERÊNCIAS MINISTERIAIS DE CANCUN E DE HONG KONG
}

Aprovada em:

Banca examinadora:

\begin{abstract}
Prof ${ }^{\mathrm{a}}$ Dr $^{\mathrm{a}}$ Maria Izabel Valladão de Carvalho Orientadora
\end{abstract}

\section{Prof $^{\mathrm{a}}$ Dr ${ }^{\mathrm{a}}$ Norma Breda dos Santos}

Prof. Dr. Ivan Tiago Machado de Oliveira

Prof. Dr. Alcides Costa Vaz (suplente) 
"The WTO was born out of negotiations; everything the WTO does is the result of negotiations"

(WTO, 2015) 


\section{RESUMO}

O objetivo deste trabalho é contribuir para a compreensão das causas do impasse na Rodada Doha da Organização Mundial do Comércio (OMC) mediante a aplicação da teoria de médio alcance sobre as negociações econômicas internacionais, concebida por John Odell (2000, 2006, 2009), à Quinta Conferência Ministerial da OMC, realizada em Cancun, em 2003, que terminou em impasse, e à Sexta Conferência Ministerial da OMC, realizada em Hong Kong, em 2005, que resultou na adoção de uma Declaração Ministerial. Investiga-se, especificamente, em que medida o processo de negociação dessas Conferências Ministeriais, incluindo os seus resultados, foi influenciado pelo comportamento dos negociadores e mediadores envolvidos. Parte-se da apresentação das abordagens tradicionais da Economia Política Internacional (EPI), que destacam variáveis relacionadas ao poder, às instituições, às ideias ou à dimensão doméstica, para, após, introduzir-se a teoria das negociações econômicas internacionais. Em seguida, os acontecimentos durante as duas Conferências e em seu processo de preparação são reconstruídos. Após, três hipóteses desenvolvidas por John Odell (2009) são "testadas" por meio da sua aplicação aos casos. Ao final, constata-se que, ao contrário das abordagens tradicionais da EPI, a teoria das negociações econômicas internacionais é capaz de explicar satisfatoriamente os diferentes resultados alcançados pelas Conferências Ministeriais de Cancun e de Hong Kong. Das três hipóteses "testadas", duas são confirmadas pela aplicação aos casos selecionados: a primeira hipótese, que associa alterações na melhor alternativa ao acordo (BATNA) a mudanças nas estratégias adotadas pelos negociadores, e a segunda hipótese, que relaciona as estratégias adotadas pelos negociadores à superação de impasses. A terceira hipótese, que vincula o comportamento dos mediadores à superação de impasses, gerou resultados inconclusivos.

Palavras-chaves:

Organização Mundial do Comércio (OMC). Conferências Ministeriais. Teoria das negociações econômicas internacionais. Processo de negociação. 


\begin{abstract}
This research aims to contribute to the understanding of the reasons for the stalemate at the Doha Round of the World Trade Organization (WTO) by applying the medium-range theory on international economic negotiations, designed by John Odell (2000, 2006, 2009), to the Fifth WTO Ministerial Conference, held in Cancun in 2003, which ended in deadlock, and the Sixth WTO Ministerial Conference, held in Hong Kong in 2005, which resulted in the adoption of a Ministerial Declaration. In particular, we investigate to what extent the negotiation process of these Ministerial Conferences, including their results, was influenced by the behavior of negotiators and mediators involved. The work starts with the presentation of the traditional approaches to International Political Economy (IPE), which highlight variablec related to power, institutions, ideas or the domestic dimension. Next, the theory of international economic negotiations is introduced. After a detailed description of the events that took place during the two Conferences and their preparatory processes, three hypotheses developed by John Odell (2009) are "tested" by its application to the cases. It was found that, unlike the traditional approaches to EPI, the theory of international economic negotiations has been able to satisfactorily explain the different results achieved by the Ministerial Conferences in Cancun and Hong Kong. Two of the three hypotheses were confirmed: the first hypothesis, which links changes in the best alternative to the negotiated agreement (BATNA) to changes in the strategies adopted by the negotiators, and the second hypothesis, which relates the strategies adopted by negotiators to the overcoming of deadlocks. The third hypothesis, which associates the behavior of mediators to the overcoming of deadlocks, generated inconclusive results.
\end{abstract}

Keywords:

World Trade Organization (WTO). Ministerial Conferences. Theory of international economic negotiations. Negotiation process. 


\section{LISTA DE QUADROS}

Quadro 1. Conferências Ministerias da OMC: 1995 - 2015 .......................................... 46

Quadro 2. Resultados da aplicação das hipóteses aos casos ...................................... 110 


\section{LISTA DE FIGURAS}

Figura 1. Desenho de pesquisa ................................................................... 16

Figura 2. Pontos de resistência, fronteira de possibilidades e resultados ............. 42 


\section{LISTA DE ABREVIATURAS E SIGLAS}

$\mathrm{ACP}$

$\mathrm{BM}$

BATNA

CARICOM

$\mathrm{CE}$

Cotton 4

DG

EPI

EUA

FIPs

FMI

FTA

G7

G10

G33

G20

G90

G110

GATS

GATT

GPA

GSP

ICTSD

ITA

NAMA

OMC

ONGs

ONU

OTAN
Grupo de países da África, Caribe e Pacífico

Banco Mundial

Melhor Alternativa ao Acordo

Comunidade do Caribe

Comissão Europeia

Grupo de países formado por Benin, Burkina Faso, Mali e Chade

Diretor-Geral da OMC

Economia Política Internacional

Estados Unidos da América

Cinco Partes Interessadas

Fundo Monetário Internacional

Acordo de Livre Comércio

Grupo dos Sete

Grupo dos Dez

Grupo dos Trinta e Três

Grupo dos Vinte

Grupo dos Noventa

Grupo dos Cento e Dez

Acordo Geral sobre o Comércio de Serviços

Acordo Geral sobre Tarifas e Comércio

Acordo sobre Compras Governamentais

Sistema Geral de Preferências

International Centre for Trade and Sustainable Development

Acordo sobre Tecnologia da Informação

Acesso a Mercados em Bens Industriais

Organização Mundial do Comércio

Organizações Não-Governamentais

Organização das Nações Unidas

Organização do Tratado do Atlântico Norte 
PD

PED

PMDR

PTAs

SPS

TBT

TPRM

TRIMs

TRIPS

TPP

TTIP

UE

UNCTAD
Países Desenvolvidos

Países em Desenvolvimento

Países de Menor Desenvolvimento Relativo

Acordos Comerciais Preferenciais

Acordo sobre Medidas Sanitárias e Fitossanitárias

Acordo sobre Barreiras Técnicas ao Comércio

Mecanismo de Revisão de Política Comercial

Acordo sobre Medidas de Investimentos Relacionadas ao Comércio

Acordo sobre Aspectos dos Direitos de Propriedade Intelectual

Relacionados ao Comércio

Parceria Transpacífico

Parceria Transatlântica para o Comércio e o Investimento

União Europeia

Conferência das Nações Unidas para o Comércio e o

Desenvolvimento 


\section{SUMÁRIO}

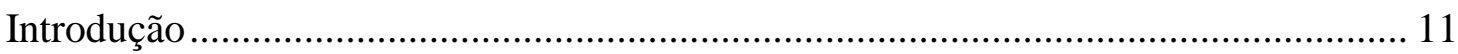

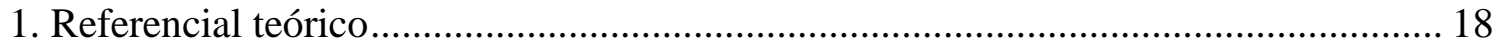

1.1 Revisão de literatura................................................................................18

1.1.1.Explicações baseadas no poder.......................................................... 18

1.1.2 Explicações baseadas na instituição ........................................................ 20

1.1.3 Explicações baseadas nas ideias ............................................................ 23

1.1.4 Explicações baseadas na dimensão doméstica ........................................... 25

1.2 Teoria das negociações econômicas internacionais (John Odell) ...................... 31

1.2.1 Primeira premissa: racionalidade circunscrita ............................................ 31

1.2.2 Segunda premissa: endogeneidade das instituições.................................... 37

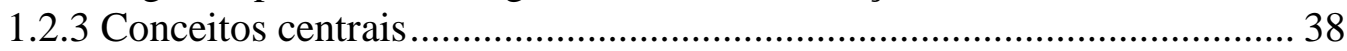

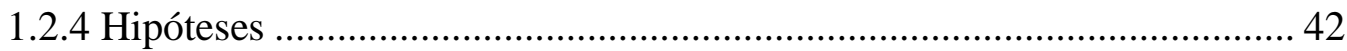

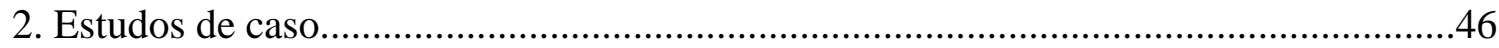

2.1. Antecedentes (de Marraqueche a Doha) ........................................................... 46

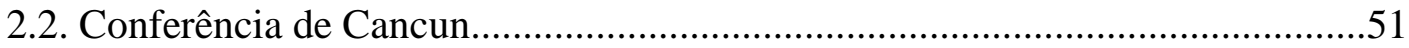

2.2.1 O dia-a-dia da Conferência de Cancun...................................................... 57

2.2.1.1 Primeiro dia - Quarta-feira, 10 de setembro de 2003 ........................ 57

2.2.1.2 Segundo dia - Quinta-feira, 11 de setembro de 2003 ........................ 61

2.2.1.3 Terceiro dia - Sexta-feira, 12 de setembro de 2003 ............................ 63

2.2.1.4 Quarto dia - Sábado, 13 de setembro de 2003 ..................................... 65

2.2.1.5 Quinto dia - Domingo, 14 de setembro de 2003 ............................... 67

2.3 Entre Cancún e Hong Kong: o Pacote de Julho de 2004 .................................... 71

2.4 Conferência de Hong Kong ............................................................................... 72

2.4.1 O dia-a-dia da Conferência de Hong Kong .............................................. 80

2.4.1.1 Primeiro dia - Terça-feira, 13 de dezembro de 2005 ......................... 80

2.4.1.2 Segundo dia - Quarta-feira, 14 de dezembro de 2005 ....................... 81

2.4.1.3 Terceiro dia - Quinta-feira, 15 de dezembro de 2005 ........................ 83

2.4.1.4 Quarto dia - Sexta-feira, 16 de dezembro de 2005 ............................. 84

2.4.1.5 Quinto dia - Sábado, 17 de dezembro de 2005 ................................ 86

2.4.1.6 Sexto dia - Domingo, 18 de dezembro de 2005 ................................ 89

2.5. Desdobramentos posteriores (do pós-Hong Kong a Nairobi) ........................... 90

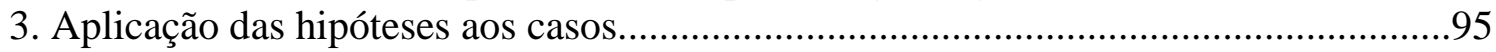

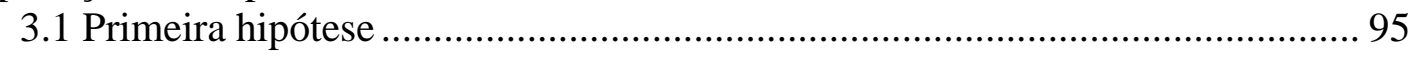

3.1.1 Conferência Ministerial de Cancun ....................................................... 95

3.1.2 Conferência Ministerial de Hong Kong …………………………....... 98

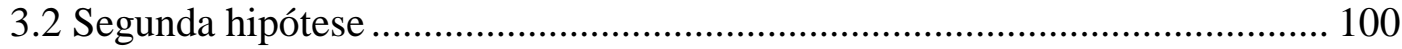

3.2.1 Conferência Ministerial de Cancun ...................................................... 100

3.2.2 Conferência Ministerial de Hong Kong …………….......................... 103

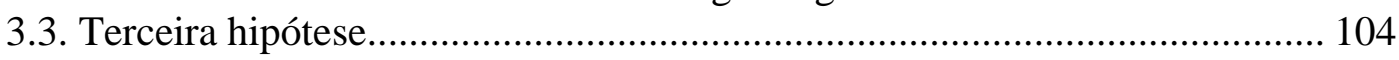

3.3.1 Conferência Ministerial de Cancun ..................................................... 105

3.3.2 Conferência Ministerial de Hong Kong …………................................ 108

3.4 Conclusão do Capítulo 3 ........................................................................... 109

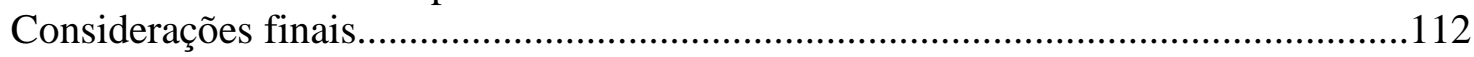

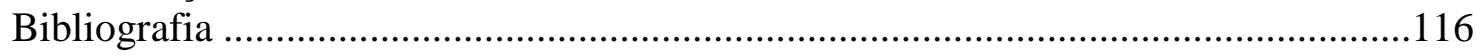




\section{Introdução}

A Organização Mundial do Comércio (OMC) foi criada com o propósito de suceder o Acordo Geral sobre Tarifas e Comércio (GATT) como framework institucional para a cooperação acordo transitório, destinado a operar apenas até a entrada em vigor da Organização Internacional do Comércio (ITO), que vinha sendo negociada desde 1944. Entretanto, o abandono do projeto da ITO, em 1950, levou a que, na prática, a atuação institucional do GATT se estendesse de 1947 até 1995 (NARLIKAR, 2005).

Nessas quase cinco décadas, foram realizadas no âmbito do GATT oito rodadas de negociações, que tornaram o sistema multilateral de comércio progressivamente mais liberal (OMC, 2015). A última e mais longa das rodadas de negociações do GATT foi a Rodada Uruguai, que se estendeu de 1986 a 1994, e resultou na criação da OMC. "Com isso - explica Oliveira (2012, p. 10) - o regime multilateral de comércio, criado após a Segunda Guerra Mundial, ganhou força enquanto instituição reguladora das trocas internacionais.”

A Rodada Uruguai resultou ainda na adoção obrigatória, por parte dos Membros da recém-criada Organização (antigas "Partes Contratantes" do GATT), de um conjunto de acordos sobre "novos temas", que expandiram substancialmente a regulamentação comercial multilateral. Diferentemente do GATT, centrado em barreiras tarifárias e outras medidas de fronteira, os novos acordos disciplinavam medidas de proteção e regulamentação doméstica, em matérias como investimentos, serviços e propriedade intelectual.

O Acordo Constitutivo da OMC, também conhecido como Acordo de Marraqueche, recebeu quatro anexos. O promeiro deles (Anexo 1) trazia os compromissos substantivos assumidos por todos os Membros da Organização, e se subdividia em três partes. O Anexo 1A incorporou o texto atualizado do antigo GATT (agora denominado GATT 1994), bem como os demais instrumentos acerca do comércio de bens - entre outros, o Acordo sobre Agricultura, o Acordo sobre Medidas Tarifárias e Fitossanitárias (SPS), o Acordo sobre Barreiras Técnicas ao Comércio (TBT), o Acordo Antidumping e o Acordo sobre Medidas de Investimentos Relacionadas ao Comércio (TRIMs). Já os Anexos 1B e 1C apresentavam, respectivamente, o Acordo Geral sobre o Comércio de Serviços (GATS) e o Acordo sobre Aspectos dos Direitos de Propriedade Intelectual Relacionados ao Comércio (TRIPS). 
Por sua vez, o Anexo 2 ao Acordo de Marraqueche instituiu um novo mecanismo de solução de controvérsias, mais robusto que o anteriormente adotado pelo GATT $^{1}$; o Anexo 3 criou um mecanismo para a revisão das políticas comerciais domésticas; e o Anexo 4 apresentou os chamados acordos plurilaterais, compromissos substantivos de adesão facultativa aos Membros da OMC.

As negociações da Rodada Uruguai foram orientadas pelo princípio do "compromisso único" (single undertaking), que dispõe que todos os temas sejam negociados e aprovados ao mesmo tempo - "nada está acordado até que tudo esteja acordado." Em tese, ao permitir o estabelecimento de trade offs, este princípio favoreceu a aceitação de compromissos que dificilmente seriam aprovados por todos os negociadores caso fossem tratados separadamente. Durante a Rodada Uruguai, acredita-se que ele foi diretamente responsável pelo sucesso na inserção dos "novos temas" no sistema multilateral de comércio.

Com efeito, Sylvia Ostry atribui os resultados da Rodada Uruguai a uma grande barganha (great bargain) entre as, então, Partes Contratantes do GATT: os países do Sul teriam aceito os compromissos nos "novos temas" e a criação da OMC, com seu sistema reforçado de resolução de controvérsias, em troca da perspectiva de abertura dos mercados dos países do Norte para as exportações agrícolas e de bens manufaturados intensivos em trabalho, particularmente têxteis. A percepção de que a barganha seria desequilibrada em desfavor dos países do Sul, embora tenha crescido nos anos subsequentes, não estava, segundo a autora, tão presente à época das negociações (OSTRY, 2000).

À OMC foram atribuídas as funções de 1) facilitar a implementação, a administração e a operação dos diversos acordos adotados pelos Membros no âmbito da Organização, tanto os multilaterais, de adesão obrigatória a todos os Membros, quanto os plurilaterais (função executiva); 2) servir como fórum de negociação entre os Membros da OMC nas matérias cobertas pelos acordos da Organização e em temas novos, desde que pertinentes às relações comerciais multilaterais (função legislativa); e 3) administrar o novo mecanismo de solução de controvérsias (função judicial) $^{2}$.

\footnotetext{
${ }^{1}$ Os textos legais dos acordos da OMC podem ser acessados na página da internet da OMC.

${ }^{2}$ Além das três funções citadas, é também atribuição da OMC administrar o Mecanismo de Revisão de Política Comercial (TPRM), que, por meio de revisões periódicas, busca dar transparência às políticas e práticas comerciais dos Membros da Organização, bem como examinar seu impacto sobre o sistema multilateral de comércio. A classificação das funções da OMC como executiva, judiciária e legislativa é encontrada, entre outros, em VanGrasstek (2013).
} 
Conquanto o fortalecimento do braço judicial do sistema multilateral de comércio após a criação da OMC seja amplamente reconhecido ${ }^{3}$, são indiscutíveis as dificuldades que a Organização vem enfrentando para avançar em sua função legislativa (VANGRASSTEK, 2013, p. xi-xii). Com efeito, a primeira rodada de negociações comerciais da OMC- a Rodada Doha foi lançada por ocasião da Quarta Conferência Ministerial da OMC, realizada em 2001, e ainda está em andamento, embora a sua conclusão tivesse sido originalmente prevista para 2005.

A esta altura, não é possível prever quando a Rodada Doha será concluída, nem quais serão seus resultados (VANGRASSTEK, 2013, p. xi). A incerteza elevou-se após a conclusão da Décima Conferência Ministerial da OMC, realizada em Nairóbi, em dezembro de 2015: nessa ocasião, pela primeira vez desde 2001, alguns Membros da Organização recusaram-se a reafirmar o seu comprimisso em relação à Rodada Doha.

Contudo, enquanto as discussões na OMC seguem em ritmo lento, os acordos de livre comércio (FTAs) e os acordos comerciais preferenciais (PTAs), incluindo aqueles celebrados entre países desenvolvidos e em desenvolvimento, crescem em número e relevância. Entre 1991 e 2011, a quantidade de acordos preferenciais multiplicou-se por quatro (OMC, 2011). Iniciativas recentes de grande magnitude, como a conclusão das negociações da Parceria Transpacífico (TPP), que envolve importantes traders da região Ásia-Pacífico, incluindo Estados Unidos (EUA), Japão, México e Canadá, e as discussões para o estabelecimento da Parceria Transatlântica para o Comércio e o Investimento (TTIP), entre EUA e União Europeia (UE), reforçam essa tendência.

A demanda por maior liberalização do comércio e do investimento parece, portanto, evidente, a despeito do pequeno avanço recente no plano multilateral. A esse respeito, Hoeckman e Mavroidis (2012, p.1) afirmam:

The many PTAs in force today indicate that the problems in the WTO are not a reflection of an unwillingness of governments to make binding trade policy-related commitments embedded in treaty instruments, but prima facie, an unwillingness to make similar commitments on a WTO-wide basis.

Diferentes abordagens da Economia Política Internacional (EPI) têm buscado explicar as razões das dificuldades enfrentadas pelo braço negociador da OMC. Via de regra, as análises enfatizam aspectos estruturais, como a distribuição do poder ou a dimensão institucional;

\footnotetext{
3 “The WTO's dispute settlement process is, by far, the most used and most effective international dispute settlement process. (...) The system uses high quality decision-makers, has the power to enforce a significant and specific body of international law and has control over a trade sanction that seems to be of just the right strength both to be politically acceptable and to generally induce compliance." (BARTON et al, 2006: p. 210)
} 
variáveis ideacionais e aquelas relacionadas à interação entre os planos doméstico e internacional também têm sido frequentemente exploradas. Na parte inicial do primeiro capítulo deste trabalho, essas abordagens serão apresentadas.

Em contraste, este trabalho buscará contribuir para a compreensão do impasse na Rodada Doha a partir da investigação do processo das negociações, tal como proposto pela teoria de médio alcance concebida por John Odell (2000, 2006, 2009) para explicar as negociações econômicas internacionais. Essa abordagem teórica será apresentada na parte final do primeiro capítulo, com destaque para as premissas (racionalidade circunscrita e endogeneidade das instituições), os conceitos centrais (negociação, resultados, estratégias, táticas, ponto de resistência, BATNA, zona de acordo) e as três hipóteses (ODELL, 2009) que relacionam o comportamento das delegações e dos mediadores ao processo de negociação, incluindo seus resultados.

O segundo capítulo apresentará os casos que serão estudados neste trabalho: a Quinta Conferência Ministerial da OMC, realizada em Cancun, em 2003, e a Sexta Conferência Ministerial da OMC, realizada em Hong Kong, em 2005. De forma a afastar o risco de enviesamento da pesquisa em razão da seleção de casos com variáveis dependentes semelhantes, buscou-se selecionar um par contrastante de Conferências Ministeriais ${ }^{4}$ : enquanto a reunião de Cancun foi concluída sem que houvesse acordo entre os negociadores, a reunião de Hong Kong resultou na adoção, por consenso, de uma Declaração Ministerial. Ao mesmo tempo, buscou-se selecionar um par de casos, tanto quanto possível, “comparáveis” (LIPJHART, 1971, p. 687): nesse sentido, a escolha de duas Conferências Ministeriais realizadas dentro do intervalo de apenas dois anos permitiu que diversas características que influenciam o processo negociador fossem tratadas como constantes, à luz do que preconiza o "método da diferença" descrito por John Stuart Mill ${ }^{5}$.

Como se verá, as abordagens tradicionais da EPI não explicam satisfatoriamente os diferentes resultados alcançados pelas Conferências Ministeriais de Cancun e de Hong Kong. A

\footnotetext{
${ }^{4}$ Desde a sua criação, em 1995, a OMC realizou dez Conferências Ministeriais. Desse total, cinco Conferências resultaram em Declarações Ministeriais aprovadas por unanimidade pelos Membros presentes: a Primeira (Cingapura, 1996), a Segunda (Genebra, 1998), a Quarta (Doha, 2001), a Sexta (Hong Kong, 2005), a Nona (Bali, 2013) e a Décima (Nairobi, 2015) Conferências Ministeriais. Em quatro Conferências não foram emitidas Declarações Ministeriais: na Terceira (Seattle, 1999), Quinta (Cancun, 2005), Sétima (Genebra, 2009) e Oitava (Genebra, 2011) Conferências Ministeriais.

${ }^{5}$ Embora Mill tenha sustentado que o método da diferença não seria aplicável às ciências sociais, dada a impossibilidade de selecionar dois casos suficientemente semelhantes, o próprio Lijphart defende que essa é uma visão baseada em padrões científicos excessivamente exigentes (Lijphart, 1971, p. 687).
} 
fim de avaliar o potencial explicativo da teoria das negociações econômicas internacionais proposta por John Odell $(2000,2006,2009)$ diante desses mesmos casos, no terceiro capítulo as três hipóteses desenvolvidas pelo autor (ODELL, 2009) ${ }^{6}$ serão “testadas", por meio da aplicação às Conferências Ministeriais selecionadas.

Assim, o objetivo geral deste trabalho é identificar em que medida os processos de negociação das Conferências Ministeriais da OMC, particularmente os seus resultados, são influenciados pelo comportamento dos negociadores e mediadores envolvidos. O primeiro objetivo específico do trabalho é reconstruir os acontecimentos e o comportamento das delegações e dos mediadores durante a Conferência Ministerial de Cancun, realizada em 2003, e a Conferência Ministerial de Hong Kong, realizada em 2005, bem como no processo de preparação para esses eventos. O segundo objetivo específico é "testar" as três hipóteses desenvolvidas por John Odell (2009), que associam o comportamento das delegações e dos mediadores ao processo de negociação, incluindo os seus resultados, por meio da sua aplicação a essas mesmas Conferências.

Neste trabalho, será adotado o método do estudo de caso comparado (ODELL, 2009, p. 13). A par de uma contextualização histórica com base nos eventos centrais das dez Conferências Ministeriais da OMC, enfatizando seus impactos para as negociações da Rodada Doha, cada um dos dois casos selecionados serão analisados em profundidade, utilizando-se o process tracing como ferramenta analítica. A partir daí, o trabalho servirá tanto ao propósito de controlar as hipóteses desenvolvidas por Odell (2009), que serão "testadas" nos dois casos sob análise, quanto ao de explicar (LIM, 2010, pp. 20-21), já que os resultados poderão contribuir para o desenvolvimento da teoria (indução analítica).

Como a seleção dos casos foi feita a partir da variável dependente, com base nos resultados das negociações, trata-se de um desenho de pesquisa retrospectivo, tal como definido por King, Keohane e Verba (1994, p. 141). As variáveis independentes, ou explicativas, são: 1) o comportamento dos negociadores: 1.1) percepção da melhor alternativa ao acordo - BATNA e 1.2) estratégia de negociação adotada; e 2) o comportamento dos mediadores: 2.1) adoção de

\footnotetext{
${ }^{6}$ As hipóteses foram desenvolvidas com base no estudo de outro par contrastante, mas comparável, de Conferências Ministeriais da OMC: a Terceira Conferência Ministerial, realizada em Seattle, em 1999, e a Quarta Conferência Ministerial, realizada em Doha, em 2001.

${ }^{7}$ Tratando de um número reduzido de casos, é importante destacar que eventual resultado negativo não deverá implicar na rejeição da teoria. Como ressaltado por Odell, "No pair of cases is sufficient to establish causality or eliminate all alternative interpretations with airtight certainty." (2009, p. 295)
} 
procedimentos inclusivos e 2.2) apresentação de texto negociador robusto. A variável dependente é o processo de negociação das Conferências, incluindo os seus resultados.

O desenho de pesquisa incorpora mais de uma unidade de análise e, assim, classifica-se como desenho de casos múltiplos (embutido) ("multiple-case (embedded)" - YIN, 2009, p. 46). A unidade de análise principal é o processo de negociação das Conferências Ministeriais da OMC. A unidade de análise embutida (“embedded”) é o comportamento, nessas negociações, das delegações e dos mediadores. O contexto é o ambiente institucional da OMC, incluindo as regras procedimentais que se aplicam às negociações multilaterais ${ }^{8}$. A figura abaixo representa este desenho de pesquisa:

Figura 1. Desenho de pesquisa

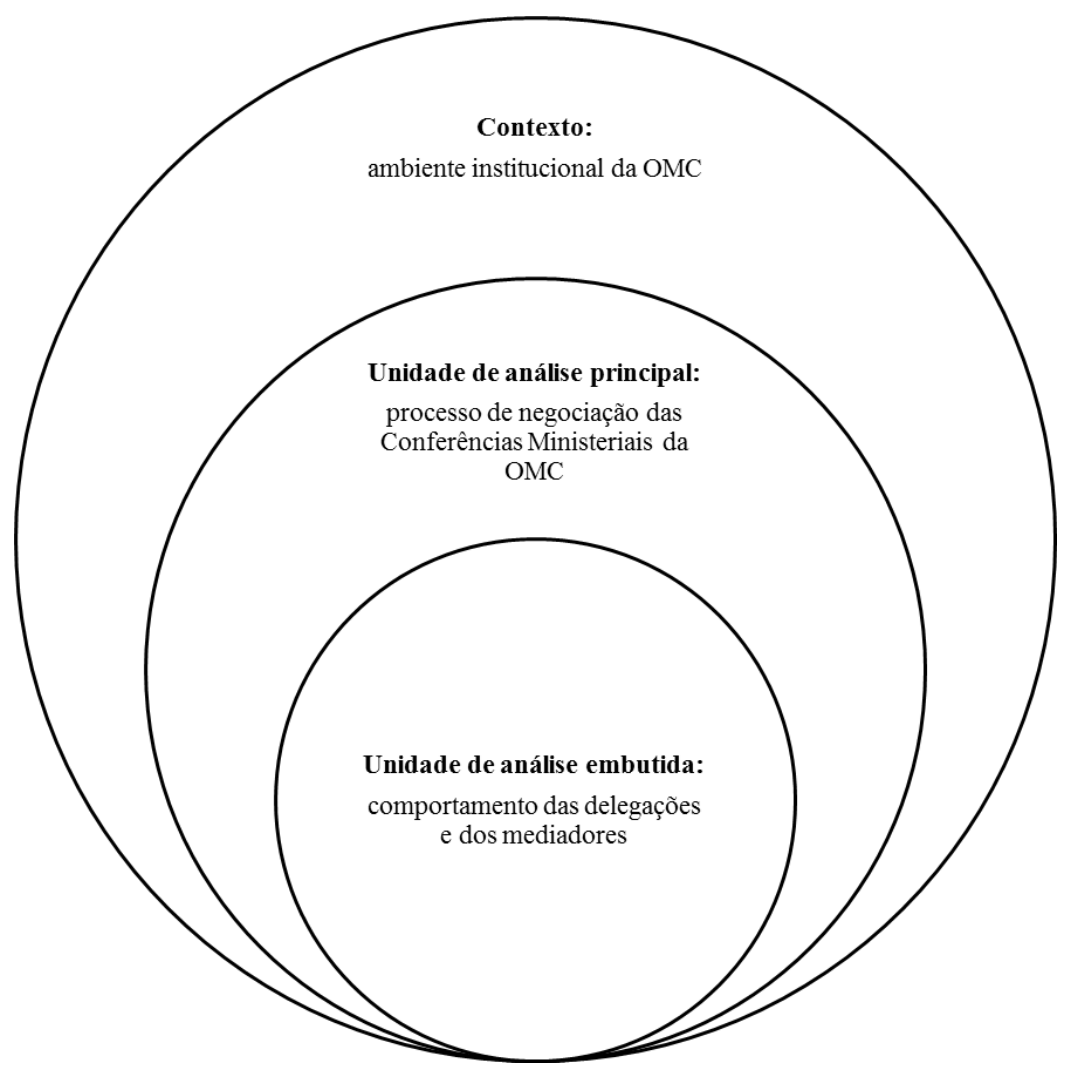

Fonte: Elaboração própria com base em Yin (2009)

Far-se-á uso tanto de fontes primárias e como de fontes secundárias. Entre as fontes primárias, destacam-se Declarações e Decisões Ministeriais, bem como os textos normativos da

\footnotetext{
${ }^{8}$ Neste trabalho, a atuação do Diretor-Geral, dos chairs e do Secretariado da OMC, quando não observar estritamente as regras da instituição (tanto escritas como costumeiras), será considerada como variável independente, inserida na unidade de análise embutida.
} 
OMC e declarações e discursos de negociadores e mediadores. Como fontes secundárias, recorrer-se-á, entre outros, a artigos acadêmicos e estudos descritivos ou analíticos que tenham por objeto os processos negociadores na OMC; à cobertura e divulgação das negociações nas páginas da OMC; a relatórios produzidos por observadores, como o International Centre for Trade and Sustainable Development (ICTSD, que produz o periódico Brigdes); e, por fim, a material jornalístico. 


\section{Referencial teórico}

Este capítulo divide-se em duas partes. Na primeira parte, como revisão da literatura, serão apresentadas as abordagens que tradicionalmente têm sido utilizadas para explicar as questões centrais da Economia Política Internacional (EPI), incluindo as negociações multilaterais de comércio. Trata-se de abordagens que privilegiam, como fatores explicativos, variáveis relacionadas ao poder, às instituições, às ideias ou à dimensão doméstica.

Na segunda parte deste capítulo, será introduzida a teoria de médio alcance sobre as negociações econômicas internacionais desenvolvida por John Odell (2000, 2006, 2009), cujas hipóteses relacionadas às negociações comerciais internacionais (ODELL, 2009) serão posteriormente "testadas" nas duas Conferências Ministeriais que constituem os casos estudados neste trabalho.

\subsection{Revisão da literatura}

De acordo com Helen Milner (1998), a EPI busca explicação para quatro questões centrais: 1) como superar os paradoxos da teoria econômica clássica (por exemplo, a existência do protecionismo) incorporando variáveis políticas; 2) como as escolhas de política externa econômica por parte dos Estados são afetadas pela inclusão de fatores domésticos e internacionais, tanto econômicos como políticos; 3) por que alguns Estados crescem rapidamente e se desenvolvem, enquanto outros não têm o mesmo sucesso; e 4) qual o impacto da economia internacional na política doméstica, ou seja, da globalização das economias nacionais.

Segundo a autora, ao buscar responder a essas questões os trabalhos da disciplina têm recorrido a quatro grupos de fatores: variáveis relacionadas ao poder; variáveis relacionadas às instituições; variáveis relacionadas às ideias; e variáveis relacionadas à dimensão doméstica (MILNER, 1998). A seguir, serão apresentadas as abordagens baseadas em cada um dos quatro grupos de fatores apontados por Milner (1998).

\subsubsection{Explicações baseadas no poder}


Milner (1998) aponta que autores associados à tradição realista, como Robert Gilpin e Stephen Krasner (1982), identificam a distribuição do poder entre os Estados como fator preponderante para responder às questões centrais da EPI. Assim, para Gilpin, a EPI consiste na "reciprocal and dynamics interaction in international relations of the pursuit of wealth and the pursuit of power" (GILPIN apud COHEN, 1990),

Considerando-se os trabalhos de orientação realista, a mais importante contribuição teórica para a economia política é a teoria da estabilidade hegemônica (JONES, 2001). Originalmente enunciada por Charles Kindelberger, e posteriormente sistematizada por Kenneth Waltz, ela destaca o papel de Estados líderes (ou hegemons) para a garantia da abertura e da estabilidade econômica internacional, e aponta como as mudanças na distribuição de capabilities (capacidades) afetam a economia mundial (MILNER, 1998).

Abordagens realistas têm orientado com sucesso trabalhos sobre o impasse nas negociações da Rodada Doha da OMC. Muitos autores, como o diplomata brasileiro Braz Baracuhy (2012), atribuem as dificuldades da Rodada a uma reconfiguração na distribuição do poder econômico global, antes concentrado nos EUA e na Europa e agora compartilhado também por China, Índia e Brasil.

Na mesma linha, Robert Baldwin (2007, p.265) ressalta mudanças na estrutura de poder econômico e político relativo dos Membros da OMC como "causa fundamental" das dificuldades encontradas na Rodada:

A fundamental reason for the disappointing results of the Doha Round (...) has been the significant increase in the economic and political power of developing countries such as India, Brazil, China and South Africa in recent years. The developing countries are now major players in multilateral WTO trade negotiations, and no negotiating round can be successfully concluded without their support. The emphasis that these countries have placed on shifting the distribution of the gains from trade much more in their own favor has proved difficult for developed countries to accept

Em sintonia com a teoria da estabilidade hegemônica, Baldwin (2007) complementa sua análise destacando que os problemas da Rodada devem-se também à queda relativa do poder político e econômico dos EUA. Tal fato teria reduzido a propensão desse país para aceitar os custos associados à abertura comercial e à promoção do objetivo comum de elevar as taxas de crescimento nos países em desenvolvimento.

Para Amrita Narlikar (2010), a importância crescente do Brasil, da Índia e da China na governança do comércio internacional é evidenciada por pelo menos três indicadores: a grande e crescente participação no comércio internacional, particularmente da China; o ativismo 
concertado, exercido por meio de coalisões de países em desenvolvimento, como o G2097; e a presença crescente em fóruns-chaves de tomada de decisão, tanto dentro da OMC (integrando os novos agrupamentos que substituíram o antigo Uuad $^{10}$ ) e quanto fora da Organização.

Ocorre que, conquanto certamente auxiliem na compreensão das causas dos impasses nas negociações da Rodada Doha, os fatores destacados pela tradição realista não são capazes de explicar as razões dos diferentes resultados nas Conferências Ministeriais de Cancun e de Hong Kong. Em primeiro lugar, em que pese o movimento ascendente de China, Índia e Brasil, não se pode afirmar que entre 2003 e 2005 a distribuição de capabilities entre os Estados foi substantivamente alterada ${ }^{11}$.

Além disso, uma explicação baseada na teoria da estabilidade hegemônica assumiria como variável explicativa um hipotético fortalecimento do poder hegemônico durante o período (já que a conferência de Hong Kong, ao contrário da de Cancun, resultou em consenso), quando na verdade observava-se exatamente à tendência contrária, como ressaltado, entre outros, por Baracuhy (2012), Baldwin (2007) e Narlikar (2010).

\subsubsection{Explicações baseadas na instituição}

Ainda conforme Milner (1998), um segundo grupo de autores destaca a atuação de instituições internacionais como a Organização das Nações Unidas (ONU), o Banco Mundial (BM), o Fundo Monetário Internacional (FMI) e a OMC como fator determinante para a definição do funcionamento da economia internacional. Robert Keohane (1984), por exemplo, sustenta que enquanto o hegemon pode ser necessário para o estabelecimento das instituições

\footnotetext{
${ }^{9}$ Como se verá de forma mais detalhada mais à frente, o chamado Grupo dos Vinte (G20) comercial surgiu no dia 20 de agosto de 2003, durante as preparações para a Conferência Ministerial de Cancun da OMC, quando seus membros produziram um documento com proposta de como deveria ser abordado o tema da Agricultura durante a Conferência. Ele foi orginalmente composto por África do Sul, Argentina, Bolívia, Brasil, Chile, China, Colômbia, Costa Rica, Cuba, El Salvador, Equador, Filipinas, Guatemala, Índia, México, Paquistão, Paraguai, Peru, Tailândia e Venezuela (DELGADO; SOARES, 2005).

${ }^{10} \mathrm{O}$ termo Quad é usado para se referir ao grupo de quatro países membros da OMC, todos eles desenvolvidos Canadá, União Europeia (UE), EUA e Japão - que, desde os tempos do Acordo Geral sobre Tarifas e Comércio (General Agreement on Tariffs and Trade - GATT), frequentemente adotava posições similares, funcionando como uma coalisão informal (NARLIKAR, 2004) e exercendo grande influência nas decisões do sistema multilateral de comércio.

${ }^{11}$ Nesse curto intervalo de tempo não irromperam grandes crises ou guerras: após a pequena recessão dos anos 20002001, entre 2003 e 2005 a economia mundial vivia anos de prosperidade e crescimento, ao passo que, na seara militar, seguia a Guerra ao Terror, lançada pelos EUA após os ataques de 11 de setembro de 2001.
} 
internacionais, uma vez criadas, elas tendem a ser preservadas pelos Estados (já que o esforço para mantê-las é menor que o esforço para construir novas instituições), e passam a ser fundamentais para a estabilidade e a abertura, não apenas da economia, mas também da política internacional $^{12}$. Para Keohane (1984), a principal função das instituições internacionais é reduzir os custos de transação e a incerteza e, assim, facilitar negociações que levem a acordos mutuamente satisfatórios entre governos.

Parcela representativa dos estudos que tratam da OMC e buscam explicar os problemas enfrentados durante a Rodada Doha tem enfatizado a influência dos aspectos institucionais sobre o processo negociador na OMC.

Um aspecto frequentemente ressaltado é a exigência de que novos direitos e obrigações sejam aprovados por consenso entre os Membros - embora o Acordo de Marraqueche (Acordo Constitutivo da OMC) preveja que algumas decisões possam ser tomadas pela maioria dos Membros, na prática todas as decisões da OMC, desde a sua criação, foram consensuadas (SUTHERLAND et al., 2004), excetuadas apenas as deliberações sobre novas acessões e waivers (BARTON et al, 2008) ${ }^{13}$. Tem sido dito que a regra do consenso torna ineficiente o "braço legislativo" da OMC, já que a resistência de uma minoria pode impedir o avanço das negociações, em prejuízo da totalidade dos Membros da Organização (SUBRAMANIAN, $2013)^{14}$.

Tem-se alegado também que o impasse atual pode ser atribuído à adoção do princípio do single undertaking (compromisso único), que exige que todos os temas inseridos em uma única Rodada sejam negociados e aprovados ao mesmo tempo - "nada está acordado até que tudo esteja acordado" ${ }^{\prime \prime}$. Argumenta-se que a rigidez dessa regra procedimental estaria impedindo a

\footnotetext{
${ }^{12}$ Por identificar os regimes internacionais como bens públicos para cuja criação o hegemon costuma desempenhar papel fundamental, a abordagem de Keohane também pode ser entendida como uma das versões da teoria da estabilidade hegemônica. Essa classificação, entretanto, foi rejeitada pelo próprio autor (GUZZINI, 2002)

${ }^{13}$ Enquanto para as negociações prevalece a regra do consenso, no braço judiciário da OMC é adotado o consenso reverso: com o novo mecanismo de solução de controvérsias, um painel será iniciado sempre que solicitado, a não ser que haja consenso no Órgão de Solução de Controvérsias em sentido contrário. O mesmo vale para a adoção dos relatórios dos painéis e do Órgão de Apelação.

${ }^{14}$ Contrapõe-se a esta visão, favorecendo a manutenção da regra do consenso, Joost Pauwelyn (2004), entre outros.

${ }^{15} \mathrm{Em}$ tese, ao permitir o estabelecimento de trade offs, este princípio favorece a aceitação de compromissos que dificilmente seriam aprovados por todos os negociadores caso fossem tratados separadamente. Durante a Rodada Uruguai (1986-1994), quando foi adotado pela primeira vez, o single undertaking foi apontado como responsável pelo sucesso na inserção de novos temas, como serviços e propriedade intelectual, no sistema multilateral de comércio. A esse respeito, Sonia Rolland afirma: "While there is still some debate as to the timing of introductionof the single undertaking, all agree that by 1991,when the delineation of the scope of the negotiations was fairly crystalized, the single undertaking was seen as key to closing the Round with a series of independentagreements.
} 
conclusão de acordos pontuais em temas menos controversos (HUFBAUER; SCHOTT, 2012; ROLLAND, 2010).

Vários autores têm sugerido que as negociações de Doha poderiam ser destravadas pela flexibilização dessas regras procedimentais (HOEKMAN; MAVROIDIS, 2012; HUFBAUER; SCHOTT, 2012; ROLLAND, 2009). Entre outras possibilidades, a mudança poderia ampliar a existência dos chamados acordos plurilaterais, que seriam adotados apenas pelos Membros interessados, sem o risco de veto por um grupo pouco representativo de países, e sem a exigência de acordo simultâneo para o conjunto de temas cobertos pela Rodada ${ }^{16}$.

A OMC caminharia, assim, para um modelo de geometria variável (VANGRASSTEK; SAUVÉ, 2006), afastando-se do padrão adotado desde a Rodada Uruguai, em que se busca, como regra, compromissos vinculantes para a totalidade dos Membros, e aproximando-se da abordagem de "clube dos clubes" (LAWRENCE, 2006) que orientou as negociações do GATT até a Rodada Tóquio (1973-1979) ${ }^{17}$.

Além da regra do consenso e do single undertaking, outro aspecto institucional que tem sido apontado como responsável pelo lento avanço da Rodada Doha é o caráter de memberdriven organization (organização dirigida pelos Membros): embora haja na OMC um Secretariado que responde por questões administrativas e executa algum trabalho técnico (como a elaboração dos Trade Policy Reviews), sua autoridade e tamanho são muito limitados em comparação com outras organizações econômicas internacionais, como o FMI e o Banco

Ultimately, the once-separate negotiations on services (Punta del Este Declaration Part II) and the negotiations on intellectual property all became part of the single undertaking during the Uruguay Round.” (2012, p.225).

${ }^{16}$ Entre as matérias que poderiam ser tratadas pelos novos acordos plurilaterais, têm sido mencionadas a liberalização de serviços; a desvalorização cambial (em coordenação com o FMI); medidas relacionadas à emissão gases de efeitos estufa e energia; redução tarifária em setores industriais específicos; e regras para empresas estatais (HUFBAUER; SCHOTT, 2012). Os novos acordos plurilaterais se somariam aos dois acordos plurilaterais atualmente administrados pela OMC: o Acordo sobre Tecnologia da Informação (International Technology Agreement - ITA) e o Acordo sobre Compras Governamentais (Government Procurement Agreement - GPA), ambos de adesão facultativa aos Membros da Organização.

${ }^{17} \mathrm{Em}$ 2004, a possibilidade de flexibilização das regras da OMC foi analisada pelo Corpo Consultivo que, a pedido do então Diretor-Geral da Organização, Supachai Panitchpakdi, elaborou o texto que se tornou conhecido como Relatório Sutherland (SUTHERLAND et al., 2004). Neste caso, as recomendações foram cautelosas. Quanto ao consenso, foi sugerido apenas que os Membros reavaliassem a regra quando se tratasse de decisões meramente procedimentais. Além disso, recomendou-se que sempre que um Membro bloqueasse uma medida com amplo consenso, essa decisão fosse justificada por escrito, e o Membro declarasse tratar-se de "interesse nacional vital". O Relatório sugeriu ainda que a abordagem plurilateral fosse reavaliada e considerada como alternativa, embora tenha excluído expressamente que eventual flexibilização se aplicasse já à Rodada Doha. Destacando que essa abordagem traria de volta ao sistema multilateral de comércio uma estrutura de filiação multiclasse (que, como visto, vigorou até a Rodada Tóquio), o Relatório alerta que ao invés de levar a OMC adiante, a negociação de acordos plurilaterais poderia representar um retrocesso. 
Mundial $^{18}$ (NARLIKAR, 2005; ODELL, 2009). Outra diferença da OMC em relação a essas instituições, e que contribuiria para os problemas da Rodada, é a inexistência formal de um órgão representativo pequeno, que possa servir de locus para tentativas de superação de impasses (ODELL, 2009).

É certo que as abordagens que privilegiam fatores institucionais jogam luz sobre aspectos importantes relacionados ao insucesso das negociações da Rodada Doha. No entanto, da mesma forma que as explicações baseadas no poder, elas não parecem apropriadas para explicar os diferentes resultados em Cancun e Hong Kong, já que as mesmas limitações institucionais que constrangiam as negociações da Terceira Conferência Ministerial, em 2003, estavam também presentes na Quarta Conferência Ministerial, em 2005.

\subsubsection{Explicações baseadas nas ideias}

A terceira abordagem apresentada por Milner (1998) privilegia as explicações nãomaterialistas para as questões centrais da EPI. Dentro desse grupo, a "abordagem das ideias", adotada por Keohane e Judith Goldstein (1993), propõe que as ideias são fatores importantes para explicar as escolhas de políticas; ideias dominantes, que capturam amplos segmentos da comunidade de policymakers, definem as ações dos Estados. Um segundo subgrupo de explicações não-materialistas, conforme Milner, consiste na abordagem construtivista, representada por Peter Katzenstein, Ronald Jepperson e Alexander Wendt, para quem a construção social das identidades dos Estados constrange as suas escolhas, induzindo-os a certos comportamentos.

O trabalho de John Ruggie (1982) sobre o surgimento e a manutenção da ordem econômica internacional do pós-Segunda Guerra talvez seja a principal referência de interpretação do sistema multilateral de comércio por meio das ideias. Segundo Andrew Lang, um número grande e crescente de estudiosos do comércio internacional tem cedido ao apelo do conceito de embedded liberalism ("liberalismo embutido") cunhado por Ruggie, de forma que "it now occupies a significant place on our conceptual horizon" (Lang, 2006, p. 81).

\footnotetext{
${ }^{18}$ Essa característica, como recorda Amrita Narlikar (2005), é uma herança dos tempos do GATT: "This memberdriven character of the WTO derives directly from the GATT, whose lack of organizational status placed all responsibilities for conducting any treaty-related business on the signatories themselves" (p. 35).
} 
Segundo Ruggie (1982), a estrutura da economia internacional que emergiu com a reconstrução institucional ao final da Segunda Guerra Mundial conciliou atributos defendidos tanto pela ortodoxia liberal internacionalista quanto pelos críticos do liberalismo:

This was the essence of the embedded liberalism compromise: unlike the economic nationalism of the thirties, it would be multilateral in character; unlike the liberalism of the gold standard and free trade, its multilateralism would be predicted upon domestic interventionism (RUGGIE, 1982, p. 393).

Assim, o compromisso do embedded liberalism, ao mesmo tempo em que se baseou nos princípios do multilateralismo e livre comércio, incorporou mecanismos intervencionistas destinados a minimizar os custos dos ajustes domésticos à abertura, como salvaguardas e outras exceções, isenções e restrições (RUGGIE, 1982).

Ao se referir ao acordo que deu origem à estrutura econômica do Pós-Segunda Guerra, Dani Rodrik (2000) também ressalta o fato de que ele sacrificou o objetivo de completa integração econômica internacional. O "compromisso de Bretton Woods", na denoninação de Rodrik, compartilha as características atribuídas por Ruggie ao embedded liberalism:

The essence of the Bretton Woods-GATT regime was that countries were free to dance to their own tune as long as they removed a number of border restrictions on trade and generally did not discriminate among their trade partners (RODRIK, 2000, p. 183).

Para Rodrik, esse compromisso foi abandonado nos anos 1980, entre outras razões porque os acordos comerciais começaram a tratar de temas que antes eram reservados às esferas nacionais, como defesa da concorrência ou segurança e saúde (2000). Andrew Lang (2006) também afirma que, para muitos estudiosos, o embedded liberalism, entendido como uma visão política compartilhada, foi ao menos parcialmente desintegrado.

Segundo Ruggie (1982), o compromisso de embedded liberalism foi possível apenas a partir da construção e do compartilhamento de um conjunto específico de objetivos sociais por parte dos países desenvolvidos, particularmente EUA e Reino Unido. Nesse sentido, chama a atenção de Lang (2006, p. 100) o silêncio da narrativa construída a partir do conceito de embedded liberalism quanto aos aspectos ligados ao desenvolvimento: "development does not figure in the self-understanding of the trade regime and facilitating development does not count high among its purposes."

Em uma análise construtivista dos conflitos que caracterizam a política comercial contemporânea, Valbona Muzaka e Matthew Louis Bishop (2014) manifestam preocupação, justamente, com a ausência de propósitos sociais compartilhados entre os países desenvolvidos e 
os países emergentes mais poderosos. Para os autores, sem essa base não será possível construir, para o comércio multilateral, um conjunto de regras que sejam estáveis, equitativas e legítimas.

Nesse mesmo espírito, Erik Andersson ( ) ressalta como o interesse dos diversos participantes da Rodada Doha divergem. Enquanto em alguns casos, como para o Brasil e países de menor desenvolvimento relativo ${ }^{19}$ que buscam ampliar seu acesso a mercados, o foco é econômico, para outros Membros (como EUA e UE, e também Índia e China) o interesse na Rodada é eminentemente político ${ }^{20}$. Para superar o impasse em Doha, Andersson sugere que essas questões normativas sejam discutidas abertamente na OMC.

Assim como as abordagens que privilegiam o poder ou as instituições, as abordagens baseadas nas ideias por certo contribuem para a compreensão de aspectos fundamentais do sistema multilateral do comércio e, em particular, da Rodada Doha. A ausência de um conjunto de propósitos sociais compartilhados pela totalidade dos Membros da OMC, por exemplo, de fato parece explicar, ao menos em parte, as dificuldades enfrentadas nas negociações da Rodada.

As abordagens das ideias, entretanto, não parecem capazes de esclarecer as razões por que as Conferencias de Cancun e de Hong Kong chegaram a resultados fundamentalmente distintos: não há razões para supor que no curto intervalo entre 2003 e 2005 processos sociais tenham levado a uma mudança ideacional que justifique os diferentes resultados nas duas Conferências Ministeriais.

\subsubsection{Explicações baseadas na dimensão doméstica}

Por fim, Milner (1998) apresenta um quarto grupo de autores, que destaca a influência dos fatores domésticos na Economia Política Internacional: enfatizando os processos políticos, esses autores examinam como a disputa entre atores domésticos define os interesses nacionais. $\mathrm{O}$ foco

\footnotetext{
${ }^{19}$ Neste trabalho, segue-se a classificação da ONU utilizada pela OMC para países desenvolvidos (PD) (Developed Countries), países em desenvolvimento (PED) (Developing Countries) e países de menor desenvolvimento relativo (PMDR) (Least Developed Countries). O World Economic Situation and Prospects ([WESP], 2014) oferece a classificação complete com todos os países membros da ONU.

${ }^{20}$ Segundo o autor, a Índia defende um acordo que seja considerado justo pelo eleitorado indiano; a China acredita haver cedido o suficiente no processo de adesão à OMC e está satisfeita em manter seu status de país em desenvolvimento durante a Rodada; os EUA mantém seu papel de liderança enquanto perpetuarem as negociações; e a EU segue apoiando as negociações multilaterais para assegurar a sua credibilidade diante das ex-colônias e demais Membros da OMC, enquanto os ganhos econômicos são assegurados em negociações de Economic Partnerships Agreements com países em desenvolvimento (ANDERSSON, 2012).
} 
ora repousa nos grupos sociais como detentores de preferências identificáveis no campo da EPI (como nos estudos de Jeffrey Frieden sobre o papel dos bancos e das firmas para a união monetária europeia), ora recai sobre o papel do Estado e dos policymakers para a definição e a execução da política econômica internacional (como nos trabalhos de Chalmers Johnson sobre o desenvolvimentismo asiático), ora ressalta, a um só tempo, tanto os atores societais quantos as instituições estatais (como nos trabalhos de Helen Milner, Judith Goldstein e Beth Simmons).

Conforme Milner, também pertencem a este quarto grupo autores como Robert Putnam, que, por meio de jogos de dois níveis, vinculam os ambientes nacionais e internacionais, e atores societais e estatais, com vistas a uma melhor compreensão das interações dos fatores complexos que constituem a Economia Política Internacional (MILNER, 1998).

Com efeito, Putnam (1988) sustenta que interpretações baseadas unicamente em causas domésticas e efeitos internacionais (à luz da "Segunda Imagem", de Waltz) ou causas internacionais e efeitos domésticos (à luz da "Segunda Imagem Invertida", de Gourevitch) representam análises de "equilíbrio parcial" que deixariam de lado a forma com que as políticas domésticas de diversos países se entrelaçam durante uma negociação internacional. Segundo Putnam, "we must aim (...) for 'general equilibrium' theories that account simultaneously for the interaction of domestic and international factors" (PUTNAM, 1988, p. 430).

Tendo isso em vista, Putnam (1988) sustenta que as negociações internacionais podem ser concebidas como “jogos de dois níveis”. O nível internacional (ou Nível I) é aquele em que efetivamente ocorre a negociação, e que culmina em um acordo provisório. Neste nível governos nacionais buscam maximizar a sua própria habilidade em atender às pressões domésticas, ao mesmo tempo em que tentam minimizar as consequências adversas da negociação.

O nível nacional (ou Nível II) é aquele em que os diversos grupos de eleitores discutem entre si a ratificação ${ }^{21}$ do acordo concluído no Nível I. Aqui, os grupos domésticos buscam seus interesses pressionando o governo a adotar políticas que lhes sejam favoráveis, ao passo que políticos buscam poder construindo alianças com esses grupos domésticos (PUTNAM, 1988).

Putnam denomina "win-set" o conjunto de acordos que recebem o apoio necessário para a sua aprovação no nível nacional. Para que haja acordo no nível internacional, é necessário haver alguma sobreposição entre os "win-sets" de todas as partes envolvidas na negociação. Portanto,

\footnotetext{
${ }^{21}$ A respeito da ratificação, Putnam esclarece: "it is sometimes convenient to think of ratification as a parliamentary function, but that is not essential. The actors at Level II may represent bureaucratic agencies, interest groups, social classes, or even 'public opinion'.” (1988, p. 436).
} 
quanto maior o "win-set", maiores as chances, ceteris paribus, de acordo - e vice-versa. Por outro lado, "win-sets" menores podem conferir, ceteris paribus, maior poder de barganha ao negociador (PUTNAM, 1988).

O tamanho dos "win-sets", por sua vez, é influenciado pelo custo de não-acordo ${ }^{22}$ : quanto mais baixo for esse custo, menor será o win-set, e vice-versa. Putnam ressalta, ainda, que pressões internacionais podem reverberar no nível doméstico, tanto expandindo quanto restringindo o tamanho do "win-set" (PUTNAM, 1988).

Outro aspecto importante ressaltado por Putnam é a vinculação entre temas em negociação no nível internacional, que pode alterar os resultados aceitáveis no nível nacional: é o que Putnam denomina "synergistic linkage" (articulação sinérgica). Segundo o autor, esse aspecto tende a se acentuar com o aprofundamento da interdependência econômica (PUTNAM, 1988).

Finalmente, Putnam chama atenção para o papel do negociador-chefe, que conecta o Nível I ao Nível II e, frequentemente, tem informações limitadas quanto ao "win-set" da contraparte negociadora - e, por vezes, quanto ao seu próprio "win-set". Como regra geral, o negociador é incentivado a minimizar o seu "win-set” diante da outra parte. É sua função convencê-la de que os acordos incluídos naquele "win-set" limitado serão, de fato, ratificados, ao passo que acordos ligeiramente mais favoráveis à contraparte provavelmente seriam rejeitados (PUTNAM, 1988).

Por outro lado, quando se buscam resultados que aumentem os ganhos compartilhados pelas partes, pode ser positivo o intercâmbio de informação precisa sobre os respectivos "winsets": "when the negotiators are seeking novel packages that might improve both sides" positions, misrepresentation of one's win-set can be conterproductive” (PUTNAM, 1988, pp. 452-453).

Diversos estudos das Relações Internacionais e da EPI recorrem ao arcabouço conceitual proposto por Putnam (1988). Peter Rosendorf e Helen Milner (2001), por exemplo, relacionam o desenho das instituições internacionais ao cálculo racional e às interações estratégicas dos países que as criam. Nesse sentido, a inserção de cláusulas de escape ("escape clauses",23) nos regimes cooperativos relaciona-se à instabilidade política doméstica: quanto maior a incerteza quanto ao

\footnotetext{
${ }^{22}$ O custo de não-acordo corresponde ao BATNA, na teoria de John Odell (2000, 2006, 2009). Normalmente, ele corresponde ao status quo.

23 "An escape clause is any provision of an international agreement that allows a country to suspend the concessions it previously negotiated without violating or abrogating the terms of the agreement" (ROSENDORF; MILNER, 2001, p. 830)
} 
cumprimento dos acordos internacionais no nível doméstico, maior a probabilidade de os líderes políticos negociarem acordos que contenham cláusulas de escape. As cláusulas de escape, assim, facilitam a compatibilização da cooperação internacional com a política doméstica, apresentandose como uma solução para o jogo de dois níveis enfrentado pelos líderes políticos (ROSENDORF; MILNER, 2001).

Os mesmos autores, agora tratando especificamente das negociações comerciais internacionais, apontam como as eleições legislativas influenciam tanto a ratificação quanto o teor dos acordos: "domestic politics in its simplest form shapes international negotiaton" (MILNER; ROSENDORF, 1997, p. 117). Os autores concluem que a probabilidade de rejeição de um acordo aumenta quando as divisões no governo aumentam; que mais divisão no governo tende a levar a resultados mais protecionistas; que a influência do Executivo junto ao país estrangeiro declina com a introdução de incerteza eleitoral; e que a habilidade do Executivo de extrair concessões no plano internacional declina com a incerteza ${ }^{24}$ (MILNER; ROSENDORF, 1997).

Já Christina Davis (2010) recorre aos jogos de dois níveis, incluindo a relação entre as eleições domésticas e as negociações internacionais, para interpretar os acontecimentos da Rodada Doha da OMC. Para esta autora, o timing das eleições em países como EUA e Índia atrasou o avanço nas negociações da Rodada:

Leaders, fearful that concessions in the trade negotiation could alienate powerful constituencies important for electoral victory, take inflexible positions while trade partners also hold back concessions to wait for the electoral outcome. (DAVIS, 2010, p. 57).

Por outro lado, Davis sustenta que o regime internacional de comércio auxilia a construção de apoio doméstico em favor do livre comércio e contra o protecionismo. A vinculação entre os diversos temas incentiva os exportadores a se mobilizarem, tendo em vista tanto o aprofundamento das concessões recíprocas, por meio das negociações, quanto eventual questionamento no Órgão de Solução de Controvérsias da OMC.

Além disso, para Davis, a crise por que passa a Rodada Doha tem a vantagem de mobilizar a mídia e os exportadores, evidenciando os trade-offs necessários para assegurar, no longo prazo, a abertura e a estabilidade no comércio internacional: "When the trade system

\footnotetext{
${ }^{24}$ Nesse sentido, os resultados encontrados por Milner e Rosendorf desafiam parcialmente a conjectura de Schelling (1960), que propõe que um negociador internacional pode apontar para uma legislatura agressiva ("a hawkish legislature", aquela que privilegia o uso da força em detrimento da discussão ou outras soluções mais pacíficas) para extrair mais concessões do país estrangeiro (MILNER; ROSENDORF, 1997, p. 120).
} 
appears on the brink, then opinion editorials and exporter associations will demand concessions for the sake of the trade system." (DAVIS, 2010, p. 58). A autora complementa: "While there are risks to moving forward by means of crisis, fading into obscurity in the realm of technocrats presents an even greater danger" (DAVIS, 2010, p. 58).

Ainda no contexto da Rodada Doha da OMC, Maria Izabel Valladão de Carvalho (2010) utiliza os jogos de dois níveis para avaliar a performance brasileira durante as negociações, particularmente em temas agrícolas. Considerando, entre outros fatores, as implicações do apoio doméstico às posições negociadoras brasileiras, a autora explora a hipótese de que o aumento do poder de barganha do Brasil nas negociações da Rodada decorreu da criação e participação do país em coalizões internacionais, especialmente o G20.

Na mesma linha, Haroldo Ramanzini e Marcelo Mariano (2014) examinam o processo decisório doméstico que resultou nas posições adotadas pelo Brasil no âmbito na coalizão do G20. Em particular, os autores buscam compreender em que medida a política externa brasileira, particularmente o posicionamento do país no âmbito do G20, sofre a influência de pressões domésticas; e, em termos mais específicos, avaliar a influência exercida por setores privados e pela burocracia estatal sobre a formulação e a implementação da estratégia de negociação brasileira na coalizão do G20.

Certamente as explicações baseadas nos fatores domésticos contribuem para a compreensão da conduta dos diversos países que participam da Rodada Doha da OMC. Tudo indica que a complexidade inerente às negociações comerciais multilaterais pode ser mais bem compreendida, como proposto por Putnam (1988), a partir dos jogos de dois níveis e, em particular, pelo recurso a conceitos como "win-sets”, articulação sinérgica e reverberação.

A relação proposta por Davis (2010) entre a crise por que passam as negociações na OMC e a mobilização da mídia e de setores exportadores, pode, da mesma forma, auxiliar na compreensão da dinâmica da Rodada, já que parece exemplificar adequadamente a influência recíproca e permanente entre a esfera doméstica e internacional.

No entanto, considerando-se o curto intervalo entre a Conferência Ministerial de Cancun e a Conferencia Ministerial de Hong Kong, não parece ser possível explicar as diferenças entre as duas reuniões apenas, ou mesmo principalmente, a partir dos fatores domésticos. Com efeito, considerando-se os principais atores nas negociações da $\mathrm{OMC}$, embora em muitos casos tenha havido eleições para o Poder Executivo ou para o Poder Legislativo entre 2003 e 2005, foi 
frequente a confirmação dos líderes anteriores; e, de todo modo, o que se percebeu foi uma continuidade nas políticas comerciais levadas a cabo por EUA, UE, Japão e Canadá (membros do Quad), bem como por Brasil, Índia e $\mathrm{China}^{25}$, principais players nas negociações comerciais multilaterais no período.

Da mesma forma, as cláusulas de escape presentes na normativa da OMC (por exemplo, a previsão de medidas de defesa comercial) eram as mesmas em 2003 e 2005. Finalmente, trabalhos como o de Carvalho (2010) e Ramanzini e Mariano (2014), que ressaltam o processo decisório que dá origem a posições negociadoras de países específicos, em determinados temas, durante a Rodada, conquanto apresentem elementos importantes para a compreensão das duas Conferências, não revelam descontinuidades capazes de explicar as diferenças encontradas entre 2003 e 2005.

Percebe-se, assim, que as abordagens que buscam explicar as questões centrais da Economia Política Internacional, e mais especificamente as negociações comerciais, a partir de variáveis relacionadas ao poder, às instituições, às ideias ou à dimensão doméstica não são capazes de revelar as razões dos diferentes resultados alcançados na Quarta Conferência Ministerial da OMC, realizada em Cancun, em 2003, e na Quinta Conferência Ministerial da OMC, realizada em Hong Kong, em 2005.

\footnotetext{
${ }^{25}$ Nos EUA, em novembro de 2004 George W. Bush foi reeleito para seu segundo mandato de quatro anos. Em março de 2005 o Representante para o Comércio norte-americano Robert Zoellick foi substituído por Rob Portman, que permaneceu no cargo até junho de 2006. A Trade Promotion Authority, no entanto, foi renovada em 2002 e vigorou até 2007. Nas mesmas eleições gerais de 2004 que reelegeram Bush, a maioria republicana no Senado e na Câmara de Representantes foi mantida e ampliada.

Na UE, em novembro de 2004 José Manuel Barroso sucedeu Romano Prodi na Presidência da Comissão Europeia (CE). No mesmo mês Peter Mandelson sucedeu Pascal Lamy como Comissário Europeu para o Comércio; Lamy deixou o cargo para assumir a função de Diretor Geral da OMC, que exerceu entre setembro de 2005 a setembro de 2013. Entretanto, apenas em outubro de 2006 a CE apresentou uma nova estratégia comercial, que incluiu o abandono da moratória para o início de novas negociações de acordos de livre comércio (Free Trade Agreements FTAs) (EVENETT, 2006).

No Japão, as eleições gerais de setembro de 2005 resultaram em vitória do Partido Liberal Democrático e na confirmação no cargo do Primeiro Ministro Junichiro Koizumi, no poder desde 2003. Koizumi permaneceu como Primeiro Ministro até setembro de 2006.

No Canadá, houve eleições parlamentares em junho de 2004. O Primeiro Ministro Paul Martin (no cargo desde novembro de 2003) e seu Partido Liberal venceram. Martin manteve-se no cargo até março de 2006, embora tenha governado sob minoria.

No Brasil, o Luís Inácio Lula da Silva ganhou a reeleição em 2006. Nos oito anos em que exerceu a Presidência (de 2003 a 2010), Lula manteve Celso Amorim como Chanceler.

Na Índia, em maio de 2004 houve eleições para a câmara baixa, que resultaram na indicação de Manmohan Singh (maio de 2004 a maio de 2014) como Primeiro Ministro. Singh havia atuado como líder da oposição na câmara alta do parlamento indiano durante o governo anterior.
} 
$\mathrm{Na}$ segunda parte desse capítulo, será introduzida a teoria de médio alcance sobre as negociações economicas internacionais desenvolvida por John Odell (2000, 2006, 2009), partindo de suas duas premissas (racionalidade circunscrita e endogeneidade das instituições) e passando por seus conceitos centrais para, ao final, apresentar três hipóteses relacionadas às negociações comerciais internacionais. Mais adiante, essas hipóteses serão "testadas" nas duas Conferências Ministeriais objeto deste trabalho.

\subsection{Teoria das negociações econômicas internacionais (John Odell)}

Enquanto a maior parte do conhecimento produzido na área da Economia Política enfatiza as estruturas, John Odell busca um conhecimento mais aprofundado do processo de negociação (ODELL, 2000). Assim, a teoria de médio alcance proposta por Odell não toma como elemento central o poder, as instituições, as ideias ou os fatores domésticos, mas o comportamento das delegações durante as negociações econômicas internacionais (ODELL, 2009, p. 2$)^{26}$.

Nesse sentido, para Dupont, Odell apresenta uma contribuição relevante:

Where there is a large literature on most issues and problems associated with this transformation [da economia mundial], there has been surprisingly little systematic attention to how states came up with the particular bargains that have gradually lowered barriers to economic exchange (DUPONT, 2002, p. 115).

A premissa de que os atores das negociações internacionais utilizam uma racionalidade circunscrita - tal como proposto, há seis décadas, pelo economista Herbert Simon (1955) - é um dos pilares da abordagem teórica proposta por John Odell (2000, 2006, 2009). A seguir, essa premissa será abordada em maior detalhe, desde suas origens, associadas à teoria da escolha racional clássica, até a sua aplicação na Economia Política Internacional.

Posteriormente, será apresentada a segunda premissa da teoria desenvolvida por Odell, os conceitos centrais da abordagem e, ao final, as hipóteses que serão testadas nos casos selecionados para este trabalho.

\subsubsection{Primeira premissa: racionalidade circunscrita}

\footnotetext{
${ }^{26}$ Aqui, esses aspectos são relevantes apenas na medida em que influenciam o comportamento dos negociadores.
} 
As teorias da escolha racional baseiam-se na definição de homo economicus, cujas características são apresentadas por Herbert Simon em seu artigo seminal "A behavioral model of rational choice":

Traditional economic theory postulates an 'economic man', who, in the course of being 'economic' is also 'rational'. This man is assumed to have knowledge of the relevant aspects of his environment which, if not absolutely complete, is at least impressively clear and voluminous. He is assumed also to have a well organized and stable system of preferences, and a skill in computation that enables him to calculate, for the alternative courses of action that are available to him, which of these will permit him to reach the highest attainable point on his preference scale (SIMON, 1955, p. 99).

Para John Elster, para uma ação ser considerada racional ela deve resultar de três decisões ótimas $^{27}$. Primeiro, é preciso ser a melhor forma de realizar os desejos de um indivíduo, dadas as suas crenças. Além disso, essas crenças devem, elas mesmas, serem ótimas, dada a informação disponível a ele. Finalmente, o indivíduo deve obter uma quantidade ótima de evidências, nem demais, nem de menos (ELSTER, 1989 apud KEOHANE, 2002).

Esse mesmo autor aponta três elementos que condicionam o comportamento racional dos indivíduos que se encontram diante de situações de escolha. O primeiro deles é o conjunto viável (feasible set), ou seja, o conjunto dos cursos de ação que satisfazem uma série de constrangimentos lógicos, físicos e econômicos. O segundo elemento é um conjunto de crenças racionais sobre a estrutura causal que determina, em uma situação específica, a quais resultados cada curso de ação levará. A terceira é uma classificação subjetiva das alternativas viáveis, que geralmente resulta da classificação dos resultados esperados de cada uma delas. Agir racionalmente portanto, significa, tão-somente, escolher o curso de ação mais bem classificado dentro do conjunto viável (ELSTER, apud KAHLER, 1998).

No campo das relações internacionais e da política externa, a capacidade dos tomadores de decisão de exercer uma "racionalidade pura" é associada a duas suposições adicionais. Primeiro, que os processos de tomada de decisão podem ser equiparados a indivíduos, que representam o papel, entre outros, de lideranças civis ou militares, de grupos políticos ou de grupos de interesse. Segundo, que a escolha pode ser analisada considerando-se apenas o comportamento de quem escolhe, ou seja, do Estado em análise, e não o produto da interação entre Estados (BRECHER, 1999).

A teóricos de inclinação realista, a escolha racional permite gerar previsões sobre o comportamento dos Estados a partir de informações relativamente esparsas sobre o ambiente. Em

\footnotetext{
${ }^{27}$ Isto é, que sejam as melhores possíveis.
} 
outras palavras, conhecer a estrutura da situação enfrentada pelo tomador de decisões permite ao realista ter "pistas" da ação estatal, já que os líderes, sendo egoístas racionais, respondem aos incentivos e constrangimentos do ambiente de forma calculada, buscando sempre elevar a sua riqueza, a sua segurança e o seu poder (KEOHANE, 1984). Assim, por essa perspectiva - que é criticada por Keohane - , "instead of having to do research on what leaders are actually thinking, we can obtain the necessary information merely by conducting thought experiments in our own offices" (KEOHANE, 1984, p. 66).

Entretanto, as suposições que sustentam a escolha racional vêm sendo alvo de questionamentos sistemáticos, tanto no campo da Economia quanto nas demais Ciências Sociais. O acúmulo de evidências empíricas do comportamento humano que divergem da teoria fez reduzir substancialmente o fascínio com a maximização da utilidade esperada, considerada o núcleo da racionalidade econômica (SIMON, 2000).

Em especial, os críticos ressaltam o papel que os constrangimentos não-materiais exercem sobre as escolhas. Keohane (1984), por exemplo, afirma que a racionalidade clássica é uma idealização, já que na prática os tomadores de decisão sujeitam-se não apenas a incertezas inerentes ao seu ambiente, mas também a limitações de suas próprias habilidades cognitivas (KEOHANE, 1984). Na mesma linha, Brecher (1999) sustenta que o conceito de racionalidade pura é um tipo ideal que não encontra correspondência na realidade.

Para Bendor (2010), ao ignorar constrangimentos cognitivos que afetam intensamente o julgamento e a escolha dos indivíduos, os modelos da racionalidade clássica (ou unbounded) deixam de considerar variáveis causais importantes, cujo impacto será tanto maior quanto mais difícil for o desafio enfrentado pelo tomador de decisões.

A vertente teórica que se tornou mais conhecida na Ciência Política ao questionar a teoria da utilidade esperada e propor a incorporação dos vieses cognitivos nos processos decisórios é a "Teoria dos Prospectos". Essa abordagem, desenvolvida por Kahneman ${ }^{28}$ e Tversky no final dos anos 1970, apontou diversos desvios em relação ao modo convencional de se explicar a escolha em condições de risco. De acordo com a "Teoria dos Prospectos", os indivíduos avaliam os resultados, sistemática e frequentemente, relacionando-os a um ponto de referência, e não calculando ganhos ou perdas líquidos; considerando o ponto de referência, os indivíduos têm

\footnotetext{
${ }^{28}$ Em reconhecimento pelo desenvolvimento da Teoria dos Prospectos, em 2002 Kahnemann dividiu o Prêmio de Ciências Econômicas em Memória de Alfred Nobel (Prêmio Nobel de Economia) com Vernon L. Smith.
} 
aversão ao risco em relação aos ganhos, e aceitação dos riscos em relação às perdas; e a ordem das preferências varia de acordo com o enquadramento ("framing") dos prospectos, em clara violação ao critério da invariância na escolha racional (KAHLER, 1998).

Ao tratar da "Teoria dos Prospectos", Deborah Elms (2008) ressalta as consequências profundas desses desvios para o comportamento dos indivíduos. O enquadramento de um tema como "ganho" ou "perda", por exemplo, a partir de um determinado ponto de referência (normalmente, o status quo), pode levar o indivíduo a tomar decisões opostas. A autora aponta, ainda, que a evidência experimental sugere que os indivíduos valorizam as perdas duas vezes mais do que valorizam os ganhos (ELMS, 2008).

Assim como a "Teoria dos Prospectos", o conceito de racionalidade circunscrita também resultou de questionamentos à teoria da escolha racional diante das evidências empíricas dos constrangimentos cognitivos.

Cunhado pelo economista Herbert Simon em meados do século passado, a racionalidade circunscrita corresponde à ideia de que os tomadores de decisão não são guiados apenas pela busca consistente de objetivos, considerando-se as propriedades do mundo externo; as escolhas são determinadas também pelo conhecimento que os indivíduos têm, ou não, do mundo. Além disso, ensina Simon, as escolhas derivam da habilidade (ou falta de habilidade) dos tomadores de decisão para utilizar esse conhecimento quando ele se torna relevante; para lidar com as consequências das suas ações; para conceber possíveis cursos de ação; para lidar com a incerteza, incluindo sobre as respostas dos demais atores às suas ações; e para se orientar entre os seus próprios e diversos desejos (SIMON, 2000).

No mundo real, ressalta Simon, a racionalidade é circunscrita porque essas habilidades são seriamente limitadas. Em outras palavras, "rational behaviour in the real world is as much determined by the 'inner environment' of people's minds, both their memory contents and their processes, as by the 'outer environment' of the world on which they act, and which acts on them" (SIMON, 2000, p. 25).

A racionalidade circunscrita, portanto, preocupa-se tanto com a racionalidade substantiva (ou seja, a qualidade do resultado) quanto com a racionalidade procedimental (ou seja, a qualidade do processo de decisão). Nesse sentido, ela pode ser entendida como uma 
representação, isto é, "a suitable framework for economic theories, where the product of decision cannot be predicted without knowledge of the process" (SIMON, 2000, p. 25) ${ }^{29}$.

É importante ressaltar que a racionalidade circunscrita não necessariamente leva à expectativa de resultados sub-ótimos. Ao contrário, como ressaltado por Sylvia Ostrom (1998), sob certas circunstâncias é possível prever, partindo dessa premissa, que os indivíduos alcancem resultados melhores do que aqueles previstos pela racionalidade clássica ("better than rational") (COSMIDES; TOOBY, 1994 apud Ostrom, 1998, p. 3). Segundo a autora, evidências empíricas indicam que a construção de condições tais como a reciprocidade, a reputação e a confiança podem tornar possível aos indivíduos resistir às tentações do auto interesse de curto prazo, permitindo, assim, a superação dos dilemas sociais ${ }^{30}$ - situações em que, prevê a teoria clássica da ação coletiva, o comportamento racional dos atores e a tentativa de maximização dos lucros individuais levariam a resultados sub-ótimos do ponto de vista coletivo (Ostrom, 1998).

A racionalidade circunscrita ocupa, assim, um lugar intermediário entre a tradição que sustenta a maximização ilimitada da utilidade (ou seja, a escolha racional clássica) e as abordagens que defendem a antirracionalidade ${ }^{31}$. Simon considera a racionalidade circunscrita uma variante da teoria da escolha racional, que se diferencia da orientação clássica, justamente, por considerar as limitações cognitivas do tomador de decisões. Conforme esclarecido pelo autor, o seu objetivo é aproximar a racionalidade clássica da realidade:

the task is to replace the global rationality of economic man with a kind of rational behavior that is compatible with the access to information and the computational capacities that are actually possessed by organisms, including man, in the kinds of environments in which such organisms exist (SIMON, 1955, p. 99).

Cabe destacar que no framework da racionalidade circunscrita os indivíduos fazem escolhas com o fim de alcançar os seus objetivos. Dessa forma, apesar de não atuarem de forma ótima, mas apenas "as effectively as they are able" (ODELL, 2006, p. 9), eles não deixam de agir racionalmente.

A primeira limitação enfrentada pelos tomadores de decisão é o fato de que, no mundo real, eles não têm à sua disposição toda a informação de que necessitam para otimizar a sua decisão. Em negociações comerciais internacionais, por exemplo, os negociadores geralmente são

\footnotetext{
${ }^{29}$ Para Simon (2000), a racionalidade circunscrita pode ser entendida como uma teoria, mas é difícil apontar exatamente quais previsões empíricas resultam da sua aplicação.

${ }^{30}$ Os dilemas sociais podem ser ilustrados pela Tragédia dos Comuns (HARDIN, 1969) e pelo Dilema do Prisioneiro (POUNDSTONE, 1992).

${ }^{31}$ A antirracionalidade, aqui, corresponde a abordagens que enfatizam as ideias e outros fatores não-materiais (como, por exemplo, as teorias construtivistas).
} 
incentivados a ocultar das contrapartes os seus pontos de resistência e a sua ordem de prioridades real (o que é mais importante e o que é secundário) dentre os diversos temas negociados (ODELL, 2006).

Além de comumente não estarem disponíveis aos demais, as posições negociadoras são eventualmente definidas $^{32}$, e frequentemente alteradas, no decorrer da negociação. Isso pode ocorrer tanto como resposta às estratégias adotadas pelos demais negociadores e pelo mediador ${ }^{33}$, quanto em reação ao comportamento do mercado ${ }^{34}$ (ODELL, 2006, p. 10).

A esse respeito, Ikle (apud LAX; SEBENIUS, 1991, p.476) destaca:

Normally, the parties have only a vague anticipation of the terms that they may expect to consider sufficiently desirable for preferring agreement to no-agreement. Fequently this anticipation is very faint... All the more reason to reject the popular notion of fixed mínima, which stand imovable from the begining to the end of a conference like goal posts in a ball game.

$\mathrm{Na}$ prática, portanto, ainda que tivesse acesso a todas as informações existentes, e pudesse antever todos os cursos de ação disponíveis ao início da negociação, não seria possível ao negociador com racionalidade limitada deduzir uma única estratégia ótima apenas e diretamente a partir dos interesses materiais envolvidos na negociação (ODELL, 2006).

Além do acesso à informação, outra limitação à escolha racional clássica é a capacidade computacional, limitada, dos indivíduos. Ao invés de processar toda a informação necessária para a maximização dos seus objetivos, os indivíduos, na prática, escolhem alternativas "suficientemente boas", que alcançam ou excedem determinados critérios, mas que, considerando-se o conjunto de alternativas disponíveis, não são necessariamente as melhores. Em outras palavras,

Faced with a choice situation where it is impossible to optimize, or where the computational cost of doing so seems burdensome, the decision maker may look for a satisfactory, rather than an optimal, alternative. (SIMON, 1997, p. 295)

Na prática, portanto, o negociador, ao decidir, é levado a tomar "atalhos mentais" (“mental short cuts"): considerar apenas algumas dentre as estratégias disponíveis; negligenciar

\footnotetext{
${ }^{32}$ Em sintonia com o visto anteriormente sobre os win-sets de Putnam, Odell ressalta que há situações em que os negociadores desconhecem os seus próprios valores de reserva: "Most delegations don't know their own bottom lines", afirma um negociador veterano citado pelo autor (ODELL, 2009, p. 11)

${ }^{33} \mathrm{Na}$ OMC, o papel de mediador é, via de regra, representado pelo Diretor-Geral (DG) e seu staff, mas também pode ser representado pelos Chairs dos diversos grupos negociadores, ou outros atores a que se atribua a função de facilitar a aproximação de posições e a superação de divergências, com vistas a se alcançar o consenso entre os Membros.

${ }^{34} \mathrm{O}$ negociador pode ser levado a reavaliar suas posições diante de alterações relevantes de indicadores de expectativa de mercado, como taxas de câmbio e índices de bolsas de valores, por exemplo. Ilustram essa situação as estratégias adotadas pelo México em resposta às alterações nas condições de mercado no decorrer das negociações de energia no âmbito do NAFTA, exploradas por Antonio Ortiz Mena L. N. (2006, p. 205-206).
} 
complexidades; e fazer julgamentos aproximados a respeito de riscos, pontos de resistência dos demais envolvidos na negociação e chances de sucesso. Por serem necessariamente subjetivos, esses julgamentos e essas escolhas estratégicas sujeitam-se a enviesamentos e a táticas de enquadramento ("framing tactics") ${ }^{35}$ e persuasão; em outras palavras, sujeitam-se ao processo negociador (ODELL, 2006, pp. 10-11).

Para John Odell (2000, 2002, 2006, 2009), a economia política é movida pela racionalidade circunscrita; por essa razão ele acolhe o framework proposto por Simon (1955). A utilização da racionalidade circunscrita na pesquisa sobre a economia política, para Odell, permite aperfeiçoar o conhecimento na área em termos empíricos, teóricos e práticos. Em termos empíricos, ela dedica mais atenção à maneira em que, de fato, as decisões são tomadas; em termos teóricos, um novo olhar para a escolha racional clássica e para o construtivismo pode auxiliar na transcendência de mais um debate das teorias de Relações Internacionais, desta vez entre essas duas orientações; finalmente, em termos práticos, conhecimento mais robusto sobre os processos de tomada de decisões pode tornar os estudos na área mais úteis (ODELL, 2002).

No caso específico das negociações da Rodada Doha da OMC, e em particular das duas Conferências Ministeriais da OMC que são objeto deste trabalho, o framework da racionalidade circunscrita permite identificar variáveis dependentes às quais é possível atribuir as diferenças encontradas nos dois processos negociadores, incluindo os resultados alcançados.

\subsubsection{Segunda premissa: endogeneidade das instituições}

Além da racionalidade circunscrita, outra premissa da teoria de médio alcance proposta por Odell (2000, 2006, 2009) é que as instituições são endógenas aos processos de negociação, e vice-versa. Em outras palavras, "states are able to adopt strategies that change key characteristics of the bargaining structure" (MCKIBBEN, 2013, p. 412). Assim, “international institutions like

\footnotetext{
${ }^{35}$ As táticas de enquadramento consistem em caracterizar um evento ou um processo em relação a um ponto de referência específico. Um exemplo concreto é a tática adotada pelo Brasil e outros países em desenvolvimento durante as discussões que culminaram na adoção da Declaração sobre TRIPS e Saúde Pública, na Conferência Ministerial de Doha, em 2001: em lugar de serem debatidas num contexto de proteção à propriedade intelectual, como tradicionalmente era feito, as patentes de medicamentos, e o seu eventual licenciamento compulsório, passaram a ser considerados como questão de saúde pública.
} 
GATT and WTO are products of negotiations in the first place and also may influence later negotiations" (ODELL, 2006, p. 11). ${ }^{36}$

Como visto, autores que privilegiam as explicações institucionais para a compreensão das negociações comerciais multilaterais têm destacado regras procedimentais, como o single undertaking e a regra do consenso, além de características da condução administrativa da OMC, como fatores relevantes para os resultados alcançados na Rodada Doha. Em contraste, e diferentemente do que ocorre em muitas interpretações da economia política, que abstraem o processo negociador, a análise das negociações internacionais proposta por Odell (2000, 2006, 2009) deixa temporariamente de considerar a influência das instituições sobre o processo e o resultado das negociações, com o objetivo, justamente, de lançar luz sobre aspectos das negociações normalmente desconsiderados pelos pesquisadores.

Além disso, como visto, no que diz respeito a este trabalho, as características institucionais mantiveram-se essencialmente constantes entre as Conferências Ministeriais de Cancun (2003) e de Hong Kong (2005), tornando improvável que fatores relacionados à instituição tenham relação de causalidade com os resultados alcançados nas duas oportunidades. Assim, em que pese o reconhecimento da endogenia entre instituição e processo negociador, e em conformidade com o proposto por Odell (2000, 2006, 2009), o foco deste trabalho serão as negociações levadas a cabo por ocasião de cada uma das duas Conferências, e não os aspectos institucionais da OMC.

\subsubsection{Conceitos centrais}

A ideia central da abordagem teórica proposta por Odell é que alterações no processo das negociações econômicas internacionais, incluindo as diferentes estratégias adotadas pelos negociadores, impactam substancialmente os resultados das negociações (ODELL, 2000, p. 2).

Odell define negociação ${ }^{37}$ como "a sequence of actions in which two or more parties address demands and proposals to each other for the ostensible purposes of reaching an agreement and changing the behaviour of at least one actor” (ODELL, 2000, p. 4). Já o processo

\footnotetext{
${ }^{36}$ A este respeito, Odell destaca: "Finnmore 1996 reports three historical cases in which an international organization shaped states' very interests and hence their behavior in negotiations and elsewhere" (ODELL, 2000, p. 200).

${ }^{37}$ O termo "negociação" é usado como sinônimo de "barganha".
} 
das negociações econômicas internacionais "refers to what finance and trade ministers and diplomats $^{38}$ as a group, joined sometimes by others, do with one another" (ODELL, 2000, p. 4). Esse processo inclui (entre outros) as estratégias que são adotadas pelos negociadores; como os mercados e as negociações influenciam um ao outro; e como as coalisões são criadas e desfeitas (ODELL, 2000).

Resultados são "the terms of a government agreement or implicit settlement (or an impasse), and not the effects official settlements may have later in markets or politics" (ODELL, 2000, p. 4). Finalmente, o contexto "involves the surrounding conditions that monetary and trade diplomats normally inherit and cannot influence much in the short run" (ODELL, 2000, p. 4), o que inclui as instituições domésticas e internacionais.

As estratégias correspondem ao conjunto de comportamentos adotados pelos negociadores com o propósito alcançar algum objetivo por meio da negociação. Táticas, por sua vez, são as ações específicas que compõem uma estratégia (ODELL, 2000).

Ao contrário de trabalhos anteriores sobre cooperação internacional baseados na teoria do jogos, aqui não se assume que as estratégias limitam-se a duas escolhas binárias. Para o autor, as estratégias à disposição dos negociadores ocupam um espectro que vai além da simples deserção ou cooperação: há desde estratégias puramente distributivas, ou "reivindicadoras de valor" (value claiming), até estratégias puramente integrativas, ou "criadoras de valor" (value creating) $(\text { ODELL, 2006) })^{39}$.

Estratégias puramente distributivas são constituídas por um conjunto de táticas que servem apenas para reivindicar ganhos ou para proteger-se da reivindicação de terceiros. Elas incluem táticas como iniciar a negociação com demandas particularmente altas; recusar todas as concessões; exagerar as suas necessidades mínimas e prioridades reais; manipular informação em

\footnotetext{
${ }^{38}$ Neste trabalho, exceto quando especificado o contrário, os termos "negociadores" e "delegações" são utilizados de forma intercambiável, e incluem os Ministros, diplomatas e outros oficiais de governo que representem os respectivos países nas Conferências Ministerais e demais reuniões de negociação.

${ }^{39}$ McKibben (2013) oferece uma classificação alternativa, com quatro categorias de comportamento negociador. No comportamento menos cooperativo (categoria 0), as táticas adotadas têm o propósito de extrair concessões de outros Estados, como nas ameaças de veto a um acordo. O segundo comportamento menos cooperativo (categoria 1) definese pela recusa em fazer concessões, frequentemente acompanhada pela demanda por concessões das contrapartes. Já as estratégias mais cooperativas (categoria 3) caracterizam-se pela disposição em aceitar o resultado demandado pela contraparte em pelo menos um dos temas centrais em negociação. Comportamento relativamente menos, mas ainda cooperativo (categoria 4) seriam as ofertas de concessões que indicam disposição dos Estados em ajustar a sua posição, embora não para aceitar o resultado preferido pela outra parte (MCKIBBEN, 2013, pp. 417-418).
} 
detrimento dos demais; "tomar como reféns" os temas de interesse dos demais; piorar a alternativa ao acordo para os demais; fazer ameaças; e impor penalidades (ODELL, 2006).

Estratégias puramente integrativas, por outro lado, são constituídas por um conjunto de táticas que buscam alcançar objetivos que não estejam fundamentalmente em conflito com os demais participantes da negociação e, assim, podem ser integradas, em alguma medida, com a finalidade de ganho mútuo. São exemplos desse tipo de tática compartilhar informações para explorar problemas ou ameaças comuns, em busca de soluções que favoreçam ambas as partes; intercambiar concessões ou recuos que possam favorecer mais de uma parte; e reenquadrar (reframe) contextualmente a questão em debate, de forma a facilitar a superação de impasses (ODELL, 2006).

Estratégias mistas-distributivas e mistas-integrativas consistem na combinação dos dois tipos de táticas (seja simultaneamente, seja sucessivamente), sendo que no primeiro caso prevalecem táticas distributivas e no segundo caso prevalecem táticas integrativas (ODELL, 2006).

Mas o que leva à adoção de uma ou outra estratégia? Segundo Odell, entre outros fatores, as negociações são influenciadas pela dinâmica dos jogos de dois níveis, apresentada na seção anterior deste capítulo: a política doméstica pode afetar, por exemplo, a credibilidade das ameaças apresentadas em uma negociação internacional; a percepção do negociador quanto às alternativas ao acordo; e a sua avaliação quanto às chances de ratificação futura (ODELL, 2000).

Além disso, como o negociador é limitado por uma racionalidade circunscrita e, portanto, age em um ambiente com informação incompleta e condicionado por limitações cognitivas, seu comportamento também é influenciado pelas suas ideias. Ele é afetado, por exemplo, por enviezamentos de julgamento, que influem nos valores que o negociador atribui às propostas apresentadas e às alternativas ao acordo (ODELL, 2000).

Finalmente, a escolha da estratégia varia por influência das condições objetivas do mercado. Assim, quanto melhor forem as alternativas de mercado para o negociador, maiores as chances de que ele adote estratégias distributivas, e menores as chances de que ele adote estratégias integrativas, e vice-versa (ODELL, 2000).

As condições objetivas do mercado afetam o ponto de resistência, ou valor de reserva, que corresponde ao que Raiffa (1982 apud PUTNAM, 1988) define como "walk-away price" do vendedor - o preço abaixo do qual o vendedor passa a preferir não fazer o negócio. Em uma 
negociação, conforme esclarecido por Lax e Sebenius (1991, p. 477), "Faced with a take it or leave it offer ${ }^{40}$, the agent should only accept prices that leave him better off than not settling”.

O ponto de resistência é definido, para cada parte, pela percepção sobre qual seria a sua melhor alternativa ao acordo negociado - BATNA ${ }^{41}$. Quanto pior a BATNA, mais baixo o ponto de resistência (ODELL, 2000). Por outro lado, quanto melhor a BATNA, maior a vantagem de uma parte diante dos demais negociadores, e mais alto o ponto de resistência. Em outras palavras, "States with a beneficial outside option have greater bargaining power than states facing costly outside options, all else constant” (MORROW, apud MCKIBBEN, 2013, p. 414). Tanto o ponto de resistência quanto a BATNA são, para Odell, variáveis cognitivas, influenciadas que são pela percepção e pelo julgamento dos negociadores (ODELL, 2000).

O conjunto de resultados possíveis localizados entre os pontos de resistência das partes negociadoras correspondem a situações em que o acordo é considerado aceitável por todos os envolvidos; esta área é denominada "zona de acordo", "zona de contrato" ou "faixa de negociação" (ODELL, 2000) ${ }^{42}$. Para que haja acordo, é necessário que essa interseção seja positiva.

Caso não haja resultados possíveis localizados entre os pontos de resistência das partes, a zona de acordo é considerada negativa. Neste caso, é possível que as partes adotem táticas distributivas (como ameaças) para mover o ponto de resistência das demais e, assim, criar uma zona positiva de acordo (ODELL, 2000).

A figura abaixo ilustra os conceitos recém-apresentados. Os eixos A e B mostram os ganhos de duas partes (Parte A e Parte B) envolvidas em uma negociação hipotética. As linhas a e b marcam os pontos de resistência de cada uma das partes. A curva $\mathbf{P}$ delimita a fronteira de possibilidades, fronteira de Pareto ou fronteira de eficiência dessa negociação ${ }^{43}$. No ponto $\mathbf{1}$, o resultado supera a BATNA para a Parte $\mathbf{A}$, mas não para a Parte $\mathbf{B}$; no ponto 2 , acontece o inverso. O ponto 6 corresponde a um resultado que, por alguma razão (tecnológica, por exemplo)

\footnotetext{
${ }^{40}$ Esta oferta pode ser tanto uma troca única quanto o último estágio de um processo de negociação com várias etapas.

${ }^{41}$ O conceito de BATNA parece ser equivalente ao de "custo de não-acordo", proposto por Putnam (1988). No momento da ratificação, este custo seria avaliado pelos atores no Nível 1, comparando-se o acordo negociado com a hipótese de ausência de acordo. O não-acordo, para Putnam, "often represents the status quo, although in some cases no-agreement may in fact lead to a worsening situation" (1988, p. 442).

${ }^{42}$ Em mais um paralelo com a abordagem proposta por Putnam (1988), a "zona de acordo" corresponderia à área em de sobreposição dos win-sets dos negociadores.

${ }^{43}$ Odell esclarece que, na prática, "negotiatiors lack neat diagrams to show them where the possibility frontier lies; the limits of the possible are hazy" (2000, p. 56).
} 
não pode acontecer. Finalmente, a área verde, onde estão localizados os pontos $\mathbf{3}, \mathbf{4}$ e $\mathbf{5}$ corresponde a resultados da negociação que superam a BATNA para ambas as Partes - são, portanto, possíveis acordos.

Figura 2. Pontos de resistência, fronteira de possibilidades e resultados

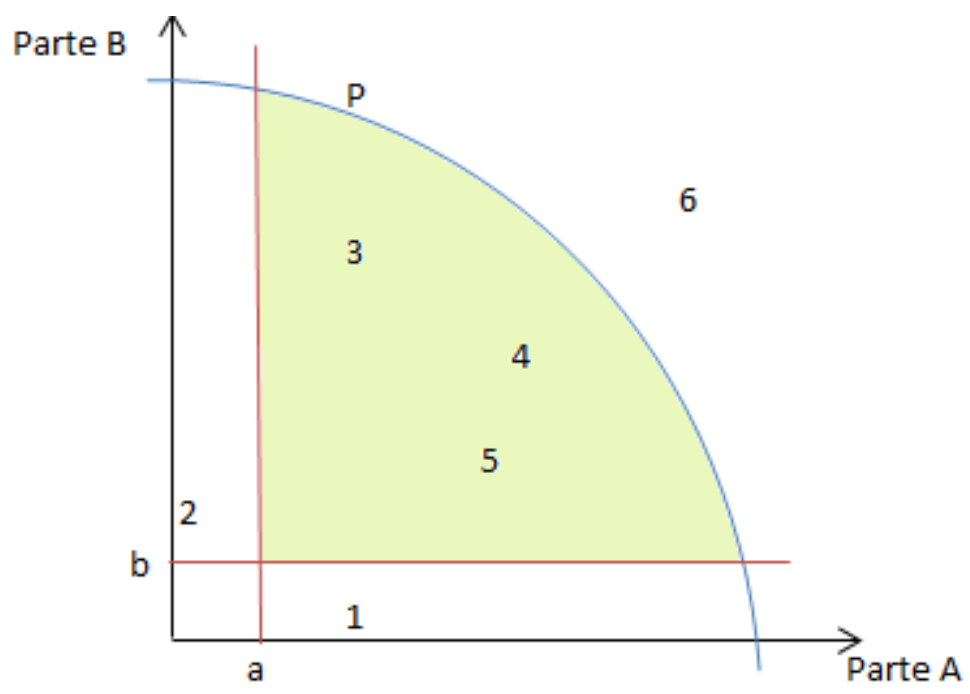

Fonte: Elaboração própria com base em Odell (2000)

Até aqui, vimos as premissas e os conceitos centrais da teoria de médio alcance proposta por John Odell (2000, 2006, 2009) para explicar as negociações econômicas internacionais. A seguir, serão apresentadas as três hipóteses que serão posteriormente aplicadas aos casos selecionados para este estudo.

\subsubsection{Hipóteses}

Em artigo de 2009 intitulado Breaking Deadlocks in International Institutional Negotiations: The WTO, Seattle, and Doha, Odell aplica as premissas e os conceitos da teoria de médio alcance por ele desenvolvida à análise de duas Conferências Ministeriais realizadas no âmbito da OMC. Especificamente, Odell busca as razões por que a Terceira Conferência Ministerial da OMC, realizada em Seattle, em 1999, e a Quarta Conferência Ministerial, realizada em Doha, em 2001, tiveram resultados opostos - a reunião realizada em Seattle terminou em impasse, enquanto a de Doha resultou na aprovação de uma Declaração e outras decisões 
ministeriais, além do lançamento de uma nova e ambiciosa rodada de negociações comerciais multilaterais.

A partir da identificação dos mecanismos causais que levaram o par de casos estudado aos diferentes resultados, Odell (2009) desenvolve três hipóteses, que relacionam a atuação de negociadores e mediadores ${ }^{44}$ e o processo de negociação, incluindo os seus resultados.

A primeira hipótese é a de que se uma parte percebe que a melhor alternativa ao acordo (BATNA) piorou, o seu negociador mudará a estratégia no sentido de reduzir as demandas, suavizar as táticas distributivas e acrescentar táticas integrativas. Em sentido inverso, a percepção de melhora na BATNA direcionará a estratégia para o sentido contrário, em média, e outras circunstâncias mentidas constantes (ODELL, 2009).

Assume-se, aqui, que cada negociador tem ao menos uma alternativa ao acordo que está sendo negociado, mesmo que seja uma alternativa pouco atraente. Como visto, a melhor alternativa ao acordo (BATNA) determinará o ponto de resistência do negociador, ou seja, o pior acordo que ele está disposto a aceitar (ODELL, 2009).

Esta hipótese seria desconfirmada pela demonstração empírica de que os negociadores, de uma forma geral, reagem a uma piora na BATNA com o uso mais intensivo de táticas distributivas (possíveis motivos para isso seriam o enviezamento contra táticas integrativas e a recusa em reconhecer a derrota) (ODELL, 2009).

A segunda hipótese é a de que as chances de superar um impasse aumentam, em média e sempre que as partes têm um objetivo comum, na medida em que as partes se afastam de políticas distributivas estritas e se aproximam de estratégias mistas-integrativas (ODELL, 2009).

Esta hipótese não prevê que táticas integrativas são melhores ou que elas sempre funcionam. Há situações em que uma parte com maior poder relativo pode ganhar mais, ao final da negociação, reforçando a utilização de táticas distributivas (utilizando ameaças, por exemplo). Mesmo nessas situações, no entanto, as chances de se chegar a um acordo serão maiores quando

\footnotetext{
${ }^{44}$ Aqui, o comportamento do Diretor-Geral da OMC e dos Chairs e facilitadores dos grupos de negociação não são considerados como parte do contexto institucional, mas como variáveis do processo de negociação (ODELL, 2009). Trata-se, cabe esclarecer, de situações em que tais atores não observam estritamente as regras institucionais - não porque agem de forma contrária a essas regras, mas porque, em muitas situações, tais regras inexistem. A informalidade e a ausência de regras relacionadas aos processos de decisão são características da OMC tratadas por Amrita Narlikar (2005). Segundo a autora, decorrem dessas características dois conjuntos de problemas: falta de transparência e previsibilidade; e sujeição da OMC a "improvisações", que, por sua vez, condicionam-se aos recursos de poder dos diferentes Membros da Organização.
} 
forem adotados elementos interativos, que reduzam as perdas ou aumentem os ganhos das demais partes envolvidas (ODELL, 2009).

Esta hipótese seria desconfirmada caso se constatasse empiricamente que situações em que estratégias puramente distributivas superam impasses são mais comuns do que situações em que estratégias mistas chegam a esse resultado (ODELL, 2009).

A terceira hipótese é a de que as chances de superar um impasse aumentam, em média, nas negociações em que há um mediador e em que se busca acordar um texto por consenso, na medida em que o mediador utiliza mais táticas inclusivas e propõe um texto negociador (draft) mais robusto, e vice-versa. (ODELL, 2009).

Esta hipótese pressupõe que partes negociadoras com interesses parcialmente conflitantes tendem a apresentar propostas que são incompatíveis e a adiar concessões. A partir de informações recebidas em confiança de todas as partes negociadoras, o mediador poderá elaborar uma proposta intermediária que atenda, tanto quanto possível, ao interesse de todos, reduzindo as barreiras subjetivas e aumentando as chances de acordo. É importante, contudo, atentar para os riscos de que a atuação do mediador seja percebida como pouco inclusiva ou enviesada, o que reduzirá as chances de acordo. (ODELL, 2009).

Segundo Odell, um draft excessivamente cauteloso, que reproduza as diferentes propostas para uma determinada questão, pode levar a que as partes "congelem" as suas posições - assim que os negociadores veem a sua redação em um documento oficial, isso é considerado uma vitória, e para que se alcance um texto de consenso é provável que vários deles tenham que abrir mão dessa conquista. Como visto na primeira parte deste capítulo, a "Teoria dos Prospectos" ensina que as pessoas têm maior disposição a correr riscos para evitar uma perda do que para alcançar um ganho. Neste caso, o risco seria o impasse e a perda, a exclusão de sua proposta de redação no texto final; o ganho seria um texto consensuado. Como são grandes as chances de resistência à eliminação de propostas, a partir de um draft cauteloso são pequenas as chances de alcançar um texto único final (ODELL, 2009).

Para Odell, uma intervenção mais ousada do mediador teria mais chances de sucesso: um único texto negociador, informal (já que não foi previamente aceito por nenhuma delegação), que cubra todos os temas necessários, seja equilibrado e garanta ganhos a todos os envolvidos. Isso incentivaria os negociadores a aceitarem o draft e fazerem concessões, de forma a não serem excluídos do processo: "Once this procedure has been announced, parties have greater incentive 
to initiate compromises themselves since otherwise the chair will take the matter out of their hands" (ODELL, 2009, p. 9, citando indiretamente Buzan, 1981).

Adicionalmente, se o mediador sugere que, com base em suas consultas confidenciais, o texto é o mais próximo possível do consenso, isso aumenta a percepção dos custos de sua rejeição, favorecendo o acordo. Caso haja um tema particularmente controverso, ele poderá ser excluído do texto, o que também favorecerá o acordo (ODELL, 2009).

Por outro lado, uma intervenção ousada corre o risco de que o draft seja rejeitado pelos negociadores. Odell ressalva que a previsão da terceira hipótese não garante que o mediador será sempre bem-sucedido, ou que as partes da negociação serão igualmente satisfeitas (ODELL, 2009).

A terceira hipótese seria desconfirmada caso fosse empiricamente demonstrado que mediadores que utilizam táticas menos inclusivas, mais cautelosas, ou evitam propor textos únicos de sua autoria associam-se a um número equivalente, ou maior, de $\operatorname{acordos}^{45}$ (ODELL, 2009).

No próximo capítulo, serão reconstruidos os acontecimentos e o comportamento das delegações e dos mediadores durante a Quinta Conferência Ministerial da OMC, realizada em Cancun, em 2003, e a Sexta Conferência Ministerial da OMC, realizada em Hong Kong, em 2005, bem como no processo de preparação para os eventos. Com o objetivo de contextualizar essas duas Conferências, também se fará uma apresentação não-exaustiva das demais Conferências Ministeriais realizadas desde a criação da OMC, tanto aquelas que antecederam o par de casos objeto desta análise, quanto as que as sucederam.

Por fim, no capítulo seguinte, as três hipóteses desenvolvidas por John Odell (2009) serão testadas por meio de sua aplicação aos casos selecionados.

\footnotetext{
$45 \mathrm{Na}$ verdade, Odell (2009, p. 9) utiliza a expressão "are associated with an equal number or better agreements" (grifo da autora). No entanto, acredito não caber aqui juízo de valor a respeito dos acordos alcançados. Busca-se, tãosomente, associar o comportamento do negociador às chances de construção de consensos.
} 


\section{Estudos de caso}

\subsection{Antecedentes (de Marraqueche a Doha)}

As Conferências Ministeriais são o mais alto órgão decisório da OMC. Elas reúnem Ministros de Estados de todos os Membros da Organização, e têm autoridade para, observados os requisitos legais, decidir sobre todos os temas cobertos pelos acordos da OMC.

Na maior parte das vezes, as Conferências Ministeriais não são realizadas em Genebra (onde fica a sede administrativa da Organização), mas em um dos países membros da OMC. Ao contrário das demais reuniões em Genebra, que são organizadas pelo Diretor-Geral (DG) da OMC e pelo Presidente, ou Chair, do Conselho Geral, quem conduz os trabalhos durante as Conferências Ministeriais é o Ministro de Estado resposável pela política comercial ou pelas relações exteriores (ou equivalente) do país que sedia a Conferência (NARLIKAR, 2004).

À época do GATT, as Conferências Ministeriais eram normalmente convocadas apenas para o lançamento de Rodadas de negociação (NARLIKAR, 2004). A partir da criação da OMC, elas passaram a se reunir pelo menos uma vez a cada dois anos ${ }^{46}$. Assim, desde a assinatura do Acordo de Marraqueche e da consequente criação da OMC, em 1995, foram realizadas dez Conferências Ministeriais, conforme o quadro abaixo:

Quadro 1. Conferências Ministerias da OMC 1995 - 2015

\begin{tabular}{|c|c|c|}
\hline Conferência Ministerial & Lugar & Data \\
\hline Primeira & Cingapura & 9 a 13 de dezembro de 1996 \\
\hline Segunda & Genebra & 18 a 20 de maio de 1998 \\
\hline Terceira & Seattle & 30 de novembro a 3 de dezembro de 1999 \\
\hline Quarta & Doha & 9 a 13 de novembro de 2001 \\
\hline Quinta & Cancun & 10 a 14 de setembro de 2003 \\
\hline Sexta & Hong Kong & 13 a 18 de dezembro de 2005 \\
\hline Sétima & Genebra & 30 de novembro a 2 de dezembro de 2009 \\
\hline
\end{tabular}

${ }^{46} \square$ Acordo de Marraqueche (Acordo Constitutivo da OMC), artigo IV.1. Como se verá adiante, as negociações da Rodada Doha foram suspensas em julho de 2006; em 2007, pela primeira e única vez, a Conferência Ministerial prevista não se realizou (VANGRASSTEK, 2013). 


\begin{tabular}{|c|c|c|}
\hline Oitava & Genebra & 15 a 17 de dezembro de 2011 \\
\hline Nona & Bali & 3 a 6 de dezembro de 2013 \\
\hline Décima & Nairobi & 15 a 18 de dezembro de 2015 \\
\hline
\end{tabular}

Fonte: WTO, [s.d.]

Na Primeira Conferência Ministerial, realizada em Cingapura, em 1996, discutiram-se temas como a relação entre comércio e a proteção ao meio ambiente e ao trabalho, além de questões sobre investimentos, concorrência, compras governamentais e facilitação de comércio estes últimos quatro temas posteriormente tornaram-se conhecidos como "Temas de Cingapura". Durante a Conferência, emergiu uma divisão clara entre países desenvolvidos (PDs) e países em desenvolvimento (PEDs), com aqueles defendendo, em linhas gerais, o aprofundamento da discussão dos "Temas de Cingapura", além da relação entre comércio e meio ambiente e comércio e trabalho; e estes demandando, principalmente, a garantia de tratamento preferencial aos países de menor desenvolvimento relativo (PMDRs) ${ }^{47}$ (VANGRASSTEK, 2013)

A Segunda Conferência Ministerial, realizada em Genebra, em 1998, teve propósito mais comemorativo do que negociador - completavam-se 50 anos da criação do GATT (VANGRASSTEK, 2013). Com efeito, a Declaração Ministerial ${ }^{48}$ adotada ao final da Conferência teve como propósito ressaltar a importância do sistema multilateral de comércio e reafirmar os compromissos e avaliações realizados em Cingapura (WORLD TRADE ORGANIZATION [WTO], 1998a). Ainda como resultado da Conferência, o Conselho Geral da OMC foi orientado a estabelecer um programa de trabalho compreensivo para examinar as questões comerciais relacionadas ao comércio eletrônico global (WTO, 1998b).

Apenas nos preparativos para a Terceira Conferência Ministerial, realizada em 1999, em Seattle, passou-se a considerar a possibilidade de se lançar uma nova Rodada de negociações, então denominada Rodada do Milênio (Millenium Round). Os desafios a serem superados eram, contudo, evidentes. Era previsível que os protestos contra a globalização e a liberalização comercial, já presentes em Cingapura e Genebra, se intensificassem. Havia, além disso, uma grande divisão entre os Membros em relação à conveniência do lançamento de uma nova

\footnotetext{
${ }^{47}$ Definir PDs, PEDs e PMDRs.

48 Os textos das Declarações e Decisões Ministeriais podem ser acessados aqui: https://www.wto.org/english/thewto_e/minist_e/min_declaration_e.htm.
} 
Rodada: mesmo entre aqueles que defendiam, antes de Seattle, o lançamento de uma Rodada nos moldes da bem-sucedida Rodada Uruguai, havia posições divergentes quanto a quais deveriam ser os objetivos das negociações. Finalmente, o longo e conturbado processo de seleção do novo DG da OMC (em substituição ao italiano Roberto Ruggiero), que resultou na divisão do exercício do mandato de seis anos entre o australiano Mike Moore e o tailandês Supachai Panitchpakdi, dificultou a preparação para a Conferência (VANGRASSTEK, 2013).

Como desejado pelo grande número de manifestantes anti-globalização que compareceu a Seattle, a Terceira Conferência Ministerial terminou em impasse. Não apenas não houve o lançamento de uma nova Rodada, mas os Ministros deixaram a reunião sem consenso sequer em relação ao comunicado, usual nesses casos, que deveria conter o compromisso de trabalho futuro conjunto (ODELL, 2009).

O fracasso em Seattle fez com que se questionasse a viabilidade de uma organização como a OMC, encarregada da supervisão de um sistema global constituído por número tão elevado de atores, e responsável por uma diversidade tão grande de temas. A eficiência da OMC também foi questionada, tendo em vista a exigência do consenso para as decisões da Organização (WTO, 2003a).

O colapso da reunião de Seattle, no entanto, serviu como aprendizado. O primeiro passo para superá-lo, conforme ressalta VanGrasstek, foi atribui-lo não às manifestações contrárias à Conferência, mas à preparação inadequada:

While the chaos in the streets did not make things any easier, it was the lack of preparation inside the WTO itself that caused the greatest damage. "The work hadn't been done," Director-General Mike Moore would later acknowledge, "and when we got to Seattle we were essentially just too far apart." (2013, p. 377)

Uma das principais críticas à condução do processo negociador antes e durante a Conferência de Seattle foi a de que ele havia sido pouco inclusivo e pouco transparente. Assim, no intervalo entre a Terceira e a Quarta Conferências Ministeriais buscou-se alterar essa percepção e reforçar a confiança entre os negociadores.

Em Genebra, a maior parte das reuniões preparatórias para a Ministerial de Doha passou a ser aberta ao conjunto dos Membros, e mesmo as reuniões restritas passaram a ser reportadas a todos, sendo dada oportunidade aos não-participantes de manifestarem suas posições (ODELL, 2009). Da mesma forma, o draft que serviria de base à Declaração Ministerial de Doha foi elaborado pelo então Chair do Conselho Geral, Stuart Harbinson, de Hong Kong, a partir da compilação de tópicos sugeridos pelos Membros, em uma dinâmica que, no geral, foi 
reconhecida como bottom-up ${ }^{49}$ (VANGRASSETK, 2013; ODELL, 2009). Ao mesmo tempo, o DG Mike Moore buscou aproximar-se dos representantes dos PEDs e dos PMDRs (VANGRASSETK, 2013).

A par das discussões em Genebra, realizaram-se também, como preparação para a Quarta Conferência Ministerial, duas reuniões mini-ministeriais ${ }^{50}$, uma na Cidade do México, em agosto, e outra em Cingapura, em outubro. Essas reuniões deram aos Ministros a oportunidade de se conhecerem pessoalmente e se aproximarem, aumentando a confiança de que a nova Rodada poderia ser lançada na Conferência Ministerial de Doha (ODELL, 2009).

Com efeito, VanGrasstek ressalta que, além da preparação mais cuidadosa e de partir de um draft de Declaração Ministerial mais conciso e de texto menos controverso, os Ministros chegaram a Doha mais dispostos a negociar - muito embora, há de se destacar, as diferenças substantivas permanecessem: "[d]ivisions remained among the members over the same issues that had dogged them since Singapore, but there was now a greater willingness on the part of key players to make accommodations and trade-offs" (2013, p. 401).

Os atentados de 11 de setembro de 2001, dois meses antes da realização da Conferência, mesmo que não tenham sido determinantes (ODELL, 2009), certamente contribuíram para a boa disposição dos negociadores, particularmente os EUA. Nesse sentido, VanGrasstek ressalta:

In the short term, these events gave the United States and its WTO partners an additional rationale for launching a round, and elevated its importance to the United States from desirable to indispensable. This was a time when "... or else the terrorists win" became a predicate appended to all manner of objects in public policy, and "we need to launch a new round in the WTO ..." was one of them. Within days of the terrorist attacks, US Trade Representative Robert Zoellick advanced the argument that multilateral trade liberalization was a weapon in the war on terror (2013, p. 399, grifos da autora)

Mesmo com a boa disposição dos negociadores, o consenso de Doha foi concluído nas últimas horas da Conferência. Houve concessões importantes por parte dos EUA, que, após admitirem o reexame das regras sobre antidumping, subsídios e medidas compensatórias, concordaram com uma declaração em separado relacionando o Acordo sobre Aspectos dos

\footnotetext{
49 Não há consenso de que o processo de elaboração dos drafts para a Conferência de Doha foi inclusivo e transparente. Wolfe, por exemplo, afirma: "Developing countries claimed that they were not 'heard' in the hundreds of hours of pre-Doha meetings because they could not see their ideas in the text, even in square brackets" (WOLFE, 2011).

${ }^{50}$ A respeito da designação "mini-ministerial”, VanGrasstek esclarece: "The prefix "mini” does not connote trivial, but instead one that is held out of the usual sequence of full-dress ministerials that are supposed to take place every two years. Two aspects of this meeting were far from mini: at nine days, it was about twice as long as the typical biennial ministerial conference, and expectations for a breakthrough were higher than at any other event in the round." (2013, p. 448).
} 
Direitos de Propriedade Intelecutal Relacionados ao Comércio (Acordo TRIPS ${ }^{51}$ ) e Saúde Pública, demandada pelos PEDs. A UE também recuou nos últimos momentos, e admitiu que a Declaração Ministerial mencionasse o objetivo de eliminar os subsídios agrícolas à exportação. Finalmente, já durante a plenária de encerramento, obteve-se a concordância da Índia, que aceitou a inclusão dos "Temas de Cingapura", com a ressalva de que o lançamento das negociações nestes temas ocorreria apenas com base em um "consenso explícito" entre os Membros da OMC.

Além desses recuos estratégicos (VANGRASSTEK, 2013), o recurso à chamada "ambiguidade construtiva", tradicional desde os tempos do GATT, foi fundamental para o resultado positivo em Doha. As decisões foram redigidas de forma a contemplar a diversidade de posicionamentos entre os Membros, ressaltando as complementaridades e evitando antecipar o resultado das negociações - a prioridade era assegurar o lançamento da nova Rodada de negociações, batizada pelo DG Mike Moore de Doha Development Agenda ${ }^{52}$ (Agenda para o Desenvolvimento de Doha). Mais uma vez, é VanGrasstek quem esclarece:

The objective here was to get past the immediate problem of launching the round. It would then be the task of the negotiators to find the trade-offs and compromises that would allow them to patch up the apparent contradictions in the marching orders that the ministers gave them (2013, p. 397).

O resultado positivo em Doha aliviou os temores de que a OMC não fosse viável ou eficiente e elevou a confiança no sistema multilateral de comércio. Para os PDs, a possibilidade de maior acesso a mercados para seus produtos representava uma ferramenta importante na busca pelos objetivos de desenvolvimento. Para o restante do mundo, em um momento de incerteza política e econômica, o sucesso no lançamento da Rodada Doha evidenciou que uma estrutura multilateral é, sim, capaz de resolver problemas globais (WTO, 2003a).

A convergência alcançada na Quarta Conferência Ministerial, entretanto, não se projetou sobre as discussões que se seguiram. Nesse sentido, Barton et al. ressaltam: "While the Doha Round of trade negotiations was succesfully launched, the negotiations almost immediately deadlocked along North-South lines” (2006, pp. 1-2). Com efeito, a falta de acordo entre questões que opõem os dois grupos de países, como se verá, levou o chanceler mexicano Sr. Luis Ernesto

\footnotetext{
${ }^{51}$ Explicar Acordo TRIPS

${ }^{52}$ As Declarações Ministeriais e outras decisões adotadas ao final da Conferência Ministerial de Doha podem ser encontradas em http://www.wto.org/english/thewto_e/minist_e/min01_e/min01_e.htm (último acesso em $30 / 10 / 2014)$.
} 
Derbez a encerrar a Conferência seguinte antes do previsto, e sem que fosse adotada uma Declaração Ministerial.

\subsection{Conferência de Cancun}

A Quinta Conferência Ministerial da OMC foi realizada em Cancun, no México, entre 10 e 14 de setembro de 2003. A reunião havia sido concebida como uma "revisão de meio período" da Rodada Doha, que originalmente tinha a previsão de ser concluída em 2005 (VANGRASSTEK, 2013). Além de avaliar o progresso alcançado nos dois anos desde a Conferência Ministerial de Doha, na reunião de Cancun dever-se-ia definir como as negociações seriam conduzidas dali por diante. Nesse sentido, Robert Wolfe ressalta:

The fifth ministerial in Cancun (2003) had been intended to ensure that a balanced but ambitious package is possible so that the round can conclude at a subsequent meeting as a Single Undertaking (...) (WOLFE, 2004, pp. 575-576)

Dito de outra forma, "Cancun should pave the way for timely DDA ${ }^{53}$ conclusion", como destacado à época pelo então Diretor-Geral da OMC, o tailandês Supachai Panitchpakdi (2003, p.1).

Em seu statement na sessão de abertura da reunião, Pascal Lamy, então Comissário para o Comércio da UE, tratou da missão dos negociadores presentes à Quinta Conferência Ministerial, ressaltando o caráter controverso da maior parte dos temas em que seria necessário avançar: "But what do we have to do specifically in Cancun? To put it simply, we need to make practical progress on the series of tough issues we identified in the Doha declaration." (LAMY, 2003a, p.2).

A diferença de posições nos principais temas a serem tratados em Cancun também foi ressaltada, na mesma sessão de abertura, pelo uruguaio Pérez del Castillo, então Chair do Conselho Geral da OMC:

I should have liked nothing better than to submit to the Ministerial Conference a document that met with consensus from everyone. But you are aware that this has been impossible and that convergence or directions on crucial issues have not emerged to guarantee a new text leading to greater consensus than the document I am placing before you now (DEL CASTILLO, 2003).

Durante o processo de preparação para a Conferência, em Genebra, Del Castillo havia preparado dois drafts de Declaração Ministerial. O primeiro deles, circulado em 18 de julho de 2003, foi elaborado sob responsabilidade do Chair (ou seja, não era um texto acordado). Ele

\footnotetext{
${ }^{53}$ Doha Development Agenda (Agenda de Desenvolvimento de Doha).
} 
continha muitas lacunas e refletia, como apontado pelo próprio Chair do Conselho Geral, a ausência de resultados concretos, os vários prazos não atendidos e a divergência significativa de posições desde a Conferência de Doha (DEL CASTILLO, 2003). Em seu statement inicial, Del Castillo reconheceu que, à época da elaboração do primeiro draft (ou seja, a menos de dois meses da Conferência) "it had not been possible to start a real negotiating process, particularly on key issues for this Round, such as Agriculture" (DEL CASTILLO, 2003).

O segundo draft foi elaborado por Del Castillo em "cooperação estreita" com o DiretorGeral Supachai, e foi circulado em agosto de 2003 (a poucos dias, portanto, do início da reunião em Cancun) (WTO, 2003b). O draft foi acompanhado de uma carta de apresentação que ressaltava que, embora o documento resultasse de consultas "longas e intensivas", ao longo de muitas semanas, novamente não se tratava, dadas as divergências persistentes, de um texto acordado; e que muitas das propostas apresentadas pelos Membros não haviam sido incorporadas. Sendo assim, mais que um texto de consenso, o draft deveria servir como uma "ferramenta útil" para as discussões em Cancun. Finalmente, a carta detalhava as diferenças que afastavam os negociadores nos temas centrais a serem tratados na Quinta Conferência Ministerial (WTO, 2003c).

Tanto o processo de elaboração dos drafts quanto o seu resultado foram reprovados por organizações da sociedade civil. Logo após a divulgação do segundo draft, entidades como Oxfam, Third World Network, Public Services International (PSI) e Focus on the Global South afirmaram que o texto era "a clear step in the wrong direction" (THIRD WORLD NETWORK [TNW], 2003, p.1). Goh Chien Yen, da organização Third World Network, teria criticado o processo de submissão de textos sob responsabilidade do Chair e o fato de o texto não refletir as diferentes posições (TNW, 2003).

Inicialmente, não havia a previsão de realizar uma reunião do Conselho Geral para avaliação do draft que seria submetido aos ministros em Cancun. A decisão de convocá-la ocorreu apenas após PEDs criticarem a falta de oportunidade para manifestarem suas visões e adotarem, ou revisarem, o draft (HOMEKU, 2003). Em sua reação inicial à segunda versão do draft, tanto PDs quanto PEDs criticaram o texto. O Brasil, por exemplo, teria dito que o texto era fundamentalmente defeituoso; a UE o teria considerado "desbalanceado" e os EUA, entre outros, notaram que as suas posições não haviam sido adequadamente refletidas (BRIDGES, 2003a). 
Chegou-se a questionar se o draft do Chair deveria realmente servir de base para as negociaçoes (BRIDGES, 2003b).

Ao informar que, a despeito das numerosas críticas, encaminharia o draft, sob sua responsabilidade, para discussão na Conferência, Del Castillo afirmou que o processo preparatório em Genebra havia-se encerrado e que as grandes divergências que permaneciam poderiam ser superadas apenas no nível político, pelos ministros que participariam da reunião em Cancun (BRIDGES, 2003a).

Dentre os temas controversos na agenda da Conferência, o principal era Agricultura, "undoubtedly the core issue of the Doha Round", como destacado por Luis Ernesto Derbez, chanceler mexicano e Chair da Conferência Ministerial de Cancun (DERBEZ, 2003). De acordo com o mandato de Doha, discutir-se-ia em Cancun a abertura dos mercados agrícolas, particularmente dos PDs, por meio da eliminação progressiva de todas as formas de subsídio à exportação e da redução substancial dos subsídios domésticos e das barreiras tarifárias (os denominados três pilares das negociações em Agricultura). Para Derbez (2003), os resultados obtidos em Cancun nas demais áreas dependeriam, em grande medida, do que fosse alcançado nas negociações em Agricultura.

No mesmo sentido, ressaltando a relevância do tema não apenas para Cancun, mas também, em sentido mais amplo, para a Rodada, Supachai Panitchpakdi destacou:

There can be no doubt that an ambitious result on agriculture modalities would set in train a powerful momentum across the board and significantly improve the chances of our finishing a successful round on schedule (PANITCHPAKDI, 2003).

De um lado, o tema era de interesse ofensivo dos países com grande produção e competitividade na exportação de produtos agrícolas; tratava-se, principalmente, de PEDs, como Brasil, Argentina, Colômbia e África do Sul, mas também de PDs como Austrália e Canadá. De outro lado, PDs como EUA, UE e Japão, por adotar políticas robustas de apoio à produção e à exportação de produtos agrícolas, bem como barreiras tarifárias que protegiam seus mercados da produção agrícola estrangeira, eram contrários a avanços nessa área.

Um mês antes da Conferência de Cancun, em 13 de agosto de 2003, Estados Unidos e União Europeia haviam apresentado uma proposta conjunta sobre a matéria. Como ressaltado por Carvalho (2010), a proposta era pouco ambiciosa em relação ao que vinha sendo discutido desde o lançamento da Rodada; era, em outras palavras, "weak and watered down relative to previous proposals discussed in Geneva" (CHO, 2004, p. 227). Com efeito, ela representava um recuo em diversos aspectos: mantinha os subsídios à exportação da UE e o programa norte-americano de 
créditos para exportação; conservava limites altos para gastos com subsídios domésticos com impacto negativo no comércio internacional; propunha a utilização de uma fórmula mista (blended formula) que não atendia às demandas de cortes tarifários dos países em desenvolvimento; e propunha alterar a cláusula de Tratamento Especial e Diferenciado (que concedia tratamento mais favorável aos PEDs) ao defender que "regras e disciplinas necessitarão ser ajustadas para os países exportadores líquidos de alimentos significativos'" (CARVALHO, 2010, p. 422).

Para Blustein,

Rather than providing a text that could be used as the basis for negotiation at Cancun among all WTO members, Washington and Brussels were mainly showing concern for the sensitivities of their own agriculture lobbies. Indeed, some key elements of the paper made it look like an unholy bargain in which each big power was giving the other licence to engage in the practices that everyone else found most offensive (BLUSTEIN, 2009, pp. 141-142).

Alegando, justamente, que o texto conjunto dos EUA-UE atendia apenas aos interesses internos desses dois Membros da OMC e excluía, portanto, os interesses dos PEDs, Brasil e Índia prepararam uma contraproposta, que foi apresentada em 2 de setembro de 2003, ainda antes da Conferência. A contraproposta, intitulada Agriculture - Framework Proposal, era bastante detalhada e foi subscrita, além do Brasil e da Índia, por mais 18 países em desenvolvimento $(\text { WTO, 2003d })^{54}$.

Formava-se, assim, o G20 (CARVALHO, 2010), também denominado G21 (AMORIM, 2003) ou G22 (NARLIKAR, 2004) - o nome variava conforme a flutuação nas adesões ao grupo. A coalizão era, sem dúvida, representativa: reunia países que correspondiam à metade da população e a 63\% dos agricultores do mundo (AMORIM, 2003). Chamava a atenção, outrossim, a heterogeneidade do grupo: estavam lado a lado tanto países com tradicional interesse ofensivo em Agricultura, interessados na abertura dos mercados agrícolas dos países desenvolvidos (como Brasil e Argentina), quanto países com interesse defensivo, mais preocupados com a proteção de seus mercados domésticos, notadamente os setores de agricultura de subsistência (como a Índia) (CARVALHO, 2010; NARLIKAR; WILKINSON, 2004).

A proposta do G20 (nome com que o grupo se tornou mais conhecido) propunha, nos três pilares das negociações em Agricultura, o retorno aos objetivos da Declaração de Doha (CARVALHO, 2010, p. 425). A proposta incluía, entre outros, a redução substantiva dos

\footnotetext{
${ }^{54}$ Subscreveram o documento WT/MIN(03)W/6 (previamente circulado como JOB(03)/162Rev.1) África do Sul, Argentina, Bolívia, Brasil, Chile, China, Colômbia, Costa Rica, Cuba, Equador, El Salvador, Filipinas, Guatemala, Índia, México, Paquistão, Paraguai, Peru, Tailândia e Venezuela (WTO, 2003d).
} 
subsídios domésticos distorcivos adotados pelos países desenvolvidos; em acesso a mercados, a adoção de uma blended formula para a redução tarifária em PDs e melhoria substancial no acesso a mercado para todos os produtos, bem como acesso a tarifa zero (duty-free) para todos os produtos tropicais e outros produtos representativos exportados pelos PEDs; e, finalmente, o compromisso de eliminação, em um prazo definido, de todos os subsídios à exportação. Mais adiante veremos como este e outros temas foram negociados durante a Conferência.

Adicionalmente, era evidente o dissenso nas discussões de Acesso a Mercados em Bens Industriais (Non-Agricultural Market Access - NAMA). No final de Agosto, UE, EUA e Canadá apresentaram uma proposta ambiciosa na matéria, que previa redução tarifária global substancial. A proposta foi, no entanto, rejeitada pelos PEDs, relutantes em aceitar prazos ou a extensão de cortes tarifários em NAMA antes que houvesse progresso nas negociações em Agricultura (BRIDGES, 2003b).

Ao lado de Agricultura e NAMA, outro item controverso da agenda em Cancun eram os chamados "Temas de Cingapura" - comércio e investimentos, comércio e políticas de concorrência, transparência em compras governamentais e facilitação de comércio. Como visto anteriormente, tratava-se de matéria demandada pelos PDs, notadamente a UE, seguida pelo Japão e pela Coreia do Sul, cuja inclusão na agenda de Doha havia sido aceita pela Índia sob a condição de que qualquer decisão sobre o lançamento de negociações ocorreria apenas com base em “consenso explícito" dos Membros da OMC. No entendimento da Índia, a expressão exigiria aprovação desse lançamento por meio de uma votação nominal - "a notable departure from the usual norms of WTO diplomacy", ressaltou VanGrasstek (2013).

Em seu statement inicial em Cancun, Arun Jaitley, ministro indiano do Comércio, Indústria, Lei e Justiça, destacou as divergências entre os Membros quanto aos "Temas de Cingapura": "It is our assessment and that of many other countries as well that there are significant and deep differences in views of members on many elements of these issues." (JAITLEY, 2003, p.3). Já Pascal Lamy ressaltou, também ao início da reunião, a compreensão e a flexibilidade demonstradas pela UE visando ao lançamento das negociações desses temas em Cancun; os europeus, segundo ele, estavam dispostos a ouvir as preocupações dos demais Membros (LAMY, 2003a).

Os EUA tinham uma posição ambivalente na matéria, já que tinham defendido uma redução na ambição das discussões em compras governamentais (que passaram de acesso a 
mercados para transparência) e preocupavam-se com a possibilidade de que as discussões em concorrência terminassem por afetar negativamente a legislação doméstica de antidumping, muito cara aos norte-americanos (VANGRASSTEK, 2013).

Um quarto tema controverso contrapunha, uma vez mais, PEDs e PDs: conforme submissão apresentada em abril de 2003, quatro países africanos com grande dependência das exportações de Algodão - Benin, Burkina Faso, Mali e Chade, integrantes do grupo denominado Cotton 4 - demandavam o fim dos subsídios ao algodão no prazo de três anos, além do pagamento de compensação, no montante de 250 milhões de dólares por ano, pelos impactos negativos já causados às suas exportações (BLUSTEIN, 2009).

Tratava-se de tema novo, que não integrava o mandato negociador de Doha. A iniciativa, revela Paul Blustein, havia surgido de uma sugestão feita no início do ano por Nicholas Imboden, ex-negociador-chefe para o comércio da Suíça e em 2003 diretor de uma organização nãogovernamental (ONG) baseada em Genebra (BLUSTEIN, 2009). Os países desenvolvidos, e os EUA em particular (com seus pesados subsídios aos cotonicultores da região sul do país), eram o principal alvo das reclamações dos africanos.

Em contraste com os temas anteriores, em que não foi possível alcançar posições convergentes durante a preparação para a Quinta Conferência Ministerial, os Membros lograram chegar ao acordo em outra matéria polêmica antes da reunião de Cancun: a implementação do Parágrafo 6 da Declaração sobre TRIPS e Saúde Pública, que tratava da situação dos países com pouca ou nenhuma capacidade de produção de medicamentos, aos quais não era possível fazer uso efetivo do licenciamento compulsório previsto no Acordo TRIPS. A questão foi resolvida, do ponto de vista legal, nas vésperas da Quinta Conferência Ministerial, com a adoção pelo Conselho Geral da OMC da chamada Decisão de 30 de Agosto de 2003, que permitia a importação de medicamentos sob licenciamento compulsório de terceiros países (WTO, 2003e).

Para Del Castillo e Supachai, o acordo em TRIPS e Saúde Pública era um evento histórico e significativo; "evidence that the WTO system is working, and can produce important results on critical issues of particular interest to developing countries" (DEL CASTILLO; PANITCHPAKDI, 2003, p.1). Para o Chair do Conselho Geral e o Diretor-Geral da OMC, a 
Decisão de 30 de Agosto daria mais confiança aos representantes presentes em Cancun para lidar com os desafios nas outras áreas ${ }^{55}$ (DEL CASTILLO; PANITCHPAKDI, 2003).

De todo modo, ao iniciar-se a Conferência de Cancun, percebia-se, no conjunto dos temas que compunham a agenda da reunião, uma clivagem clara entre as posições dos PDs e PEDs: "The stage was set at Cancun for a North-South smackdown" (BLUSTEIN, 2009, p. 147).

De fato, na abertura da Conferência, Celso Amorim, chanceler brasileiro, ressaltou que aquela era a oportunidade de aproximar a OMC das necessidades e dos desejos daqueles que, até então, haviam ocupado as margens do sistema:

We have waited for many years for this chance to redress the shortcomings of previous Rounds. We now have it in our hands. We, in the G-21, are organized for that purpose. We stand united, we will remain united. We sincerely hope that others will hear our message and, instead of confronting us or trying to divide us, will join forces in our endeavour to inject new life into the multilateral trading system (AMORIM, 2003, p.2).

Em sintonia com o chanceler brasileiro, Arun Jaitley declarou estar confiante que, sob a orientação do Chair da Conferência, "we will collectivelly find solutions to the various contentious issues in such a manner that the final declaration reflects the needs and aspirations of developing countries." (JAITLEY, 2003, p.4).

Antevendo os obstáculos que enfrentaria na reunião, Pascal Lamy defendeu que se deveria evitar reproduzir em Cancun a atmosfera de confronto Norte-Sul típica dos anos 1970 e 1980: "It would be a great mistake to see the situation this way, and at odds with the reality. For there are many lines of division in our debates, many south positions, many north positions." (LAMY, 2003a, p.3). Como se verá a seguir, o apelo de Lamy foi inútil.

\subsubsection{O dia-a-dia da Conferência de Cancun}

\subsubsection{Primeiro dia-Quarta-feira, 10 de setembro de 2003}

Já na sessão de abertura da reunião, o Chair da Conferência, o chanceler mexicano Luis Ernesto Derbez, informou aos presentes que havia convidado cinco Ministros para atuarem como facilitadores, coordenando Grupos de Trabalho temáticos.

\footnotetext{
${ }^{55}$ Além desses temas centrais, que serão o foco deste trabalho, foram negociadas em Cancun outras matérias, como Serviços e questões horizontais relacionadas à implementação das obrigações resultantes da Rodada Uruguai e ao Tratamento Especial e Diferenciado a países em desenvolvimento.
} 
Para Agricultura, foi indicado o Ministro de Comércio e Indústria de Cingapura, George Yeo Yong-Bom; para Acesso a Mercados em Bens Industriais (NAMA), o Secretário de Finanças de Hong Kong, Henry Tang Ying-yen; para questões relacionadas ao Desenvolvimento, o Ministro do Comércio e Indústria de Quênia, Mukhisa Kituyi; para os "Temas de Cingapura”, o Ministro do Comércio do Canadá, Pierre Pettigrew; para "Outros Assuntos” (temas incluídos no draft de Declaração Ministerial e não cobertos pelos demais Grupos de Trabalho, como Serviços, Regras e Indicações Geográficas), o Ministro do Comércio Exterior e da Cooperação Internacional da Guiana, Clement Rohee (WTO, 2003f).

Um sexto facilitador foi apresentado na manhã seguinte, para o tema do Algodão: o Diretor-Geral da OMC, Supachai Panitchpakdi. Conforme posteriormente revelado por Supachai, ele foi designado como facilitador porque ninguém havia se disponibilizado a assumir o Grupo de Trabalho. A esse respeito, Paul Blustein afirma:

Nobody else had agreed to do it; Supachai did, partly because someone had to, and partly, some Secretariat officials suspected, because he was flattered that he was finally being asked to do something meaningful (BLUSTEIN, 2009, 150 - grifo no original).

Para esse autor, conquanto fosse bem educado e agradável, faltava a Supachai a habilidade de confrontar (head-banging skills) necessária ao cargo. Blustein ressalta que, embora normalmente o Diretor-Geral da OMC desempenhasse um papel crucial nas Conferências Ministeriais, liderando as discussões em Green Rooms $^{56}$ e outras reuniões importantes, este não foi o caso de Supachai em Cancun; o Chair Derbez viu-se obrigado a assumir a maior parte dessas responsabilidades (BLUSTEIN, 2009).

Se por um lado os EUA criticaram a escolha de Supachai para facilitador no tema do Algodão, alegando que ela colocava em dúvida a imparcialidade do Diretor Geral (que, na véspera, havia defendido que a iniciativa africana tinha "fortes méritos morais e econômicos"), também os países do Cotton 4 e seus apoiadores acabaram mostrando-se insatisfeitos com a escolha, e, dois dias depois, acusaram Supachai de propor um texto que, em sua avaliação, aproximava-se excessivamente da posição norte-americana (VANGRASSTEK, 2013).

Estabeleceu-se que os Grupos de Trabalho seriam abertos à participação de todos e se reportariam todas as manhãs às reuniões de Chefes de Delegação, que seriam abertas à participação de todos os Membros - segundo o Chair Derbez, a função das reuniões de Chefes de

\footnotetext{
${ }^{56}$ O nome Green Room vem dos primórdios do GATT, quando o Diretor-Geral costumava convocar reuniões informais das partes interessadas sobre um determinado assunto em sua sala de reuniões, que era conhecida por ter a cor verde (WOLFE, 2011). O termo hoje se refere a qualquer reunião de um pequeno número de Membros que tenha sido convocada por um Chair ou pelo Diretor-Geral (NARLIKAR, 2006)
} 
Delegação era garantir transparência e inclusão de todos no processo (WTO, 2003f). Os facilitadores poderiam, ademais, promover reuniões entre países e grupos regionais, além de “confessionários” (reuniões bilaterais) com Membros-chaves (BRIDGES, 2003c).

Ainda no primeiro dia, foi apresentada em Plenário a demanda do Cotton 4. Na véspera, em 9 de setembro, o Representante para o Comércio dos Estados Unidos, Robert Zoellick, havia proposto aos países do Cotton 4 que diversificassem sua produção para incluir, além do algodão, têxteis, que poderiam beneficiar-se de acesso preferencial sob o African Growth and Opportunity $A c t^{57}$. A proposta dos EUA foi percebida por muitos como evidência de que os norte-americanos não levavam a sério a demanda dos países africanos (VANGRASSTEK, 2013).

Já na reunião do dia 10 de setembro, Mali defendeu uma decisão antecipada (early harvest) na matéria; Chade frisou a necessidade de resultados concretos para a manutenção da credibilidade do sistema multilateral de comércio; e outros países africanos, como Camarões e Senegal, apoiaram a iniciativa do Cotton 4, afirmando que toda a região era negativamente afetada pelos subsídios ao algodão. Canadá, Austrália, Argentina, África do Sul, Bangladesh e Índia, além da UE, também acolheram bem a iniciativa. O Diretor-Geral e facilitador Supachai afirmou que os países africanos não demandavam preferências, mas o fim de distorções, e instou os Ministros a considerarem a iniciativa com seriedade (BRIDGES, 2003c).

$\mathrm{Na}$ mesma reunião, os EUA reiteraram que apoiavam a eliminação dos subsídios e a redução das barreiras tarifárias em geral, tanto para produtos agrícolas quanto industriais; chamaram atenção para outros fatores que poderiam causar a queda nos preços do algodão (recessão econômica, competição com fibras artificiais etc); e propuseram olhar para toda a cadeia de produção - fibra, têxteis, vestuário - e propor medidas personalizadas para elevar a demanda por algodão (BRIDGES, 2003c). A UE, por sua vez, afirmou que sua produção e exportação eram pequenas demais para impactar os preços globais do algodão; apoiou elementos comerciais da proposta africana; e comprometeu-se a contribuir para que se acordasse uma solução (BRIDGES, 2003c).

Quanto à Agricultura, comentava-se nos bastidores, já no primeiro dia da Conferência, que EUA e UE estariam tentando reduzir o apoio e evitar novas adesões ao G20. Enquanto a UE

\footnotetext{
${ }^{57}$ Programa do Governo dos EUA promulgado em maio de 2000 e, atualmente, com validade até 2025. Ele oferece preferências tarifárias a produtos de países da região subsaariana que cumpram com determinado pré-requisitos, como eliminação de barreiras comerciais e respeito aos direitos humanos (AFRICAN GROWTH AND OPPORTUNITY ACT [AGOA], [s.d.]).
} 
teria se concentrado nos países africanos, caribenhos e do Pacífico, o próprio Presidente Bush teria telefonado aos lideres da África do Sul, Brasil e Índia, com o objetivo de desestimulá-los a seguirem assumindo posições firmes e contrárias aos países desenvolvidos. Os EUA também estariam pressionando países árabes (BRIDGES, 2003c).

Segundo VanGasstek, "Mr. Zoellick's chief objective was to break this block [G20] apart" (VANGRASSTEK, 2013, p. 442). Entre outros, os EUA teriam prometido iniciar a negociação de acordos de livre comércio (Free Trade Agreements - FTAs) com os países que concordassem em deixar o G20 (VANGRASSTEK, 2013).

Narlikar e Tussie reportam outros mecanismos a que os EUA teriam recorrido com a finalidade de dissuadir países de se associarem, ou permanecerem associados, ao G20 e às demais coalizões de PEDs que se opunham à proposta EUA-UE:

For instance, the US is reported to have offered carrots in the form of tariff quotas to some of the Central American countries and sticks that included the threat of slowing down regional integration (NARLIKAR; TUSSIE, 2004, pp.960-961).

As mesmas autoras apontam que embora observadores previssem o colapso do G20, ele resistiu à pressão bilateral sobre os seus membros por parte do Quad (EUA, UE, Japão e Canadá), e se manteve coeso até o fim da Conferência de Cancun (NARLIKAR; TUSSIE, 2004). Com efeito, o facilitador George Yeo teria reconhecido: "There is a new power triangle at the WTO (...) - the United States, the European Union, and the G20" (BLUSTEIN, 2009, p. 147).

Na reunião Plenária, os EUA defenderam a proposta EUA-UE como uma tentativa de "energizar as negociações", e a UE, embora tenha admitido que os PDs deveriam fazer mais para abrir seus mercados que os PEDs, considerou a proposta do G20 "falha e desbalanceada", por onerar apenas os PDs, preservando PEDs que são fortes exportadores agrícolas ${ }^{58}$ (BRIDGES, 2003c).

Já em contato com o facilitador do Grupo de Trabalho em Agricultura, George Yeo, os negociadores do G20 insistiram na importância dos aspectos procedimentais durante a Conferência. Eles defenderam que houvesse negociação direta entre as delegações, em lugar de o Chair assumir a função de arbitrar entre posições fixas e concorrentes; e que o Chair produzisse um draft suficientemente cedo para permitir às delegações analisá-lo e emendá-lo, ao invés de receberem um fait accompli na reta final das negociações (BRIDGES, 2003c).

\footnotetext{
${ }^{58} \mathrm{O}$ mesmo argumento seria retomado pelo Representante para o Comércio dos EUA, como se verá.
} 


\subsubsection{Segundo dia - Quinta-feira, 11 de setembro de 2003}

$\mathrm{Na}$ reunião de Chefes de Delegação da manhã do segundo dia, os facilitadores informaram que haviam iniciado consultas com delegações individuais e pequenos grupos (WTO, 2003g).

O Grupo de Trabalho sobre os "Temas de Cingapura" reuniu-se no início da tarde. O facilitador, o canadense Pierre Petigrew, recordou as duas opções sobre o assunto incluídas no draft da Decisão Ministerial: ou seriam lançadas negociações sobre esses temas em Cancun, ou eles seriam remetidos a Genebra, para esclarecimento. $\mathrm{O}$ facilitador recordou ainda que além das opções incluídas no draft, havia diversas alternativas intermediárias (WTO, 2003g).

Distintos PEDs, incluindo Bangladesh, China, Índia, Malásia e Nigéria (BRIDGES, 2003d), afirmaram ser evidente não haver consenso para iniciar negociações nos quatro temas, tal como exigido pela Declaração de Doha; a matéria deveria, portanto, ser remetida de volta a Genebra. Esse grupo de países pediu, ainda, que não se condicionasse a evolução de outras discussões em Cancun ao avanço nesses temas; ao contrário, todos deveriam se concentrar em temas em que fosse possível alcançar resultados (WTO, 2003g). Nesse sentido, falando em nome do grupo - que contava com mais de 70 países - e referindo-se, principalmente, aos possíveis avanços em Agricultura, a Ministra do Comércio da Malásia, Rafidah Aziz, afirmou: "Each issue should be considered in its own merits" (BRIDGES, 2003d, p.2).

É importante notar que embora esse grupo tenha afirmado não estar pronto, naquele momento, para lançar as negociações nos “Temas de Cingapura”, os países não chegaram a se opor abertamente a negociações futuras. Eles apenas demandavam mais tempo para esclarecer as consequências da negociação desses novos temas e para melhorar a capacitação dos países em desenvolvimento (BRIDGES, 2003d).

Em contraste, outro grupo, formado por PDs e PEDs, sustentou que os "Temas de Cingapura" integravam a Declaração de Doha da mesma forma que Agricultura e NAMA, e, por isso, deixar de lançar negociações nessas áreas em Cancun representaria um retrocesso. Defendeu ainda que sete anos de discussões (desde a Primeira Conferência Ministerial) haviam esclarecido a matéria; que a demora em fazer avançar as negociações retardaria potencial expansão do crescimento de PEDs e que essas novas regras eram demandadas pelas empresas, sendo necessário que a OMC lidasse com a realidade da era moderna (WTO, 2003g). 
A UE, principal demandante nesta matéria, delineou três objetivos para os "Temas de Cingapura" em Cancun: que as negociações fossem lançadas, com vistas a serem concluídas até janeiro de 2005; que se acordasse o escopo das negociações; e que todos os países fossem incluídos no acordo (BRIDGES, 2003d).

Alguns países latino-americanos, como Colômbia, Peru e Chile afirmaram que apoiariam o estabelecimento de modalidades ${ }^{59}$ nos "Temas de Cingapura" desde que houvesse movimento em outras áreas, particularmente Agricultura (BRIDGES, 2003d). Finalmente, um grupo reduzido de PEDs apoiou o lançamento de negociações em apenas dois dos quatro "Temas de Cingapura" - facilitação de comércio e transparência em compras governamentais -, que estariam mais maduros que os outros dois temas (WTO, 2003g).

Perguntado sobre possíveis caminhos para aproximar posições tão divergentes, o facilitador Pettigrew mencionou algumas possibilidades: negociar em Cancun apenas alguns dos "Temas de Cingapura", ficando os demais para um momento posterior; negociar os "Temas de Cingapura", ressalvando expressamente que solução de controvérsias não seria incluída nas modalidades; negociar trade-offs com outras áreas negociadas em Cancun; ou seguir um modelo de acordo plurilateral (ou seja, de adesão voluntária) (BRIDGES, 2003d).

O Grupo de Trabalho de Agricultura reuniu-se na noite do segundo dia. Na reunião, o facilitador George Yeo, de Cingapura, relatou ter realizado três encontros ao longo do dia: com o G20 e a UE, com os EUA e a UE, e com o G20 e os EUA (WTO, 2003g).

Segundo Paul Blustein, o Representante para o Comércio dos Estados Unidos, Robert Zoellick, incialmente havia se recusado a se encontrar com os líderes do G20, convencido que estava da pequena longevidade do grupo, mas acabou cedendo aos apelos do facilitador Yeo. Blustein assim descreve o encontro entre esses negociadores:

On the ministerial's second full day, a glowering Zoellick entered an amphitheater in the Cancún convention center that was packed with G-20 officials from Latin America, Asia, and Africa. (...)

Zoellick sat down, a bottle of water on the desk in front of him, and opened the meeting, as he often does, with this question: 'What's on your mind?'

The leaders of the G-20 - Celso Amorim, the Brazilian foreign minister, and Arun Jaitley, the Indian commerce minister, in the main speaking roles - presented the conditions that, they said, were required for a successful Doha Round. (...)

Zoellick (...) waited until they had stopped speaking. Then he invited them to continue.

\footnotetext{
${ }^{59} \mathrm{Um}$ acordo em modalidades, nas negociações da OMC, implica em definir uma maneira específica de proceder, ou um modus operandi, estabelecendo-se linhas gerais, como fórmulas ou abordagens para reduções tarifárias, para se chegar ao compromisso final (WTO, 2005a)
} 
We're finished, Amorim said. But Zoellick, with exaggerated courtesy bordering on sarcasm, urged them again to keep talking. An awkward silence ensued.

You've just given me a long list of the things that you want, Zoellick said. But this is a negotiation. You haven't said what you're going to give. Are you going to provide that half of your presentation?

Again there was silence, and Zoellick said he guesses the discussion was over. He rose and left. (BLUSTEIN, 2009, p. 148)

Segundo Blustein, ao recordar o episódio, participantes do G20 admitem que eles não estavam preparados para o desafio lançado por Zoellick.

Após os três encontros, apesar de ter percebido algumas indicações de flexibilidade, o facilitador Yeo afirmou que as delegações "were still mainly keeping their cards close to their chests." (WTO, 2003g, p.1) Ele afirmou ainda que, caso as diferenças entre as posições não se reduzissem, ele mesmo prepararia um texto que seria apresentado no final do dia seguinte (ou seja, o terceiro dia de reuniões). O texto seria um "híbrido", com elementos do draft circulado em Genebra e outras propostas (WTO, 2003g).

No tema do Algodão, o facilitador e Diretor-Geral da OMC, Supachai Panitchpakdi, convocou uma reunião com a participação dos proponentes da iniciativa e dos países identificados como fornecedores de subsídios (WTO, 2003h). Embora todos tenham concordado com a necessidade de se encontrar uma solução para a questão (WTO 2003h), os EUA seguiram recusando-se a discutir a redução de seus subsídios, e insistiram em uma solução que abrangesse, de forma ampla, o setor de fibras e têxteis; já os países africanos continuaram demandando uma solução focada nos problemas imediatos dos pequenos agricultores de algodão (BRIDGES, 2003d).

Nas discussões sobre NAMA houve algum progresso, mas permaneceram divergências relacionadas à fórmula para redução tarifária e às inciativas setoriais. O facilitador Henry Tang Ying-yen (ministro das Finanças de Hong Kong) sugeriu que o assunto deveria ser considerado

por seus próprios méritos, mas diversos países ressaltaram que o tema estava vinculado às negociações em Agricultura (WTO, 2003h).

\subsubsection{Terceiro dia-Sexta-feira, 12 de setembro de 2003}

Na reunião de Chefes de Delegação da manhã do terceiro dia da Conferência (que chegava, portanto, à sua metade), o Chair Derbez ressaltou que, embora sinais de progresso estivessem surgindo, em diversas questões o distanciamento entre as delegações permanecia. Ele 
instou os Ministros a buscarem soluções conciliadoras: "Ministers need to work together urgently to find solutions that all governments can live with. No text could ever fully satisfy all the objectives of all WTO Members - this is the nature of compromise", declarou Derbez (WTO, 2003h, p.1).

Na reunião do Grupo de Trabalho (GT) sobre os "Temas de Cingapura", coordenada pelo canadense Petigrew, os posicionamentos tradicionais foram mantidos - o que levou um participante a denominar as discussões em Cancun de "Geneva by the sea" (BRIDGES, 2003e, p.2). O grupo de mais de 70 países em desenvolvimento liderado pela Índia continuou defendendo que não havia o consenso explícito exigido na Declaração de Doha para o lançamento de negociações. A UE, por sua vez, insistiu que as negociações já haviam sido lançadas na Declaração de Doha, o que levou um porta-voz do Representante para o Comércio dos EUA a afirmar que, nos "Temas de Cingapura", a UE havia "isolated themselves from the world" (BRIDGES, 2003e, p.2).

Ainda no GT de "Temas de Cingapura", diversos países, PDs e PEDs, incluindo os EUA, mais uma vez apoiaram o lançamento de negociações em facilitação de comércio e transparência em compras governamentais, e foram bem recebidos pelo facilitador Petigrew. Finalmente, alguns PEDs, como Paquistão e África do Sul, afirmaram que o avanço nesta área vinculava-se ao progresso em Agricultura (WTO, 2003h; BRIDGES, 2003e).

Também no GT de Agricultura as posições originais foram substancialmente mantidas, embora o facilitador George Yeo tenha declarado perceber certa flexibilidade em suas consultas informais. A principal novidade foi um texto apresentado pelos países da África, Caribe e Pacífico (ACP, na sigla em inglês) e por PMDRs, demandando framework e modalidades "equilibrados" entre os três pilares, e incluindo tratamento especial e diferenciado aos PEDs. Alguns membros do G20 deram as boas vindas à proposta, e identificaram-na com aquela apresentada pelo Grupo (WTO, 2003h).

Quanto ao Algodão, segundo relatado pelo facilitador para o tema e Diretor-Geral Supachai, os Membros tenderam a convergir em torno de dois pontos: em primeiro lugar, que as soluções buscadas deveriam se ater aos aspectos comerciais levantados pelo Cotton 4, claramente sob o âmbito da OMC, deixando-se para outro momento e lugar a discussão dos aspectos financeiros da inciativa, já que necessariamente deveriam envolver outras instituições internacionais com atuação na área de assistência. Além disso, ter-se-ia convergido para uma 
vinculação (linkage) entre as discussões sobre o tema do Algodão e Agricultura (WTO, 2003h; BRIDGES, 2003e).

Naquela noite, houve uma segunda reunião de Chefes de Delegação, em que os facilitadores informaram os avanços do dia e comentaram a preparação dos drafts em seus respectivos temas. O facilitador de Agricultura relatou ter havido bom progresso, com todos os Membros esforçando-se para superar as diferenças, o que tornava mais fácil a sua tarefa de redigir um texto. Em contraste, o facilitador do GT dos "Temas de Cingapura" ressaltou estar claro que as posições seguiam polarizadas, e que era difícil visualizar um caminho a seguir; de todo modo, ele prepararia um texto e entregaria ao Chair Derbez "nas próximas horas". O facilitador de NAMA, a seu turno, relatou ter sondado, com diferentes grupos, possíveis drafts, afirmou esperar poder apresentar versões melhoradas "muito em breve" e solicitou que os Ministros fossem flexíveis (WTO, 2003h).

O Chair Derbez recordou aos Ministros que faltavam apenas 42 horas até a seção de encerramento da Conferência. Ele informou que, a partir das contribuições dos facilitadores, iria elaborar um novo draft de Declaração Ministerial, que seria circulado entre os Membros, nos três idiomas oficiais da OMC, até o horário do almoço do dia seguinte. A partir daquele momento, o trabalho dos facilitadores seria unificado em um processo único; o Chair e o DG Supachai iriam seguir promovendo reuniões e consultas, com vistas a se alcançar um resultado satisfatório para todos (WTO, 2003h).

\subsubsection{Quarto dia - Sábado, 13 de setembro de 2003}

Como prometido, o novo draft de Declaração Ministerial foi distribuído ao meio-dia do quarto dia da Conferência, em uma reunião de Chefes de Delegação convocada especialmente para esse fim. O Chair Derbez ressalvou que se tratava, ainda, de um rascunho, em que se buscou reunir os insights obtidos por meio das diversas formas de consulta, com vistas a construir um pacote amplo que fosse passível de aceitação geral (WTO, 2003i). A reunião foi interrompida por volta das $13 \mathrm{~h}$, e recomeçou às $19 \mathrm{~h}$.

Manifestando suas impressões iniciais sobre o texto, diversos Ministros fizeram uso da palavra. Embora muitos tenham reconhecido o esforço de superação das divergências empregado 
na elaboração do texto, a maior parte criticou aspectos com os quais não concordava, argumentando que o draft não refletia as suas posições (WTO, 2003i).

A insatisfação foi evidente em relação ao tratamento conferido à Agricultura. $\mathrm{Na}$ realidade, "Every single Member disagreed with major aspects of the agriculture draft" (BRIDGES, 2003f). Alguns Membros, como Noruega, Japão, Coreia e Suíça (por meio do $\mathrm{G} 10^{60}$ ), criticaram o texto por ser ambicioso demais. Já o G20 considerou que o draft não foi longe o bastante, entre outras razões, por não enunciar com clareza a eliminação total dos subsídios à exportação (BRIDGES, 2003f).

Quanto aos "Temas de Cingapura", também houve grande descontentamento e grande divergência. O draft proposto pelo Chair alterava substancialmente a versão distribuída antes da Conferência: ele previa o lançamento imediato das negociações de dois dos quatro temas facilitação de comércio e transparência em compras governamentais - e, após esclarecimentos ${ }^{61}$, de um terceiro - investimentos (apenas as negociações em concorrência não seriam lançadas). A UE manifestou insatisfação com o texto, e defendeu o lançamento imediato das negociações em investimentos. Já a Índia notou a ausência de menção ao consenso explícito para o lançamento de negociações em investimentos e concorrência. A Malásia afirmou que não poderia apoiar nenhum texto que implicasse no início de negociações desses temas, e que essa posição não era negociável, independentemente de avanços em qualquer outra área. Algumas ONGs classificaram o texto de "escandaloso" (BRIDGES, 2003f).

Quanto a NAMA, não houve grandes mudanças em relação ao draft anterior, que havia gerado manifestação de descontentamento por parte de diversos PEDs. Manteve-se, por exemplo, linguagem prevendo uma fórmula não-linear para redução tarifária, a despeito da posição da Índia e outros PEDs, que defendiam uma fórmula linear (BRIDGES, 2003f).

O tratamento dado ao tema do Algodão também despertou críticas contundentes por parte dos PEDs, e particularmente dos países do Cotton 4, já que o texto não refletia nem a demanda de eliminação dos subsídios ao algodão, nem a do pagamento de compensação pelos impactos negativos causados às exportações desses países africanos. O grupo de países da ACP destacou que a iniciativa do algodão havia recebido apoio esmagador entre os Membros, e que esperava que o texto final desse uma resposta às suas preocupações. O Mali defendeu que a proposta do

\footnotetext{
${ }^{60}$ Grupo formado por Bulgária, Islândia, Israel, Japão, Coreia, Liechtenstein, Ilhas Maurício, Noruega, Suíça e Formosa.

${ }^{61}$ Os esclarecimentos ocorreriam em Sessões Especiais do Grupo de Trabalho sobre Investimentos, da OMC.
} 
Cotton 4 fosse adotada tal como havia sido apresentada, e foi apoiado por diversos outros países. Um representante da indústria africana do algodão declarou: "We are used to hardship, disease and famine. Now the WTO is against us as well. I think this will stay in history" (BRIDGES, 2003f, p.1). Mesmo Pascal Lamy, Comissário Europeu para o Comércio, descreveu o texto do algodão como excessivamente vago, e exigiu que o tema fosse tratado nos três pilares das negociações em Agricultura (BRIDGES, 2003f).

No encerramento da reunião de Chefes de Delegação na noite do sábado, o Chair Derbez afirmou que iria refletir sobre os comentários dos Ministros. Tendo em vista o prazo exíguo até o final da reunião, de menos de 24 horas, ele manifestou preocupação com a disposição dos Membros para trabalhar em conjunto e alcançar o consenso. Para o Chair, era compreensível que os Ministros quisessem deixar registradas as suas posições, mas ele se preocuparia caso eles estivessem dispostos a deixar que o processo fracasse. Ele alertou que, se Cancun falhasse, as negociações poderiam levar um longo tempo para se recuperar (WTO, 2003i).

A reunião foi suspensa à $1 \mathrm{~h}$ da manhã do domingo, para que as delegações seguissem com sua análise ao texto e para que o Chair Derbez, o DG Supachai e os facilitadores fizessem as consultas necessárias. Caso houvesse progresso, o Chair reconvocaria a reunião de Chefes de Delegação no domingo, 14 de setembro, último dia da reunião.

\subsubsection{Quinto dia - Domingo, 14 de setembro de 2003}

O Chair Derbez iniciou as consultas imediatamente após o encerramento da reunião de Chefes de Delegação, na madrugada do dia 13 para o dia 14 de setembro. A primeira consulta, com um grupo restrito de Membros, focou nos "Temas de Cingapura", e estendeu-se até as 4h da manhã (WTO, 2003j).

Diante da dificuldade revelada nas discussões, o Chair Derbez decidiu que a consulta seguinte, que teria início cerca de 8h30 da manhã do domingo, seria mais uma vez entrada nos “Temas de Cingapura” (WTO, 2003j). Alguns observadores questionaram essa decisão do Chair, já que diversos países em desenvolvimento haviam insistido, nos dias anteriores, que eventual progresso nos "Temas de Cingapura" dependeria de avanços em Agricultura (BRIDGES, 2003g). De fato, não era de se esperar que esses países demonstrassem flexibilidade nestes temas, sem antes saber se as discussões em Agricultura iriam caminhar a seu favor (VANGRASSTEK, 2013) 
Desta reunião participou um grupo ainda restrito de Membros, e muitas delegações representavam grupos mais amplos (BRIDGES, 2003g). Durante a manhã, discutiram-se diversas opções para os “Temas de Cingapura", principalmente a possibilidade de separá-los e identificar, dos quatro temas, quais estariam suficientemente maduros para serem negociados. Com o andamento das discussões, verificou-se que a UE (como se sabe, principal demandante no assunto) aceitaria, em Cancun, lançar apenas as negociações de facilitação de comércio e transparência em compras governamentais:

As the day wore on, it emerged that the $\mathrm{EC}^{62}$ was prepared to take investment and competition out of the Doha Round and the WTO, leaving trade facilitation and transparency in government procurement for launch at Cancun (BRIDGES, 2003g)

No início da tarde, a reunião foi suspensa por uma hora para permitir às delegações presentes reportarem-se aos seus grupos, de forma a dar maior transparência ao processo. $\mathrm{O}$ Chair Derbez enfatizou que o fracasso em obter consenso nos "Temas de Cingapura" o levaria a encerrar a reunião, já que o dissenso poderia levar a um acirramento ainda maior das posições defensivas em Agricultura (VANGRASSTEK, 2013). De acordo com o periódico Bridges, participantes da reunião relataram que, nesse momento, o ambiente entre as delegações era bom ("the mood before the recess was 'good"”) (BRIDGES, 2003g, p.1).

Durante o intervalo, a UE teria consultado o Conselho de Ministros da Comissão Europeia, que teria concordado, em princípio, com a ideia de separar os "Temas de Cingapura", embora esperassem também por avanços em outras áreas (BRIDGES, 2003g). Tratava-se, como notou VanGasstek, de uma "grande concessão" da parte da UE: o bloco concordaria em abandonar não apenas dois, mas três dos quatro "Temas de Cingapura", desde que se acordasse com o início imediato das negociações no tema menos controverso, facilitação de comércio (VANGRASSETK, 2013).

Embora notável, segundo VanGrasstek a concessão europeia veio muito tarde, e muitos dos PEDs que se opunham fortemente aos "Temas de Cingapura" sequer tomaram conhecimento, naqueles momentos finais das negociações, do movimento da UE. Outros já haviam assumido posições excessivamente defensivas e viam-se impedidos, àquela altura, de recuar:

Several of the participants in these negotiations would later observe that the concession might have helped if it were made earlier, but that when it did come the opposition was too entrenched to be persuaded (VANGRASSETK, 2013, p. 444).

De fato, quando os participantes retornaram do intervalo, as posições haviam endurecido. Botswana, falando em nome da União Africana, afirmou ser incapaz de aceitar qualquer acordo

${ }^{62}$ European Comission (Comissão Europeia) 
que incluísse qualquer um dos "Temas de Cingapura". Em seguida, a Coreia do Sul, apoiada pelo Japão, afirmou não poder aceitar um acordo que não incluísse os quatro temas. A UE e a China, por sua vez, comentaram que, ao seu ver, ainda havia espaço para aprofundar a discussão na matéria (BRIDGES, 2003g).

Diante das manifestações das delegações, e a despeito das falas da UE e da China, o Chair Derbez afirmou que não acreditava ser possível reconciliar as posições nos "Temas de Cingapura", já que os negociadores haviam-se mostrado inflexíveis (BRIDGES, 2003g). Era chegado o momento, para o Chair, de concluir aquele processo. Ele decidiu, então, encerrar a Conferência Ministerial (WTO, 2003j).

Alguns países objetaram à decisão, insistindo que se fizesse um esforço concentrado de negociação em Agricultura antes do encerramento. Derbez inicialmente consentiu e solicitou aos Ministros iniciarem as discussões, mas Membros do G10 indicaram que, com a rejeição dos quatro "Temas de Cingapura", eles seriam ainda mais insistentes em suas posições defensivas em Agricultura. Sendo assim, o Chair Derbez decidiu encerrar definitivamente a Conferência Ministerial de Cancun (VANGRASSETK, 2013).

A decisão do Chair surpreendeu e desagradou um grande número de Membros. Patricia Hewitt, Secretária para o Comércio e a Indústria do Reino Unido, declarou, pouco após o anuncio do encerramento da Conferência, que a decisão de Derbez havia sido "totalmente inesperada" e "prematura". Indicando disposição da UE para seguir negociando, ela afirmou: "There was a deal to be had" (BRIDGES, 2003g, p.1).

A partir da decisão de encerrar a Conferência, o Chair Derbez convocou uma reunião de Chefes de Delegação, com início às 16h. Ele propôs um statement ministerial, composto por seis parágrafos, que foi aprovado às $18 \mathrm{~h}$, na seção de encerramento da Conferência. Ao mesmo tempo em que reconheceu o retrocesso em Cancun, o statement reiterou os compromissos de Doha e previu a continuidade das discussões (WTO, 2003j).

Um conjunto amplo e diversificado de fatores foi apontado como causa do fracasso em Cancun, o que levou VanGrasstek (2013, p. 445) a observar:

Whoever coined the saying that victory has a thousand fathers but defeat is an orphan never had to sort out the aftermath of the Cancún Ministerial Conference. No one came forward to take the blame personally, but a great many fingers pointed at others to whom the paternity might be ascribed. 
Assim, a falta de consenso quanto ao lançamento de negociações formais sobre os "Temas de Cingapura" foi apontado por muitos como causa imediata do colapso da reunião (EVENETT, 2003; CHO, 2004).

Ao mesmo tempo, foi ressaltado também o papel importante do dissenso no tema da Agricultura. Sublinhando a relevância deste tema para o colapso em Cancun, Narlikar e Tussie ressaltam:

Irrespective of the final machinations on the last day when the lack of agreement on the Singapore issues was presented as the ostensible reason for the end of the meeting, agriculture had in fact been the bête noir through most of the conference as well as in the run-up to it (NARLIKAR; TUSSIE, 2004, p. 953, grifos da autora) ${ }^{63}$.

Ao final da reunião, o Representante para o Comércio Exterior dos EUA responsabilizou Brasil, Índia e China pelo fracasso em Cancun (CARVALHO, 2010). Em artigo publicado em 22 de setembro de 2003 no periódico Financial Times, Zoellick (2003) fez um balanço dos cinco dias de negociações. Ele criticou o que considerou a transformação da OMC em um fórum para "políticas de protesto", e sustentou que houve em Cancun uma clara divisão entre os países can$d o$ (dispostos a fazer) e won't do (o oposto). Finalmente, ele afirmou que os EUA não iriam esperar os Membros da OMC "ponderarem sobre o futuro"; em lugar disso, iriam se engajar em negociações de livre comércio com aqueles países que estivessem dispostos a fazê-lo (can-do countries).

De outra parte, houve quem atribuísse o fracasso da reunião aos EUA, por terem-se mostrado inflexíveis às demandas dos PEDs, notadamente à iniciativa do Cotton 4; e também à UE, por terem demonstrado tarde demais alguma flexibilidade nos "Temas de Cingapura" (VANGRASSTEK, 2013). Organizações da sociedade civil como ActionAid, Oxfam e Greenpeace adotaram essa linha (BRIDGES, 2003g).

Houve, por outro lado, quem responsabilizasse a presidência "pouco inspirada" por parte do chanceler mexicano Derbez (EVENETT, 2003; CHO, 2004) e ao encerramento prematuro da reunião. O comportamento do Chair Derbez chegou a ser associado a um alegado interesse norteamericano de que a reunião fosse malsucedida (NARLIKAR; WILKINSON, 2004).

Entre as causas imediatas do fracasso em Cancun foram apontadas ainda o declínio da hegemonia norte-americana; a crise do capitalismo; a utilização de estratégias de negociação

\footnotetext{
${ }^{63} \square$ Em uma construção contrafactual, as autoras sustentam que mesmo que o dissenso em torno dos "Temas de Cingapura" tivesse sido superado no último dia da Conferência (o que poderia ter ocorrido, tendo em vista a disposição manifestada pela UE para recuar e abandonar dois ou três dos quatro "Temas" ), a insatisfação do G20 com os drafts sobre Agricultura tornava improvável o consenso (NARLIKAR; TUSSIE, 2004).
} 
contraproducentes por parte dos PEDs e a atuação de ONGs que incitaram os países a adotarem essas estratégias (NARLIKAR; WILKINSON, 2004). É de se notar que organizações da sociedade civil como a International Gender and Trade Network e a Africa Trade Network comemoraram o colapso da Conferência como um símbolo das transformações na distribuição do poder na OMC: "a major political shift in the power dynamics of the WTO with developing countries successfully resisting power in the face of extreme pressure and bullying" (BRIDGES, 2003 g, p.2).

Apontou-se, ainda, a dificuldade de vários Membros da OMC (particularmente PEDs) em negociar ou discutir vários temas simultaneamente, durante e antes da Conferência; e uma percepção de que alguns delegados não estavam preparados para ir além de demandas prédeterminadas, demonstrando pouca propensão a negociar com seriedade (EVENETT, 2003).

Características procedimentais também foram apontadas como responsáveis pelo colapso. Pascal Lamy reiterou comentário feito à época da Conferência de Seattle, e sustentou, ao final da reunião de Cancun, que a OMC continuava sendo uma "instituição medieval": "there is no way to structure and steer discussions amongst 146 members in a manner conducive to consensus", afirmou (LAMY, 2003b). Finalmente, para Amrita Narlikar e Rorden Wilkinson (2004), falhas no desenho institucional e no funcionamento da OMC (como a ausência de regras procedimentais claras), associadas ao desequilíbrio substantivo em seus acordos, teriam levado ao resultado negativo em Cancun.

\subsection{Entre Cancún e Hong Kong: o Pacote de Julho de 2004}

Após o fracasso em Cancun, as tratativas foram retomadas em uma reunião do Conselho Geral da OMC realizada em Genebra, em julho de 2004. A intenção era recolocar as negociações em movimento antes da realização da Sexta Conferência Ministerial; assim, mais do que avançar concretamente nos compromissos de Doha, buscava-se alcançar alguma forma de acordo, independentemente da matéria (STRICKNER; SMALLER, 2004).

Nesse sentido, a reunião foi vitoriosa: o chamado "Pacote de Julho", adotado nas primeiras horas do dia $1^{\circ}$ de agosto de 2004, ofereceu um framework com base no qual as negociações poderiam prosseguir. Ele continha anexos específicos com recomendações para as negociações de Serviços e modalidades em Agricultura, NAMA e Facilitação de Comércio, 
confirmando a exclusão da Rodada dos outros três "Temas de Cingapura" (VANGRASSTEK, 2013).

Ao final da reunião, Robert Zoellick, ainda Representante para o Comércio dos EUA, declarou: "After the detour in Cancún, we have put these WTO negotiations back on track" (ZOELLICK, 2004, p.1). E Pascal Lamy, também atuando, ainda, como Comissário Europeu para o Comércio, complementou: "I said in Cancún that the WTO was in intensive care. Today I can say that it is not only out of the hospital but well and running" (LAMY, 2004, p.1)

É importante notar que os principais acordos do "Pacote de Julho" foram gestados não pelo chamado Quad (EUA, UE, Japão e Canadá), como era típico nas negociações comerciais multilaterais até então, mas por um novo grupo de países, denominado "Cinco Partes Interessadas" (FIPs, na sigla em inglês), composto por EUA, UE, Brasil, Índia e Austrália. Mantinha-se a tradição do GATT-OMC de negociação a partir de "círculos concêntricos" - em que um pequeno grupo de países primeiro alcança acordo entre eles, sendo tais acordos sucessivamente submetidos à consideração de grupos cada vez mais amplos, e, em última instância, à totalidade dos Membros da OMC, que devem aprovar todas as decisões por consenso (BLUSTEIN, 2009) - mas, agora, com novos atores.

Após a aprovação do "Pacote de Julho", assumiu-se que não seria possível cumprir o prazo de $1^{\circ}$ de janeiro de 2005 para a conclusão da Rodada, conforme originalmente previsto na Declaração de Doha. Informalmente, os Membros da OMC passaram a trabalhar com o objetivo principal de acordarem as modalidades para as negociações em Agricultura e NAMA na Conferência de Hong Kong, e concluírem a Rodada até o final de 2006. Não por coincidência, em meados de 2007 expirava a Trade Promotion Authority concedida pelo Congresso dos EUA ao Presidente Bush, que garantia a deliberação sobre os resultados da Rodada Doha pelo legislativo norte-americano sem a possibilidade de emendas por parte dos parlamentares, sendo possível apenas a aprovação ou rejeição total do acordo (BRIDGES, 2005a).

\subsection{Conferência de Hong Kong}

O resultado positivo de julho de 2004 elevou temporariamente as expectativas em relação aos avanços possíveis em Hong Kong. Esperava-se que na Sexta Conferência Ministerial o framework pudesse se transformar em compromissos concretos, o que possibilitaria a conclusão 
das negociações da Rodada Doha com apenas um ano de atraso em relação à previsão original ou seja, 2006, e não 2005 (VANGRASSTEK, 2013).

A esse respeito, Paul Blustein esclarece:

Even though the framework agreement had been approved in 2004, real numbers were still needed to give concrete meaning to the framework's broad principles concerning the ways tariffs and subsidies would be cut and the exceptions that would be allowed. (BLUSTEIN, 2009, p. 204).

Lee e Wilkinson ressaltam o espírito construtivo que movia os negociadores nos meses que antecederam a Sexta Conferência Ministerial:

The run-up to the Hong Kong Ministerial was, nevertheless, qualitatively different from that which have preceded Seattle and Cancun. A willingness to keep moving forward with negotiations despite the persistence of significant differences was in evidence (LEE; WILKINSON, 2007, p. 7 - grifo da autora).

Em $1^{\circ}$ de setembro de 2005, o francês Pascal Lamy, ex-Comissário para o Comércio da UE, assumiu a função de Diretor-Geral da OMC, em substituição ao tailandês Supachai Panitchpakdi. Em seu discurso inicial, Lamy recordou o caráter member-driven da organização, e ressaltou o papel do Diretor-Geral: "We can catalyse, we can broker, sometimes, sometimes we can lead, but at the end of the day, they [os Membros da OMC] take the decision" (BRIDGES, 2005b, p.1)

Discursando duas semanas depois, em 14 de setembro de 2005, Lamy afirmou que mesmo não significando o final da Rodada Doha, a Conferência de Hong Kong deveria garantir terem sido percorridos "dois terços" do caminho. Para Lamy, àquela altura ainda havia grandes ambições de que resultados significativos poderiam ser alcançados até dezembro, em um conjunto amplo de questões; para tanto, era necessário trabalhar em Genebra de forma focada e séria, com disposição de aceitar as necessidades dos demais Membros e "energia criativa" para encontrar soluções que todos pudessem aceitar (LAMY, 2005a).

Mais uma vez, a Agricultura era apontada como tema central na preparação para a Conferência. Em 10 de outubro, os EUA haviam apresentado uma proposta na matéria, que previa a redução substancial nos limites permitidos para seus próprios subsídios agrícolas, mas, ao mesmo tempo, exigia redução ainda maior nos subsídios permitidos à UE e ao Japão. Além disso, previa, tanto para PDs como para PEDs, reduções tarifárias em produtos agrícolas e NAMA, além de abertura em Serviços (BLUSTEIN, 2009, p. 205).

Alguns dias depois, a UE apresentou a sua proposta, que continha oferta de acesso a mercados em Agricultura significativamente inferior ao que se esperava. EUA, Austrália, G20 e o 
Grupo de Cairns ${ }^{64}$ acusaram os europeus de comprometerem o avanço das negociações, e alertaram que outras áreas das negociações, como NAMA e Serviços, permaneceriam bloqueadas até a melhora da oferta de acesso a mercados em Agricultura da UE. Por sua vez, o Comissário Europeu para o Comércio, Peter Mandelson (sucessor de Pascal Lamy), afirmou que apenas após avanço nas negociações em NAMA e em Serviços ele poderia ofertar concessões adicionais em Agricultura (BRIDGES, 2005c).

Mandelson estava limitado por pressões internas, notadamente da França:

In internal consultations in late October, France warned the EU negotiating team that it should not overstep its mandate, which in its view was strictly tied to existing agricultural subsidy spending and the 2003 reform of the EU's Common Agricultural Policy, by making concessions in the negotiations that would not be acceptable to EU member sates (US Government Acountability Office [GAO], 2006, p. 15).

Sob forte pressão dos demais Membros, no final de outubro a UE apresentou uma nova oferta de acesso a mercados em Agricultura, condicionada a concessões específicas e ambiciosas em virtualmente todas as áreas negociadas na Rodada Doha. Além de exigir cortes substanciais nas tarifas industriais dos PEDs, a UE demandava desses mesmos países metas obrigatórias, tanto qualitativas quanto quantitativas, para a liberalização do setor de Serviços. A UE buscava, ainda, a extensão a todos os produtos da proteção adicional conferida pelo Acordo TRIPS apenas às indicações geográficas de vinhos e destilados; e diferenciava diversas classes de PEDs não considerados como PMDRs - um tema nunca acordado na OMC e tabu para muitos dos seus Membros (BRIDGES, 2005d).

Quanto às preocupações com o Desenvolvimento, a UE propôs aos PDs acordar, na Conferência de Hong Kong, a concessão de acesso total, sem tarifas e sem cotas (“duty free, quota free"), às exportações dos PMDRs. Finalmente, quanto ao Algodão, propôs aos PDs o compromisso de superar os efeitos distorcivos das suas políticas, com a previsão de datas e modalidades para a implementação antecipada (BRIDGES, 2005d).

Após a apresentação da nova proposta europeia, e reagindo à afirmação de Mandelson de que a UE havia feito tudo o que razoavelmente se podia esperar que o bloco fizesse em Agricultura, enquanto outros Membros não teriam retribuído em NAMA e em Serviços, o chanceler brasileiro Celso Amorim afirmou que as condicionalidades demandadas pela UE eram

\footnotetext{
${ }^{64}$ O Grupo de Cairns foi formado em 27 de agosto de 1986, às vésperas do lançamento da Rodada Uruguai da OMC, visando defender a liberalização comercial na Agricultura. Atualmente, é formado por África do Sul, Argentina, Austrália, Brasil, Canadá, Chile, Colômbia, Costa Rica, Filipinas, Guatemala, Indonésia, Malásia, Nova Zelândia, Paquistão, Paraguai, Peru, Tailândia, Uruguai e Vietnã (THE CAIRNS GROUP, [s.d.]).
} 
tão desproporcionais ao nível de acesso ofertado para bens agrícolas que pareciam ter sido concebidas, essencialmente, para dificultar o progresso em Agricultura (BRIDGES, 2005d).

Não foi apenas o Brasil que reagiu negativamente à proposta da UE. Os EUA se declararam "desencorajados"; para eles, a proposta não atendia ao critério de melhoria substancial de acesso a mercados em Agricultura. Igualmente a Austrália afirmou estar “desapontada" (BLUSTEIN, 2009, p. 209).

Em novembro as diferenças na matéria levaram as delegações em Genebra a manifestarem para o Chair do grupo de negociações em Agricultura, o neozelandês Crawford Falconer, que não esperavam dele a elaboração de um "texto de compromisso"; ao contrário, as delegações pretendiam elaborar elementos de um draft e submetê-los ao Chair, que ficaria responsável por compilá-los e incorporá-los a um eventual futuro draft (BRIDGES, 2005e).

$\mathrm{Na}$ mesma época Lamy reconheceu que não havia convergência suficiente entre os Membros quanto ao nível de ambição em áreas chaves das negociações, o que impedia os Chairs dos grupos em Genebra de prepararem drafts com "modalidades completas" (“full modalities") para todos os elementos do "Pacote de Julho" (BRIDGES, 2005e). "We've made no progress at all on the main issues. What is on the table is not a basis for any agreement", afirmou Celso Amorim em uma reunião em Genebra, em 9 de novembro (BLUSTEIN, 2009, p. 211).

Em outras palavras, não seria possível, até dezembro, definir detalhadamente os valores e fórmulas para cortes tarifários de bens agrícolas e industriais. Esse trabalho teria que ficar para 2006 (BRIDGES, 2005f).

Era necessário, portanto, ajustar as expectativas para a Conferência de Hong Kong, abandonando o objetivo de alcançar o consenso em relação às "modalidades completas". Ainda que fosse desejo do novo DG que a primeira Conferência Ministerial sob a sua orientação representasse um passo importante para a conclusão da Rodada, para Lamy "keeping that objective, and not getting there, [was] too risky for the organization" (BLUSTEIN, 2009, p. 211).

Assim, em lugar da definição ampla das modalidades, passou-se a esperar, como resultado de Hong Kong, a consolidação dos ganhos obtidos desde o Pacote de Julho, bem como a determinação do que seria necessário para que as modalidades fossem acordadas no futuro próximo (BLUSTEIN, 2009).

Ao anunciar a redução das expectativas para Hong Kong, tanto o DG como Membros das FIPs ressalvaram que isso não implicava na redução do nível de ambição para a Rodada Doha 
como um todo (BRIDGES, 2005e; BLUSTEIN, 2009). Assim, Robert Portman, Representante para o Comércio dos EUA (sucessor de Rober Zoellick), afirmou, referindo-se ao caráter ambicioso da Rodada: "We have not given up; we will not give up" (BLUSTEIN, 2009, p. 211)

A dificuldade em avançar em Agricultura e em temas como NAMA e Serviços e o consequente ajuste nas expectativas para Hong Kong fizeram com que as discussões passassem a focar em outras questões, principalmente aquelas relacionadas ao Desenvolvimento. Assim, ainda em meados de novembro a UE anunciou que iria buscar, na Conferência, a "colheita antecipada" em uma série de temas vinculados ao Desenvolvimento: além da concessão do "duty free, quota free", eles defenderiam um pacote substancial de ajuda para o comércio ("aid-for-trade"), entre outras iniciativas (BRIDGES, 2005d).

Chegou-se a alegar que o entusiasmo da UE pelo "pacote de Desenvolvimento" era uma tentativa de desviar as críticas pela sua recusa em cortar suas tarifas para produtos agrícolas (BRIDGES, 2005g). De todo modo, à medida que a Conferência se aproximava, vários Membros passaram a vislumbrar e aceitar como possível resultado de Hong Kong um pacote de Desenvolvimento (VANGRASSTEK, 2013).

Embora, naturalmente, não fossem contrários a avanços nessa temática (BRIDGES, 2005h), às vésperas de Hong Kong nove PEDs, incluindo Brasil, China e África do Sul, criticaram os países ricos por haverem, segundo eles, "sequestrado" o debate sobre o Desenvolvimento. Esse grupo de países argumentava que o resultado mais importante para o Desenvolvimento que a Rodada Doha poderia produzir seria a redução substancial, por parte dos PDs, das tarifas e subsídios para produtos agrícolas, bem como das tarifas para produtos manufaturados altamente protegidos, sem que concessões onerosas fossem exigidas em troca (BRIDGES, 2005g).

Em 26 de novembro, foi circulada a primeira versão do draft de Declaração Ministerial, preparado pelo DG Lamy e pela Embaixadora Amina Mohamed, do Quênia, Chair do Conselho Geral da OMC. Após comentários dos Membros e ajustes nas seções sobre Serviços, Agricultura e NAMA, o Conselho Geral endossou, em 2 de dezembro, uma nova versão. O draft de Declaração aprovado pelo Conselho tinha diversos espaços em branco, para serem preenchidos pelos Ministros, em Hong Kong, com as datas limites em que seriam acordadas as "modalidades completas" para Agricultura e NAMA; apontava alguns pontos de convergência nesses temas, em dispositivos não vinculantes denominados "hipóteses de trabalho" ("working hypothesis"); e 
trazia, como anexos, os relatórios submetidos pelos Chairs dos diversos grupos negociadores em Genebra - Agricultura, NAMA, Serviços, Regras, Facilitação de Comércio e Tratamento Especial e Diferenciado - com a ressalva de que, excetuado o texto sobre Facilitação de Comércio, tratava-se de meros reports, e não de textos consensuados (BRIDGES, 2005i).

Acordou-se que, além do draft, seria enviada aos Ministros participantes da Conferência Ministerial de Hong Kong uma lista de perguntas a respeito das negociações em Agricultura e NAMA. As perguntas deveriam servir para orientar o debate em Hong Kong, e coincidiam, em larga medida, com os aspectos que os Chairs dos dois grupos haviam apontado, em seus relatórios, como aqueles em que seria necessária orientação ministerial (BRIDGES, 2005i).

Em Agricultura, os Membros permaneciam divididos em relação à dimensão do corte nas tarifas; a quantos produtos seriam excetuados, total ou parcialmente, das reduções tarifárias; e a como seriam estabelecidos os tetos tarifários. A UE insistia que cortes tarifários excessivos iriam erodir as preferências tarifárias ${ }^{65}$ conferidas a diversos PEDs, com efeitos devastadores para esses países, ao passo que Brasil e EUA consideravam que a UE, na verdade, agia em interesse próprio. Em 3 de dezembro, os Ministros das FIPs concordaram que buscariam obter consenso quanto a uma data para a eliminação dos subsídios à exportação até $1^{\circ}$ de março de 2006 (BRIDGES, $2005 j$ ).

Em NAMA, o draft trazia uma hipótese de trabalho que mencionava uma abordagem com a "fórmula suíça"66 para a redução tarifária, mas permaneciam as diferenças quanto às flexibilidades que estariam disponíveis para os PEDs e ao tratamento a ser conferido às tarifas não consolidadas. A poucos dias da reunião, Brasil e Índia indicaram que, diante de uma redução mais profunda nas tarifas e nos subsídios agrícolas dos EUA e da UE, poderiam aceitar um corte de até $50 \%$ nas tarifas de bens industriais (BRIDGES, 2005j).

\footnotetext{
${ }^{65}$ O Sistema Geral de Preferências (SGP) possibilita que determinados produtos originários de PEDs, especialmente os PMDRs, recebam redução ou isenção de tarifas, para além da tarifa da Nação Mais Favorecida (NMF). Atualmente, os seguintes membros da OMC oferecem preferências com base no SGP: Austrália, Belarus, Bulgária, Canadá, Estônia, UE, Japão, Nova Zealândia, Noruega, Russia, Suíca, Turquia e EUA (UNITED NATIONS CONFERENCE ON TRADE AND DEVELOPMENT [UNCTAD], [s.d.]). Nesse sentido, eventual extensão da remoção de barreiras para o âmbito multilateral tenderia a reduzir as vantagens relativas desses PEDs no acesso a tais mercados (ALEXANDRAKI, 2005).

${ }^{66}$ A chamada "fórmula suíça" é um modelo matemático de redução tarifária, inicialmente proposto pela Suíça durante as negociações da Rodada Tóquio. Ela segue a forma $Z=A X /(A+X)$, onde $X$ é a tarifa inicial do país; A é a tarifa máxima final e o coeficiente acordado para representar o nível de redução; e Z é a tarifa final resultante. Sua característica fundamental é que as taxas iniciais maiores tendem a sofrer reduções mais substantivas do que as taxas iniciais menores, uma vez que a fórmula foi sugerida levando em consideração que as últimas são menos distorcivas ao comércio do que as primeiras (EUROPEAN COMISSION, 2005).
} 
Em Serviços, o texto do draft, bem mais específico que nos outros temas, apresentava metas não vinculantes para os compromissos de liberalização a serem apresentados pelos Membros, bem como para um processo plurilateral de pedidos-ofertas (que contrastava com o modelo tradicional, bilateral). Na Conferência, seria discutido o status do anexo de Serviços, que seguia aos Ministros entre colchetes (o que, na linguagem dos negociadores, significava texto não acordado) (BRIDGES, 2005j).

Quanto ao "pacote de Desenvolvimento", que havia sido classificado pelo DG Lamy como o terceiro item mais controverso da Conferência (depois de Agricultura e NAMA), não havia sido possível acordar com antecedência nenhuma das versões das cinco propostas de acordos previstas no anexo do draft de Declaração Ministerial. A mais destacada dessas propostas era a que previa que PDs, e PEDs "declaring themselves in a position to do so" concederiam acesso sem tarifas e sem quotas às exportações provenientes de PMDRs; isso ocorreria, no máximo, até o final da Rodada, havendo a possibilidade uma "colheita antecipada". Discutir-se-ia, também, o aumento do financiamento destinado a melhorar a capacidade dos países em desenvolvimento de participarem do comércio internacional, denominado ajuda para o comércio ("aid-for-trade").

Além disso, antes da Conferência havia sido possível acordar dois potenciais elementos de um Pacote para o Desenvolvimento: a extensão de sete anos e meio para os PMDRs cumprirem com a maior parte das regras do Acordo TRIPS, e a emenda que transpunha a esse mesmo acordo a permissão para países com capacidade insuficiente de produzir medicamentos importarem tais produtos sob licenciamento compulsório (BRIDGES, 2005j).

Finalmente, quanto ao Algodão, em resposta a uma série de propostas do Cotton 4, a UE havia sugerido que os Membros acordassem, em Hong Kong, reduções substanciais nas tarifas e no apoio doméstico ao algodão, assim como com a eliminação dos subsídios à exportação, em ritmo mais acelerado que os demais setores cobertos pelas negociações em Agricultura. Os EUA, a seu turno, haviam declarado que a única colheita antecipada com a qual concordariam seria a implementação acelerada da eliminação dos subsídios ao algodão, mas, mesmo assim, apenas após a conclusão de um acordo amplo em Agricultura (BRIDGES, 2005j).

Em 2 de dezembro de 2005, o Secretário para o Comércio, Indústria e Tecnologia de Hong Kong, John Tsang, que seria o Chair da Sexta Conferência Ministerial, anunciou os nomes dos facilitadores que o auxiliariam, durante a Conferência, na condução dos diversos temas. O 
facilitador para as negociações sobre NAMA seria o Ministro do Comércio do Paquistão, Humayun Akhtar Khan, ao passo que Mukhisa Kityui, Ministro para o Comércio do Quênia, responderia pelas negociações sobre Agricultura, e Clement Rohee, Ministro das Relações Exteriores da Guiana (que já havia atuado como facilitador na conferência anterior), pelas questões específicas relacionadas ao Desenvolvimento, como tratamento especial e diferenciado (BRIDGES, 2005k).

Além disso, foram apontados três "facilitadores gerais" ("facilitators at large"), que ficariam responsáveis por outros temas, como Serviços e Regras: o Ministro do Comércio da Coreia, Kim Hyun-Chong; o Ministro das Relações Exteriores da Noruega, Jonas Gahr Store; e o Ministro das Relações Exteriores do Chile, Ignacio Walker (BRIDGES, 2005k).

Anunciou-se também que durante a Conferência as negociações ocorreriam em uma ampla variedade de formatos, formais e informais, com a participação de pequenos grupos ou a totalidade dos Membros. Ademais, dois períodos de uma hora cada haviam sido reservados a cada dia para que as delegações se encontrassem umas com as outras. Todos os dias haveria, além disso, pelo menos uma reunião informal de Chefes de Delegação (BRIDGES, 2005k; OMC, 2005a).

Segundo o Chair Tsang, a transparência e a inclusão seriam garantidas, isto é, todos os Membros seriam informados e representados nas consultas (OMC, 2005a). Com efeito, chamou a atenção o fato de que, em Hong Kong, ao contrário de Cancun, as reclamações relacionadas a esses aspectos virtualmente desapareceram. É possível que, do ponto de vista prático, tenha-se reconhecido a necessidade do contato do Chair da Conferência com um grupo menor de Membros, nas reuniões denominadas Green Room, para fazer avançar as negociações em uma organização composta por 149 Membros (BRIDGES, 20051).

Além disso, para ampliar o diálogo com a sociedade civil sobre que ocorria em Hong Kong, o DG Lamy manteve um diário eletrônico, em que comentava os principais acontecimentos de cada dia da Conferência Ministerial, bem como um fórum on line de discussões (LAMY, 2005b; LAMY, 2005c). Embora tenha havido protestos às margens da Conferência de Hong Kong, levados a cabo, entre outros, por grupos de agricultores sul-coreanos contrários à liberalização comercial, eles certamente foram menos violentos que aqueles observados em Seattle e em Cancun (CNN, 2005). 


\subsubsection{O dia-a-dia da Conferência de Hong Kong}

\subsubsection{Primeiro dia - Terça-feira, 13 de dezembro de 2005}

Em seu statement na sessão de abertura da Conferência, o ex-DG Supachai Panitchpakdi (então Secretário-Geral da Conferência das Nações Unidas para o Comércio e o Desenvolvimento - Unctad), transmitindo mensagem do Secretário Geral da ONU, Kofi Annan, ressaltou a centralidade dos aspectos relacionados ao desenvolvimento para o sucesso da Rodada Doha:

Development -- real gains in real peoples' lives -- remains the primary benchmark for success of the Doha Round. Whatever other smaller steps your negotiations achieve, development writ large is the standard against which your efforts will be judged (SUPACHAI, 2005, p.1).

Já o DG Lamy afirmou que, para terem sucesso em Hong Kong e incentivarem o comércio justo, os Ministros deveriam deixar de lado suas posições e seus comportamentos tradicionais, abrir-se às necessidades das outras Partes e assumir riscos:

Repeating long known positions, using negotiators' language, refusing to understand the reasons of counterparts and avoiding any risks — including political risks — will get us nowhere. Worse, it might put to risk valuable assets amassed with so much effort by our predecessors in the past. On the other hand, taking a bit of risk - a calculated risk will mean a chance for improved rules, for a level playing field, for free and fair trade in short, the best chance for development, the backbone of the Doha Round.

O DG prosseguiu:

Short of a magic wand, I can only give you my best advice: be open-minded, be bold, be courageous. Enter the cave of the tiger and leave Hong Kong with a prize in your hands - the assurance that the Doha Development Round has a real chance of coming to a happy end (LAMY, 2005d, p.1).

A despeito da fala do DG Lamy, as manifestações dos Ministros na sessão de abertura reiteraram os posicionamentos já conhecidos. O chanceler Celso Amorim ressaltou que, em grande medida, o déficit do desenvolvimento resulta da inadequação das regras que se aplicam à agricultura comparadas às que se aplicam a outras atividades econômicas, e reafirmou "All forms of distorting subsidies have to be eliminated or drastically reduced” (AMORIM, 2005, p;1)

O Comissário Europeu Peter Mandelson, a seu turno, enfatizou:

Agriculture is important. (...) But a single issue Round cannot succeed. We need more to negotiate about. That's why the success of the Round will depend on our ambition to liberalize trade in industrial goods and services, and to strengthen trade rules (MANDELSON, 2005, p.1) 
Já Robert Portman, Representante para o Comércio dos EUA, lamentou que Membros chaves se recusassem a concordar com um pacote equilibrado em Agricultura, e prosseguiu, citando nominalmente a UE:

I believe there remains only one way to break the current deadlock. It requires a convergence on reducing tariffs in the relatively protected agricultural sector worldwide. Again, I join other countries in the developed and developing world in calling for our trading partners in Europe to agree to a global formula that truly meets the Doha requirement of substantial improvement in market access (PORTMAN, 2005, p.1).

Após a sessão de abertura, o primeiro grupo a se reunir foi o de NAMA. O facilitador Khan propôs que as negociações se concentrassem em reuniões com grupos menores ou consultas com delegações individuais, de forma a permitir avanços concretos. Para garantir a transparência, ele também convocaria reuniões com a participação de todos. Sobre a importância de avançar em Hong Kong, o facilitador Khan alertou: "If we don't make progress this week we leave ourselves a monumental task next year" (WTO, 2005b).

O facilitador Rohee, do Grupo sobre Desenvolvimento, indicou que promoveria reuniões individuais com os Membros, nos chamados “confessionários” (BRIDGES, 20051).

Especificamente quanto à "ajuda para o comércio", no primeiro dia da Ministerial de Hong Kong diversos países, como Japão e UE, anunciaram novos ou maiores compromissos de financiamento. O Ministro das Finanças de Ruanda, Paul Manasseh Nshuti, ressaltou que esse tipo de ajuda deve ser considerado como doação, e não deveria prejulgar o posicionamento dos países receptores nas negociações. Em termos gerais, os Ministros concordaram que a "ajuda para o comércio" é um complemento necessário, e não um substituto, para a liberalização comercial (BRIDGES, 20051).

\subsubsection{Segundo dia-Quarta-feira, 14 de dezembro de 2005}

Na reunião de Chefes de Delegação na tarde do segundo dia, o facilitador para Agricultura, o queniano Kituyi, reportou que até aquele momento não havia tido avanços significativos (WTO, 2005c). Mais tarde, naquele mesmo dia, em uma reunião Green Room que teve a duração de quatro horas, todos os países participantes concordaram com 2010 como data para o fim dos subsídios agrícolas à exportação, à exceção da UE e da Suíça (BRIDGES, 2005m). Àquela altura, Peter Mandelson recusava-se a fixar qualquer data específica para o fim dos 
subsídios à exportação, ao argumento de que muito pouco estava sendo oferecido em troca à UE (BLUSTEIN, 2009).

Já o facilitador para NAMA, o paquistanês Khan, afirmou na reunião de Chefes de Delegação que, naquele momento, a principal diferença entre os Membros relacionava-se à ambição da abertura dos mercados de bens industriais e às flexibilidades correspondentes. Segundo ele, os delegados haviam indicado disposição para chegar a um consenso, mas seguiam sustentando posições maximalistas (WTO, 2005c).

Por sua vez, o facilitador Rohee, responsável por temas relacionados ao Desenvolvimento, informou que inicialmente se concentraria nas propostas contidas no anexo específico do draft de Declaração Ministerial, e, em particular, nas discussões sobre "duty free, quota free". Neste ponto específico o facilitador informou que, conquanto permanecesse esperançoso quanto às chances de um acordo em Hong Kong, a superação das diferenças remanescentes exigiria intervenção política no mais alto nível (WTO, 2005c).

A UE, já obrigada a conceder acesso sem tarifas e sem quotas aos PMDRs em razão da iniciativa Everything but Arms ("Tudo menos Armas") ${ }^{67}$, defendeu que os demais PDs assumissem o mesmo compromisso. Já os EUA e o Japão preferiram preservar, ainda que provisoriamente, a possibilidade de excluir certos produtos (como têxteis e arroz), além de outras flexibilidades. Por outro lado, um negociador sênior de um PED chegou a sugerir que qualquer pacote de acesso a mercados para PEDs que não incluísse todos os países e todos os produtos seria inaceitável (BRIDGES, 2005m). Quanto à entrada em vigor do compromisso, EUA defendiam que acompanhasse as demais negociações de Doha, ao passo que Índia e Brasil diziam estarem prontos para implementá-lo imediatamente (BRIDGES, 2005m).

Quanto ao fim dos subsídios ao Algodão, diversos Membros expressaram simpatia pela demanda do Cotton 4 (BRIDGES, 2005m). O discurso do Ministro do Comércio e da Indústria do Chade na sessão plenária realizada ao final do segundo dia, que aludiu ao sofrimento, à pobreza, à dignidade humana e à cooperação, foi considerado "muito comovente" pelo DG Lamy, que declarou que a OMC "is about much more than trade" (LAMY, 2005b, p.1). Os EUA, no entanto, seguiram rejeitando o compromisso com uma "colheita antecipada" na matéria (BRIDGES, 2005m).

\footnotetext{
${ }^{67}$ A iniciativa Everything But Armas foi instituída pela União Europeia em 2001 com o propósito de oferecer acesso sem tarifas e sem quotas aos produtos originários dos PMDRs (EUROPEAN COMISSION, 2014).
} 
No geral, houve poucos avanços no segundo dia da Conferência. A despeito disso, ao final do dia o DG Lamy manifestou estar tranquilo e confiante quanto ao processo inclusivo de construção do consenso:

I feel calm nonetheless because I'm confident that what we're shaping has come from the bottom up, from the Members, developed and developing, small island countries, from powers like US, EU, China, India and Brazil, and also from the group of the poorest countries, who are perhaps the most eloquent of all on why we must not fail. Different interests, a myriad of signals and signs to decipher, to make sense of, before stealing a little sleep. I'm reminded of a Chinese proverb: no wind, no waves. Something is happening. A demain!

Por outro lado, considerando os poucos dias até o final da reunião, o periódico Bridges (BRIDGES, 2005, p.2) alertou para o risco de não haver tempo suficiente para se alcançar o consenso:

Negotiators and trade observers suggest that though it is almost traditional for delegations to hold their cards close to their chest until the last two or three days of the meeting, there is a risk that when they finally reveal their positions, there will not be enough time left to reach a deal.

\subsubsection{Terceiro dia - Quinta-feira, 15 de dezembro de 2005}

As negociações seguiram travadas no terceiro dia de reuniões (BRIDGES, 2005n). Na reunião de Chefes de Delegação realizada no final da tarde, o Chair Tsang informou que havia sinais de progresso, particularmente nos temas relacionados aos países de menor desenvolvimento relativo, mas que o acordo ainda estava distante em diversos itens controversos da agenda. Ao reforçar a urgência de se intensificarem os trabalhos, ele recordou que Hong Kong não lançava nem concluía uma Rodada, mas apenas levava Doha um passo mais perto da sua conclusão (WTO, 2005d).

O facilitador responsável por temas relacionados ao Desenvolvimento, Clement Rohee, relatou que os Membros caminhavam para o consenso de que o compromisso de "duty free, quota free" seria implementado "de forma duradoura" (on a lasting basis); beneficiaria a todos os PMDRs; e cobriria um percentual crescente das importações. Além disso, vislumbrava-se alguma flexibilidade na aplicação por parte dos PEDs (WTO, 2005c).

Em NAMA, o facilitador Khan lamentou a insistência nas posições arraigadas adotadas desde Genebra e a ausência de progresso significativo quanto às emendas ao draft de Declaração Ministerial (WTO, 2005d). 
Após a reunião de Chefes de Delegação, houve nova reunião Green Room. Desta vez, discutiram-se propostas de textos para diversos aspectos específicos das negociações em Agricultura, NAMA e temas relacionados ao Desenvolvimento, que haviam sido elaboradas pelos Membros a pedido do DG Lamy. Além disso, foi apresentado um draft sobre "duty free, quota free”, preparado pelo facilitador Rohee, que não excluía dos beneficiários nenhum PMDR, mas continha exceções limitadas para certos produtos e deixava em aberto a data de implementação da medida (BRIDGES, 2005n).

Apesar dos esforços para dar mais substância ao draft de Declaração Ministerial, o facilitador Kituyi, responsável por supervisionar as discussões em Agricultura, cancelou a reunião plenária sobre a matéria (BRIDGES, 2005n). Em uma conferência à imprensa, o G20 enfatizou que o estabelecimento de uma data-limite para o fim dos subsídios à exportação era um dos poucos "entregáveis” em matéria de Agricultura na Conferência de Hong Kong e, portanto, enviaria um sinal importante ao público quanto ao compromisso dos Membros da OMC com a Rodada Doha. Eles também enfatizaram que a maioria dos países desenvolvidos e em desenvolvimento haviam endossado 2010 como essa data-limite (BRIDGES, 2005n).

Nas discussões sobre Serviços, o G90, que inclui os países da África, Caribe e Pacífico, o grupo de PMDRs e a União Africana, circulou um texto alternativo para o Anexo sobre a matéria. O novo texto reforçava referências aos interesses dos PEDs, enfatizando a abertura em Modo 4 (movimento temporário de pessoas) (BRIDGES, 2005n).

Nesse mesmo dia, mais cedo, um negociador de um PED teria dito que a UE, os EUA e o DG Lamy estavam exercendo “enorme pressão” sobre alguns dos países do G90 com o propósito de dissuadi-los de alterar o Anexo de Serviços. A UE teria alertado, em reuniões bilaterais, que não haveria Declaração Ministerial se os compromissos previstos no referido Anexo fossem enfraquecidos (para o negociador que fez o relato, essa seria uma forma de a UE evitar compromissos substanciais em Agricultura). Ao mesmo tempo, o DG Lamy teria sugerido que alterar o Anexo de Serviços poderia comprometer a Conferência. Finalmente, os EUA estariam alertando oficiais das capitais do G90 para não pressionarem por mudanças no texto (BRIDGES, 2005n).

2.4.1.4 Quarto dia-Sexta-feira, 16 de dezembro de 2005 
Na reunião de Chefes de Delegação do quarto dia da Conferência, o Chair Tsang informou que, a partir das contribuições dos Membros reunidas pelos facilitadores, um novo draft de Declaração Ministerial seria preparado e circulado no dia seguinte (sábado, 17 de dezembro). O Chair assegurou que, nesta nova fase, o processo continuaria bottom-up, e que, a exemplo da preparação para a Conferência, em Genebra, não haveria surpresas. Ele informou ainda que após a divulgação do texto haveria nova reunião de chefes de delegação, além de consultas adicionais promovidas pelo DG Lamy, com vistas a solucionar as diferenças que permanecessem (WTO, 2005e).

Em Agricultura, o foco das consultas conduzidas por Tsang seria o estabelecimento de uma data para o fim dos subsídios à exportação, tema em que as divergências persistiam (WTO, 2005d), bem como, junto com Lamy, a construção de "vínculos positivos" (positive linkages) entre as negociações em Agricultura e NAMA (WTO, 2005e). Adicionalmente, o facilitador para o tema de Agricultura, o queniano Kituyi, apontou uma possível convergência no tema do Algodão (BRIDGES, 2005o).

Já o facilitador para as questões relacionadas ao Desenvolvimento, Clement Rohee, da Guiana, informou, na mesma reunião de Chefes de Delegação, que havia preparado um texto de compromisso sobre "duty free, quota free". O texto havia sido circulado na noite anterior, e foi discutido entre os Membros na manhã do quarto dia, com sugestões de redação apresentadas pelo Canadá, Quênia, Paquistão, Malawi, Suíça, Trinidad e Tobago - em nome da Caricom ${ }^{68}$ - e Zâmbia - em nome dos PMDRs. As discussões prosseguiriam na noite do quarto dia (WTO, 2005e).

O facilitador para o tema de Serviços, o ministro Kim, da Coreia, não participou da reunião de Chefes de Delegação do quarto dia. De todo modo, as discussões sobre o tema ao longo do dia evidenciaram a manutenção das divergências: na reunião convocada pelo facilitador Kim para discutir o assunto, um grupo de 26 países (BRIDGES, 2005o) defendeu a manutenção do anexo de Serviços do draft preparado e distribuído antes da Conferência, enquanto outros, como os EUA e a UE (BRIDGES, 2005o), sustentaram que era necessário fortalecer os objetivos

\footnotetext{
${ }^{68}$ A Comunidade do Caribe (Caribbean Community - CARICOM) é um bloco econômico formado em 4 de julho de 1973. Atualmemnte, os países-membros são: Antígua e Barbuda, Bahamas, Barbados, Belize, Dominica, Granada, Guiana, Haiti, Jamaica, Montserrat, Santa Lúcia, São Cristóvão e Névis, São Vicente e Granadinas, Suriname, Trinidad e Tobago; e os membros associados são: Bermudas, Ilhas Virgens Britânicas, Ilhas Caimán e Anguilla (CARIBBEAN COMMUNITY [CARICOM], 2011).
} 
e aspectos operativos contidos no texto. Um terceiro grupo defendeu que o anexo era excessivamente prescritivo (WTO, 2005e).

Ainda no quarto dia da Conferência, ministros representando o G20, o G33 ${ }^{69}$, o grupo de países da África, Caribe e Pacífico (Grupo ACP), o grupo de PMDRs, o Grupo Africano e o grupo de economias pequenas (Small Economies) convocaram uma conferência de imprensa conjunta para anunciar seu interesse compartilhado e as suas expectativas quanto à dimensão do desenvolvimento da Rodada Doha (BRIDGES, 2005o).

Para este grande grupo, chamado por alguns de G110, "the round must result in the removal of the distortions that inhibit the export growth of developing countries and the provision of adequate policy space to ensure their sustainable socio-economic development" (BRIDGES, 2005o, p.2). Eram objetivos comuns a eliminação dos subsídios à exportação até 2010; o acesso a mercados para as exportações de PMDRs por meio da iniciativa "duty-free, quota-free"; a ajuda a certos países para combater os efeitos da erosão de preferências; e o encaminhamento adequado à questão do Algodão (BRIDGES, 2005o).

Enquanto o periódico Bridges destacou que era a primeira vez que representantes de todos os países em desenvolvimento Membros da OMC se reuniam em uma Conferência Ministerial (BRIDGES, 2005o), Guy de Jonquieres ressaltou as contradições internas dessa ampla "aliança ad hoc" de PEDs (alguns integrantes, como o Brasil, seriam beneficiados pela maior abertura, ao passo que outros - a maioria - seriam prejudicados pela erosão de preferências), e sugeriu tratarse de uma encenação, e não de um estratagema sério de negociação (JONQUIERES, 2005).

Seja como for, na visão do DG Lamy, o quarto dia de reuniões, e a longa noite que se seguiu, foram momentos tensos e difíceis, não apenas para os negociadores, mas também para os mediadores, "who have to understand each and every position in order to midwife compromises that work" (LAMY, 2005b, p.1).

\subsubsection{Quinto dia - Sábado, 17 de dezembro de 2005}

Às $14 \mathrm{~h}$ do quinto dia de reuniões, o Chair Tsang e o DG Lamy circularam, conforme anunciado na véspera, um novo draft de Declaração Ministerial. O texto incorporava avanços nas

\footnotetext{
69 O G33, liderado pela Indonésia, preocupa-se com as consequencias da liberalização comercial sobte os pequenos agricultores e agrega mais de 40 países $(\mathrm{BBC})$.
} 
discussões sobre Agricultura, NAMA e temas específicos de Desenvolvimento, incluindo "dutyfree, quota-free", e resultou de uma longa noite de trabalho dos Ministros, particularmente do grupo consultivo do Chair reunido como Green Room, que contou com 30 a 40 delegações, incluindo representantes de todos os grupos e demais atores importantes das negociações (WTO, 2005f).

Entre as alterações do draft, haviam sido introduzidas duas alternativas, ainda encolchetadas, para o fim dos subsídios às exportações agrícolas: até 2010; ou cinco anos após o início da implementação da Rodada Doha - neste caso, considerando-se que a implementação tivesse início em 2008, a eliminação dos subsídios deveria ocorrer até 2013 (BRIDGES, 2005p).

Para o Algodão, o draft previa expressamente o fim dos subsídios à exportação até 2006. Já para os subsídios domésticos distorcivos, estabelecia que o apoio deveria ser reduzido mais rápido, e mais profundamente, que o previsto na fórmula que viesse a ser consensuada para a redução dos subsídios agrícolas em geral (essa relação implicava, portanto, que não haveria “colheita antecipada" para o Algodão) (BRIDGES, 2005p).

Quanto ao "duty-free, quota-free", o draft não detalhava as exceções, nem os períodos de implementação. O draft tampouco definia a data-limite para o acordo a respeito dos números e da estrutura para os cortes de tarifas e subsídios, embora sugerisse março de 2006 (BRIDGES, 2005p).

Para NAMA, o draft referia-se a uma "fórmula suíça" para redução tarifária, mas não especificava os coeficientes que a comporiam. Além disso, vinculava expressamente os níveis de ambição para os resultados obtidos em Agricultura e NAMA (BRIDGES, 2005p).

Enquanto o Ministro do Comércio da Índia, Kamal Nath julgou positivo manter-se a abertura para adoção de coeficientes múltiplos, o canadense Jim Peterson manifestou preferência por uma "fórmula suíça" com apenas dois coeficientes - um para PDs e outro para PEDs. Já o chanceler Celso Amorim afirmou que era necessário explicitar o princípio da "reciprocidade menos que plena" (less than full reciprocity) (BRIDGES, 2005p).

Finalmente, o anexo sobre Serviços reafirmou o caráter não prescritivo de suas recomendações. Além disso, em lugar de obrigar os Membros a ingressar em negociações plurilaterais de acesso a mercados, o novo texto prescrevia aos Membros apenas que deveriam considerar as solicitações para ingressar nessas negociações (BRIDGES, 2005p). 
$\mathrm{Na}$ reunião de chefes de delegação do final da tarde do mesmo dia, o Chair Tsang ressaltou que os Ministros deveriam fornecer uma base clara e viável para as discussões do ano seguinte, e incitou a todos que refletissem sobre a responsabilidade compartilhada pelo sucesso, ou pelo fracasso, da reunião (WTO, 2005f).

Mais de 60 Membros fizeram uso da palavra durante a reunião, muitos para elogiar o processo bottom-up de elaboração do novo draft (ou seja, partindo de propostas dos Membros, e não dos Chairs (WTO, 2005f). Alguns Membros ressaltaram que o draft representava um passo adiante, mas modesto, e deixava para 2006 parte substancial do trabalho. Membros destacaram ainda que era necessário capturar o progresso alcançado até aquele momento e produzir resultados, "for the credibility of the WTO" ((WTO, 2005f, p.1).

Por outro lado, outras delegações declararam-se desapontadas com o draft. Em diversos temas, incluindo Serviços, Agricultura e NAMA, enquanto alguns Membros lamentaram a falta de ambição do texto, outros julgavam o nível de ambição alto demais.

No geral, de todo modo, o draft foi considerado modesto, mas admissível. Nesse sentido, uma delegação ressaltou: "the text fell short of many of its aspirations but it was minimally acceptable" (WTO, 2005f, p.1). Os Ministros teriam até as 6 h30 da manhã do dia seguinte (domingo, 18 de dezembro) para solucionar o máximo possível de questões pendentes e apresentar suas emendas ao draft (BRIDGES, 2005p).

Seguiu-se mais uma noite de discussões acaloradas. Durante as oito horas de reunião no Green Room, ficou evidente o impasse entre o G20 e a UE: enquanto aquele grupo, liderado pelo chanceler Celso Amorim, exigia 2010 como data limite para fim dos subsídios agrícolas, o Comissário Europeu, Peter Mandelson, sustentava não poder aceitar data anterior a 2013 - nesta data, previa-se, a UE já teria eliminado a maior parte desses subsídios como decorrência de reformas internas (JONQUIERES, 2005).

Segundo Paul Blustein, apenas após intervenção do norte-americano Robert Portman, que teria literalmente implorado para que o chanceler brasileiro aceitasse negociar um acordo de compromisso com os europeus, foi possível superar o impasse: acordou-se que os subsídios à exportação teriam 2013 como data limite, mas com a condição de que parte substancial fosse eliminada antes disso (BLUSTEIN, 2009); mais precisamente, até o final da primeira metade do período. É curioso o observado por Bhagwati (2005): durante a Conferência, China e Índia evitaram confrontar diretamente a UE sobre este tema, a despeito de integrarem o G20. 


\subsubsection{Sexto dia-Domingo, 18 de dezembro de 2005}

O esforço final dos negociadores deu resultado: na manhã do sexto e último dia de reuniões tinha-se a um texto consensuado.

Assim, a Sexta Conferência Ministerial da OMC resultou na adoção de uma longa Declaração Ministerial (44 páginas, excluídos os anexos) que, partindo do framework contido no "Pacote de Julho", tinha como principais destaques as duas ações voltadas para o desenvolvimento: as iniciativas "duty-free, quota-free" e "ajuda para o comércio"70.

Em relação aos temas mais controversos, o principal avanço foi, em Agricultura, a aceitação por parte da UE, nos últimos momentos da reunião, da eliminação de todas as formas de subsídios à exportação, ainda que a data acordada tenha sido o final de 2013, e não 2010, como demandava o $\mathrm{G} 20^{71}$.

Como a UE, os EUA também fizeram concessões, e admitiram que a Declaração Ministerial contivesse os seguintes compromissos no tema do Algodão: a) eliminar até 2006 todas as formas de subsídio concedido pelos PDs às exportações de algodão; b) conceder acesso aos mercados de PDs, livre de tarifas e de quotas, às exportações de algodão provenientes de PMDRs; e c) reduzir os subsídios domésticos distorcivos ao algodão de maneira mais ambiciosa e mais rápida do que o que viesse a ser acordado para a redução dos subsídios domésticos em geral.

Lee e Wilkinson (2007) destacam, citando Stiglitz e Charlton, que o recuo dos EUA era mais simbólico que substantivo, já que, entre outras razões, a derrota recente do país no Órgão de Solução de Controvérsias da OMC já os impelia a retirar os subsídios às exportações de algodão ${ }^{72}$ (LEE; WILKINSON, 2007).

A exemplo do "Pacote de Julho", a Declaração Ministerial de Hong Kong previu uma série de prazos ambiciosos: as modalidades em Agricultura e NAMA, por exemplo, deveriam ser

\footnotetext{
${ }^{70}$ Como se recorda, essas ações previam, respectivamente, que PDs, e PEDs que se declarassem em condições de fazê-lo, franqueariam seus mercados aos produtos provenientes de PMDRs ("duty-free, quota-free"), além do financiamento aos PEDs, particularmente PMDRs, para expandir a sua participação no comércio, promovendo, ao mesmo tempo, a implementação e os benefícios advindos dos acordos da OMC ("ajuda para o comércio").

${ }^{71}$ A despeito da resistência de Mandelson durante a Conferência, havia a expectativa de que a UE aceitasse 2010 como data limite, já que a própria UE, em entrevistas, havia sinalizado que isso seria razoável (LEE; WILKINSON, 2007).

${ }^{72} \square$ Os autores referem-se ao caso Subsidies in Upland Cotton (DS267), vencido pelo Brasil.
} 
estabelecidas até 30 de abril de 2006, e as primeiras versões das listas de compromissos eram esperadas até 31 de julho de 2006. Toda a Rodada Doha deveria ser concluída, com sucesso, até o final 2006.

Para o então DG da OMC, Pascal Lamy, a reunião recolocou a OMC "de volta nos trilhos": após a Conferência, a Rodada Doha estaria 60\% completa, comparado a 55\% antes. Além disso, Hong Kong teria contribuído para reequilibrar a agenda da OMC em favor dos países mais pobres, além de reunir a energia política necessária para a conclusão da Rodada (THE ECONOMIST, 2005).

Para Blustein, o consenso em torno de uma data limite para a eliminação dos subsídios às exportações agrícolas foi o que tornou possível acordar o texto da Declaração Ministerial, “thereby keeping the Doha Round from sliding back" (BLUSTEIN, 2009, p. 220).

Já na avaliação de Stuart Eizenstat e Christopher Roberts, o resultado positivo em Hong Kong decorreu diretamente do draft habilmente preparado pelo DG Lamy e circulado na tarde do sábado: "It was in fact the Director General Lamy's draft proposal that kept the Hong Kong meeting from failing”, afirmaram (EIZENSTAT; ROBERTS, 2006, p. 5). Para os autores, o draft foi capaz de capturar o consenso que era necessário e de pressionar o suficiente para garantir avanços, sem, contudo, forçar a resolução prematura de questões ainda não suficientemente maduras.

Já Bhagwati faz referência às longas e árduas horas de discussões durante a Conferência e associa o consenso alcançado à determinação dos negociadores: "Six days and sleepless nights in Hong Kong characterised their determination not to fail.” (BHAGWATI, 2005, p1). Para este autor, os resultados da Conferência representavam passos significativos em direção à conclusão da Rodada Doha.

\subsection{Desdobramentos posteriores (do pós-Hong Kong a Nairobi)}

Passada a celebração pelos resultados positivos, embora modestos, de Hong Kong, as negociações desaceleraram-se quase que imediatamente. Nenhum dos prazos previstos na Declaração Ministerial de Hong Kong foi cumprido. Ao contrário: em julho de 2006 as negociações foram suspensas, por recomendação do próprio DG. Em 2007, pela primeira vez (e 
única até hoje), a Conferência Ministerial bianual prevista no Acordo de Marraqueche não se realizou (VANGRASSTEK, 2013).

Em julho de 2008, em torno de setenta Membros reuniram-se novamente em uma miniministerial realizada em Genebra. Embora cerca de 30 participantes tenham acompanhado as reuniões do Green Room, a maior parte das negociações deu-se incialmente em um grupo mais restrito de sete Membros (G7) - Austrália, Brasil, China, EUA, Índia, Japão e UE - que, em alguns casos, reduziu-se ainda mais, com a ausência de China e Japão (VANGRASSTEK, 2013).

As negociações deram-se com base em um draft de apenas uma página, de autoria do DG Lamy. Do G7, o draft foi inicialmente rejeitado apenas pela Índia. Ao longo das discussões, esteve-se perto do consenso em uma série de temas centrais para as negociações, como modalidades em Agricultura e NAMA. VanGrasstek ressalta que esteve-se "closer than ever to completing the round" (2013, p. 447).

Diferenças em torno do tema das salvaguardas especiais (SSM), no entanto, envolvendo interesses opostos da Índia e dos EUA, levaram ao impasse nas discussões. Ao final da reunião, esses dois países foram apontados como os principais responsáveis pelo resultado negativo (VANGRASSTEK, 2013 , p. 453).

As duas Conferencias Ministeriais organizadas após o colapso da mini-ministerial de julho de 2008, realizadas em Genebra em 2009 e 2011, despertaram expectativas particularmente baixas: não se esperavam decisões importantes ou mesmo sérias negociações. "It is a 'non-event' by design. (...) A 'housekeeping exercise'”, destacou o periódico BRIDGES (2009, p.1) a respeito da Sétima Conferência Ministerial. Quanto à Oitava Conferência Ministerial, o mesmo periódico apontou: "[o]ne of the few areas where members have been able to reach consensus, it seems, is that this year's event is not to be a Doha Round negotiating ministerial" (BRIDGES, 2011, p.1). Nenhuma dessas duas Conferências resultou na adoção de Declarações Ministeriais.

A Nona Conferência Ministerial da OMC realizou-se em dezembro de 2013, em Bali, Indonésia. Como resultado das negociações, foi acordado o "Pacote de Bali", um conjunto de decisões com os objetivos declarados de simplificar as operações comerciais, oferecer aos PEDs mais opções para garantir a segurança alimentar, incrementar o comércio de PMDRs e, de maneira geral, incentivar o desenvolvimento.

A principal decisão do Pacote de Bali foi o Acordo de Facilitação de Comércio, que prevê a simplificação de regras aduaneiras, como a redução do tempo necessário para a movimentação 
de containers, a garantia de procedimentos padronizados para o trânsito de mercadorias e a eliminação de exigências burocráticas nas fronteiras. Algumas estimativas apontam que o acordo tem o potencial de acrescentar US\$ 1 trilhão à economia mundial e de gerar 21 milhões de empregos, sendo 18 milhões em PEDs (MILES, 2014).

Apesar de em certos momentos a Conferência parecer caminhar para o impasse, nas últimas horas da reunião (que estendeu-se um dia além do previsto) as posições de todos os Membros convergiram e o "Pacote de Bali" foi aprovado. O consenso final foi considerado "extraordinário" pelo Chair da conferência e Embaixador da Indonésia, Gita Wirjawan (2013). O periódico britânico Financial Times afirmou: "The breakthrough helps restore the reputation of the WTO as a dealmaker. (...) As the surprise in Bali shows, multilateralism still has much potential" (FINANCIAL TIMES, 2013, p.1).

O seguimento da reunião mostrou-se, contudo, um desafio. A recusa do recém-eleito governo da Índia em adotar, dentro do prazo que se encerrou em 31 de julho de 2014, o Acordo de Facilitação de Comércio aprovado em dezembro de 2013, bloqueou temporariamente (devido à regra do consenso) a adoção de todo o "Pacote de Bali" por parte dos Membros da OMC, incluindo o Acordo de Facilitação de Comércio. O impasse foi superado quatro meses mais tarde, após entendimento bilateral entre os EUA e a Índia. Assim, em 27 de novembro de 2014, o Conselho Geral da OMC adotou três decisões, prevendo: a) a adoção do Acordo de Facilitação de Comércio; b) esclarecimentos sobre o teor da decisão de Bali a respeito da formação de estoques públicos para fins de segurança alimentar, bem como a negociação, até dezembro de 2015, de um acordo permanente sobre a matéria; e c) a adoção de um programa de trabalho pós-Bali, sobre as questões remanescentes da Agenda de Doha, até julho de 2015.

Finalmente, a Décima Conferência Ministerial da OMC foi realizada em Nairobi, Quênia, em dezembro de 2015. Após cinco dias de intensas negociações, foi aprovado o "Pacote de Nairóbi”, que contém avanços em matéria de Agricultura e Desenvolvimento. Além disso, celebrou-se o encerramento bem-sucedido das negociações para ampliação da cobertura do acordo plurilateral que cobre bens de tecnologia da informação. Finalmente, mas não menos importante, a reunião expôs de forma inequívoca a divergência entre os membros quanto ao futuro da negociações comerciais multilaterais.

Em Agricultura, o Pacote de Nairóbi inclui novas decisões ministeriais, todas elas legalmente vinculantes, a respeito de: um mecanismo de salvaguarda especial para PEDs; 
subsídios à exportação e outros elementos "da concorrência na exportação" (créditos à exportação, garantias de créditos à exportação e outros tipos de financiamento à exportação, empresas estatais exportadoras e ajuda alimentar) ${ }^{73}$; algodão; e, finalmente, estoques públicos para fins de segurança alimentar - neste último ponto, reafirmaram-se as decisões de Bali e de novembro de 2014, e estabeleceu-se mandato para negociações sobre a matéria (separadas da Rodada Doha) no âmbito do Comitê de Agricultura da OMC (BRIDGES, 2015).

Um dos resultados substanciais de Nairobi foi o anúncio da conclusão das negociações entre 53 membros da OMC para expandir a cobertura de produtos do Acordo de Tecnologia da Informação (ITA), acordo plurilateral originalmente negociado em 1996 cuja expansão vinha sendo negociada há três anos, em paralelo com as negociações da Rodada de Doha. As tarifas reduzidas serão estendidas a todos os Membros da OMC (BRIDGES, 2015).

O pacote em Agricultura foi celebrado pelo DG Azevêdo como o resultado mais significativo neste tema nos vinte anos da OMC. O acordo sobre concorrência nas exportações de produtos agrícolas, em particular, foi comemorado como algo desejado há 60 anos, quando os primeiros compromissos multilaterais nessa matéria foram acordados para bens industriais. Da mesma forma, o chamado ITA II foi comemorado como sendo o primeiro acordo de redução de tarifas negociado desde a criação da OMC (BRIDGES, 2015).

Quanto à dimensão do Desenvolvimento, a reunião de Nairobi resultou na adoção de um conjunto de disposições multilaterais sobre regras de origem preferenciais para PMDRs, assim como uma nova decisão sobre o waver de serviços para esse mesmo grupo de países (BRIDGES, 2015).

Entretanto, no que diz respeito ao futuro da Rodada Doha, a Declaração Ministerial de Nairobi evidenciou claras diferenças entre os Membros, que, ao invés de acordarem uma linguagem consensuada, "concordaram em discordar" sobre o futuro do braço negociador da OMC:

We recognize that many Members reaffirm the Doha Development Agenda, and the Declarations and Decisions adopted at Doha and at the Ministerial Conferences held since then, and reaffirm their full commitment to conclude the DDA on that basis. Other Members do not reaffirm the Doha mandates, as they believe new approaches are

\footnotetext{
${ }^{73}$ Segundo o periódico Bridges (2015), embora a UE tenha interrompido os subsídios à exportação para a maioria dos produtos, Suíça, Noruega e Canadá ainda notificam apoio à $\mathrm{OMC}$, e alguns países em desenvolvimento, como a Índia e a Turquia, também fornecem este tipo de apoio, mas não formalmente notificado ao órgão de comércio. O pacote de Nairobi prevê a eliminação imediata dos subsídios à exportação remanescentes dos países desenvolvidos o impasse da Rodada Doha fez com que o prazo de 2013, acordado na Conferência Ministerial de Honk Kong, fosse perdido - e, para os países em desenvolvimento, até 2018, e, no caso do algodão, até 2017.
} 
necessary to achieve meaningful outcomes in multilateral negotiations. Members have different views on how to address the negotiations (BRIDGES, 2015, p.1).

Em breve, portanto, os Membros da OMC terão que escolher entre seguirem orientandose pelo mandato negociador de Doha ou buscarem "novas abordagens" para impulsionar as negociações. A esse respeito, o DG Azevêdo declarou, em seu discurso de encerramento da Conferência:

Members must decide — the world must decide — about the future of this organization. The world must decide what path this organization should take. Inaction would itself be a decision. And I believe the price of inaction is too high (AZEVÊDO, 2015, p.1).

Tendo sido apresentado o contexto das negociações da Rodada Doha da OMC, e reconstruídos os acontecimentos e o comportamento dos atores na preparação e durante a Conferência de Cancun, em 2003, e a Conferência de Hong Kong, em 2005, no próximo capítulo as três hipóteses desenvolvidas por John Odell (2009) serão testadas por meio da sua aplicação a esses casos. 


\section{Aplicação das hipóteses aos casos}

Neste capítulo, as três hipóteses elaboradas por Odell (2009) para explicar as negociações comerciais internacionais serão aplicadas aos casos descritos no capítulo anterior, a saber, a Quinta Conferência Ministerial da OMC, realizada em Cancun, em 2003, e a Sexta Conferência Ministerial da OMC, realizada em Hong Kong, em 2005.

\subsection{Primeira hipótese}

A primeira hipótese é a de que se uma parte percebe que a melhor alternativa ao acordo (BATNA) piorou, o seu negociador mudará a estratégia no sentido de reduzir as demandas, suavizar as táticas distributivas e acrescentar táticas integrativas. Em sentido inverso, a percepção de melhora na BATNA direcionará a estratégia para o sentido contrário, em média, e outras circunstâncias mantidas constantes (ODELL, 2009). Esta hipótese seria desconfirmada pela demonstração empírica de que os negociadores em geral utilizam mais táticas distributivas como reação a uma piora na BATNA, ou vice-versa (ODELL, 2009) ${ }^{74}$.

\subsubsection{Conferência Ministerial de Cancun}

Como visto, a Quinta Conferência Ministerial da OMC, realizada em Cancun, em 2003, tinha o propósito de servir como uma "avaliação de meio de período" da Rodada Doha, lançada em 2001 com a previsão de ser concluída em 2005.

A agenda da reunião era constituída por uma série de temas controversos, que tinham uma característica comum: era possível contrapor, em cada um deles, posições antagônicas de países desenvolvidos (PDs) e de países em desenvolvimento (PEDs). O apelo de Pascal Lamy (então Comissário Europeu para o Comércio) em seu discurso na Cerimônia de Abertura, solicitando que se evitasse transformar a reunião em um confronto Norte-Sul, foi em vão: a oposição entre PDs e PEDs foi, sem dúvida, o principal traço da Conferência.

\footnotetext{
${ }^{74}$ Uma explicação mais detalhada das três hipóteses é encontrada na segunda parte do primeiro capítulo deste trabalho.
} 
Agricultura foi o tema em que essa dinâmica tornou-se mais evidente, com a formação do G20 e a oposição firme e proativa da nova coalisão à posição conservadora defendida por EUA e UE. Mas também nas outras matérias era possível perceber com clareza a cisão Norte-Sul: em NAMA, a proposta ambiciosa apresentada por UE, EUA e Canadá antes da Conferência foi rejeitada pelos PEDs; nos "Temas de Cingapura" os principais PDs demandantes - UE, Japão e Coreia do Sul - contrapunham-se à Índia e a outros PEDs, que insistiam no "consenso explícito" para o lançamento das negociações e se opunham a que esse lançamento ocorresse em Cancun; finalmente, no tema do Algodão, Benin, Burkina Faso, Mali e Chade demandavam o fim dos subsídios ao produto concedidos pelos PDs, notadamente os EUA, e exgiam compensação pelos impactos negativos causados a seus cotonicultores.

O clima de confronto refletiu-se na adoção de estratégias puramente distributivas por parte dos negociadores. No tema do Algodão, os EUA insistiram na proposta de diversificação de produção por parte dos países africanos, atitude que foi interpretada como evidência de que os norte-americanos não levavam as demandas africanas a sério.

Já em Agricultura, EUA e UE reagiram à oposição do G20 tentando enfraquecer a coalisão; no caso dos EUA, entre os incentivos apresentados estaria a promessa de negociação de Acordos de Livre Comércio com os países que aceitassem deixar o grupo. O G20, por sua vez, também, recorreu a tática reivindicadora de valor, uma vez que sua proposta, como reconhecido mais tarde, não incluía concessões por parte dos PEDs.

De uma forma geral, PDs exigiam ganhos em NAMA ou nos "Temas de Cingapura" antes de fazer concessões em Agricultura. Do lado oposto, PEDs sustentavam que não cederiam em NAMA ou nos "Temas de Cingapura" caso não houvesse avanços em Agricultura. Com execção da flexibilização demonstrada pela UE em relação aos "Temas de Cingapura", já ao final da reunião, essas posições maximalistas não se alteraram no decorrer da Conferência.

Cabe ressaltar que a vinculação, ou linkage, entre temas é uma característica das negociações como as da OMC, que seguem o princípio do single undertaking. Entretanto, para que a negociação seja bem-sucedida, pressupõe-se que as partes negociadoras estejam dispostas a fazer concessões mútuas, ou trade offs, de forma que, ao final da negociação, as perdas relativas em uma matéria sejam compensadas pelos ganhos relativos em outra. Em Cancun, aparentemente, essa disposição não estava presente. 
Trata-se de situação bem diferente da encontrada dois anos antes, na Conferência de Doha. Ali era evidente a disposição para negociar e fazer as concessões necessárias para a obtenção do consenso. Ao final daquela reunião, os EUA aceitaram o reexame das regras sobre antidumping, subsídios e medidas compensatórias, além de uma declaração em separado sobre TRIPS e saúde pública, demandada pelos PEDs; a UE admitiu que se mencionasse o objetivo de eliminar os subsídios agrícolas à exportação; e a Índia aceitou a inclusão dos "Temas de Cingapura" no texto final, ainda que com a ressalva de que o lançamento das negociações dependeria de "consenso explícito" entre os Membros da OMC.

Mas o que mudou entre Doha e Cancun? Essencialmente, o fracasso em Seattle e os questionamentos posteriores a respeito da viabilidade e da eficiência da OMC tornaram imprescindível um resultado positivo em Doha. Além disso, os atentados de 11 de setembro e o início da "Guerra ao Terror", poucas semanas antes da Conferência, deram impulso adicional à negociação: o lançamento de uma nova rodada em Doha demonstraria não apenas a vitalidade da OMC, mas da cooperação multilateral em geral. Em sentido contrário, um fracasso em Doha poderia significar a decadência não apenas do sistema multilateral de comércio, mas, em sentido mais amplo, das instituições internacionais.

Em outras palavras, em Doha, a melhor alternativa ao acordo - BATNA - era muito pouco atraente ${ }^{75}$, o que levou à redução do ponto de resistência dos negociadores. Isso explica, conforme descrito na primeira hipótese, a redução das demandas, a suavização das táticas distributivas e a incorporação de táticas integrativas ao final da reunião.

Em Cancun a situação havia mudado. Em primeiro lugar, o lançamento da nova rodada de negociações em Doha parecia haver demonstrado de forma inequívoca o vigor da OMC. Por outro lado, em 2003 a luta contra o terrorismo encontrava-se em outra fase, com maior envolvimento das instituições internacionais, notadamente o Conselho de Segurança das Nações Unidas $^{76}$ e a Organização do Tratado do Atlântico Norte (OTAN) ${ }^{77}$. Um impasse na Conferência

\footnotetext{
${ }^{75}$ Citando Odell, McKibben (2013, p. 420) ressalta que "states' outside options are [a] factor for which a consistent and systematic empirical measure does not currently exist". Não obstante, isso não impede que seja feita uma análise qualitativa do sentido das alterações nas alternativas disposíveis ao acordo. É isso que se propõe a fazer nesta seção.

${ }^{76}$ Por exemplo, pelo trabalho do Counter-terrorism Committee instituído pela Resolução 1373, de 28 de setembro de 2001, e pelo estabelecimento, nos termos da Resolução 1386 (de 20 de dezembro de 2001) e do Acordo de Bonn, da Força Internacional de Assistência para a Segurança (ORGANIZAÇÃO DAS NAÇÕES UNIDAS [ONU], 2001a) (ONU, 2001b) (ONU, 2001c).

${ }^{77}$ A OTAN liderou a Força Internacional de Assistência para a Segurança no Afeganistão -- a missão de segurança, instituída pelo Conselho de Segurança da ONU, tinha o propósito de oferecer as condições necessárias para o estabelecimento da Administração Transicional Afegã após a queda do regime talebã.
} 
de Cancun, embora certamente não fosse desejável, não deveria trazer maiores consequências além de um atraso tolerável nas negociações da Rodada Doha.

Em resumo, a BATNA em Cancun era mais atraente do que em Doha. De uma conferência para outra, o ponto de resistência dos negociadores elevou-se, já que não havia o mesmo incentivo para fazer concessões em favor das outras delegações. Assim, e mais uma vez em conformidade com o previsto na primeira hipótese, as táticas distributivas foram mantidas até o fim da reunião, sem que houvesse a incorporação de táticas integrativas ${ }^{78}$.

\subsubsection{Conferência Ministerial de Hong Kong}

Como visto no capítulo anterior, após o fracasso em Cancun, em julho de 2004 o Conselho Geral da OMC se reuniu, em Genebra, e aprovou o "Pacote de Julho", que consistia em um framework com recomendações para as negociações em Serviços, Agricultura, NAMA e Facilitação de Comércio no âmbito da Rodada Doha. Na Sexta Conferência Ministerial da OMC, realizada em Hong Kong, em 2005, pretendia-se transformar o framework em compromissos concretos, o que possibilitaria a conclusão da Rodada no ano seguinte, 2006, apenas um ano mais tarde do que o originalmente previsto.

Assim como em Cancun, os temas em discussão em Hong Kong eram bastante controversos. Contudo, diferentemente de Cancun, não havia em todos eles uma divisão clara entre PDs e PEDs. Nas discussões sobre Agricultura, UE e EUA passaram a ocupar lados opostos: enquanto os europeus, limitados pelo mandato comunitário, defendiam posição conservadora, os norte-americanos uniram-se ao G20 (que seguia coeso) na demanda por maior abertura dos mercados agrícolas. Já nos temas para o Desenvolvimento, que ganharam relevância à medida que a Conferência se aproximava, a UE se alinhou a grande parte dos PEDs ao defender a concessão do acesso total dos PMDRs aos mercados industriais dos PDs, "sem tarifas e sem quotas", enquanto os EUA, pressionados por lobbies domésticos como o do setor têxtil, defendiam exceções ao futuro acordo. Finalmente, em NAMA e Serviços foi mantida a oposição tradicional entre PDs - demandantes - e PEDs - demandados.

\footnotetext{
${ }^{78}$ A única exceção foi a UE, que, como dito, demonstrou alguma flexibilidade em relação aos "Temas de Cingapura".
} 
Embora, como se viu, a reunião tenha tido início com posições negociadoras maximalistas e a adoção de estratégias puramente distributivas, com o avançar da Conferência as delegações mostraram-se dispostas a fazer concessões. Em Agricultura, a UE concordou com o estabelecimento de uma data limite para a eliminação de todas as formas de subsídios à exportação; já o G20 aceitou que o prazo limite fosse 2013, e não 2010, desde que parte substancial dos subsídios fosse eliminada até o final da primeira metade do período. Os EUA, por sua vez, admitiram que a Declaração Ministerial contivesse diversos compromissos no tema do Algodão (eliminação até 2006 dos subsídios de PDs à exportação de algodão; acesso aos mercados de PDs, livre de tarifas e de quotas, às exportações de algodão provenientes de PMDRs; e redução de subsídios domésticos ao algodão).

Vale destacar que a preocupação do DG Pascal Lamy e dos Membros em evitar repetir o fracasso de Cancun fez com que se ajustassem as expectativas quanto aos resultados possíveis em Hong Kong. Ainda no processo de preparação da Conferência, abandonou-se a ambição de elaboração de "modalidades completas" para as negociações em Agricultura e NAMA. Em lugar disso, passou-se a falar, como principal resultado da Conferência, em um "pacote de Desenvolvimento". Esse reenquadramento tornou possível considerar a reunião um sucesso, a despeito dos modestos resultados alcançados.

O fracasso em Hong Kong, de fato, poderia ter efeitos devastadores para as negociações comerciais multilaterais. Seria a primeira vez, na curta história da OMC, que duas Conferências Ministeriais seguidas terminariam em impasse. Além disso, deixar-se-ia uma tarefa monumental para o ano seguinte, nova meta de conclusão da Rodada. A viabilidade da Rodada, do braço negociador da OMC e, no limite, do próprio multilateralismo comercial seria seriamente questionada.

O Comissário Europeu para o Comércio, Peter Mandelson (2005), discursou sobre isso no primeiro dia da Conferência:

To stand any chance of reaching the peak next year, we need to get well beyond base camp this week. And that means moving beyond the level of ambition in the current texts. The stark alternative is that we miss our deadline, and with it the chance of a truly successful outcome. This could pose a real threat to the principle of multilateralism. We bear a heavy responsibility which all of us must discharge by being prepared to negotiate meaningfully (...) (grifo da autora)

Essa percepção era compartilhada pelo conjunto das delegações, como posteriormente destacado por Eizenstat e Roberts (2006, p. 2): 
there was a broad recognition among the 149 member governments that a collapse of the talks would be bad for everyone, from the poorest to the wealthiest countries. Negotiators recognized that a failure not only would stifle world trade important to the economic growth of all countries, but could create a mortal wound to the WTO system itself.

Por fim, caso as negociações não fossem concluídas rapidamente, correr-se-ia o risco de expirar a Trade Promotion Authority (conhecida até 2002 como Fast Track Authority) concedida pelo Congresso dos EUA ao Presidente Bush, que valeria apenas até meados de 2007, o que reduziria as chances de que um eventual acordo resultante das negociações na OMC fosse ratificado pelos EUA. Como efeito, “The Fast Track Authority conferred in the past by the US Congress on that nation's Federal Government is generalyy believed to have eased Congressional approval of trade agreements" (DESTLER apud EVENETT, 2014, p. 148). Com a aprovação do acordo por parte do Congresso norte-americano em xeque, poder-se-ia comprometer definitivamente os resultados da Rodada.

Em Hong Kong, portanto, a BATNA era menos atraente que em Cancun, o que fez os pontos de resistência recuarem. Como previsto na primeira hipótese de Odell (2009), os negociadores reduziram suas demandas (como no caso do G20 e a data limite para o fim dos subsídios às exportações agrícolas), suavizaram táticas distributivas (como a desistência da UE em vincular qualquer avanço em Agricultura a ganhos em Serviços e NAMA) e incorporaram táticas integrativas (como a aceitação por parte dos EUA em abrir seu mercado, sem tarifas e sem quotas, ao algodão dos PMDRs).

\subsection{Segunda hipótese}

A segunda hipótese é a de que as chances de superar um impasse aumentam, em média e sempre que as partes têm um objetivo comum, na medida em que as partes se afastam de políticas distributivas estritas e se aproximam de estratégias mistas-integrativas (ODELL, 2009). Esta hipótese seria desconfirmada caso se constatasse empiricamente que situações em que estratégias puramente distributivas superam impasses são mais comuns do que situações em que estratégias mistas chegam a esse resultado (ODELL, 2009, p. 7-8).

\subsubsection{Conferência Ministerial de Cancun}


Embora os "Temas de Cingapura" tenham sido o estopim para o encerramento prematuro da Conferência de Cancun, as negociações em Agricultura foram, sem dúvida, o tema central do encontro. A apresentação da proposta de framework por parte dos EUA e da UE, a menos de um mês para a Conferência, e a reação do G20, duas semanas depois, deram início a um impasse que se manteve até o final da reunião.

Como vimos, a proposta dos EUA e da UE atendia primordialmente às sensibilidades dos setores domésticos dos dois Membros, e não incorporava demandas de interesse das demais delegações, particularmente dos países com interesse ofensivo em Agricultura. A proposta não previa, por exemplo, a eliminação dos subsídios à exportação, mas apenas a redução das previsões orçamentárias e de quantum relacionadas à concessão dos subsídios - a exceção seria uma lista, a ser negociada, de produtos de interesse específico de PEDs, que seriam os únicos para os quais prever-se-ia a eliminação total dos subsídios.

Já a proposta do G20 conciliava interesses de PEDs exportadores e importadores líquidos de produtos agrícolas, e foi acusada pelos PDs de não incorporar as preocupações dos PDs. De fato, o framework exigia concessões importantes dos PDs, como a redução de todos os subsídios domésticos distorcivos e o aumento substancial, efetivo e mensurável do acesso a seus mercados para todos os produtos agrícolas, ao mesmo tempo em que reafirmava e ampliava exceções que beneficiavam os PEDs, com base no princípio do Tratamento Especial e Diferenciado.

Ambas as propostas, portanto, inseriam-se em estratégias essencialmente distributivas, e esse perfil estratégico foi mantido no decorrer da Conferência.

Com efeito, a primeira reação dos EUA às demandas do G20 teria sido, como relatado, de descrédito - Robert Zoellick, Representante para o Comércio dos EUA, inicialmente sequer estaria disposto a encontrá-los em uma reunião bilateral. Para Narlikar e Tussie (2004), a ameaça apresentada pelo G20 não foi tida como crível pelos EUA e pela UE porque essas delegações tinham a expectativa de que o G20 acabasse se dissolvendo, como costumava ocorrer com coalisões que adotavam táticas distributivas. EUA e UE teriam agido com o propósito deliberado de acelerar essa dissolução, com incentivos (da parte dos EUA) como a promessa de negociação de FTAs e de concessão de quotas tarifárias e a ameaça de retaliação por meio do atraso nos processos de integração regional.

O G20, por sua vez, não estaria preparado para fazer concessões, conforme posteriormente admitido por seus próprios representantes. 
Uma vez estabelecido o impasse, é possível que tanto EUA e UE (tradicionalmente os principais players nas negociações comercias multilaterais) como o G20 (que representava metade da população e $63 \%$ dos agricultores do mundo) tenham mantido e reforçado as táticas distributivas por acreditar que seu poder relativo os capacitava a, com isso, elevar seus ganhos.

Outra interpretação consistente com a abordagem teórica deste trabalho deriva da "Teoria dos Prospectos". É possível explicar a insistência dos EUA e da UE em adotar estratégias reivindicadoras de valor após a reação negativa do G20 à proposta conjunta pela percepção desses países de que aquela era uma situação de perda, o que os levou a adotar abordagens mais arriscadas, com a intenção de reverter a situação. Deborah Elms (2006, p. 52) explica:

Value creating strategies do not contain risky tactics. Hence, when negotiators find
themselves in a position of loss $(\ldots)$, they are prepared to reach for value claiming
strategies and tactics with greater risks. Such an approach had the potential for
generating significant gains. Recall that the most risky tactics are those with all-or-
nothing outcomes. If you "win" with a risky tactic, you can "win" overall and rapidly
reset the status quo in your favour.

Em última instância, no entanto, nem EUA, nem UE, nem os participantes do G20 obtiveram ganhos derivados da negociação. Independente da motivação, a insistência dos principais atores em adotar estratégias puramente distributivas em lugar de estratégias mistasdistributivas impediu que o impasse em Agricultura fosse superado, conforme previsto na segunda hipótese enunciada por Odell (2009).

Já as negociações sobre os "Temas de Cingapura" seguiram um caminho diferente. Houve, sem dúvida, uma oposição inicial entre os demandantes na matéria (em especial a UE), que pleiteavam o lançamento em Cancun das negociações nos referidos temas, e a Índia, que ao lado de outros PEDs insistia que dito lançamento exigiria o "consenso explícito" dos Membros da OMC, o que, a seu ver, não ocorreria em Cancun. As estratégias iniciais, portanto, foram essecialmente distributivas.

No entanto, no decorrer da Conferência houve demonstrações de flexibilidade dos dois lados. Mesmo antes do recuo no último dia da reunião, quando teria concordado em abandonar três dos quatro "Temas de Cingapura" desde que fosse acordado o início imediato das negociações em facilitação de comércio, a UE já havia indicado disposição para incoporar táticas integrativas à sua estratégia negociadora. Já na abertura da reunião, por exemplo, Pascal Lamy, na ocasião Comissário Europeu para o Comércio, afirmara estar disposto a "ouvir as preocupações dos demais Membros” na matéria (LAMY, 2003a). 
Igualmente, diversos Membros que inicialmente se opunham aos "Temas de Cingapura" haviam indicado, durante a Conferência, disposição para considerar o lançamento, se não de todos, de ao menos alguns (um ou dois) dos quatro temas, especialmente caso houvesse avanços em outras áreas. Outras delegações, em lugar de se oporem abertamente ao lançamento das negociações, haviam apenas demandado maior esclarecimento, além de solicitar atividades de cooperação relacionadas aos temas.

Assim, em um exercício contrafactual, é possível imaginar que, caso a reunião não tivesse sido abruptamente encerrada pelo Chair Derbez, as delegações seguiriam incorporando táticas integrativas às suas estratégias e aproximando as posições, tornando possível, ao final, um acordo na matéria ${ }^{79}$. Com efeito, a história das negociações em Conferências Ministeriais evidencia que os acordos costumam ser alcançados no último momento, sendo necessário, muitas vezes, adiar o final da reunião (como ocorreu em Doha e em Bali, por exemplo) para permitir os últimos acertos.

Dessa forma, assim como as negociações em Agricultura, as discussões sobre os "Temas de Cingapura" na Conferência de Cancun ocorreram de acordo com o previsto na segunda hipótese.

\subsubsection{Conferência Ministerial de Hong Kong}

Assim como em Cancun, Agricultura continuou sendo o tema mais controverso e mais relevante da Conferência de Hong Kong, mesmo que o "Pacote de Desenvolvimento" tenha ocupado espaço significativo e crescente na preparação para a Conferência.

Ainda antes da reunião, a UE tornou-se alvo de fortes críticas do G20, dos EUA, e do Grupo de Cairns após apresentar uma proposta com oferta de acesso a mercados para produtos agrícolas que era significativamente inferior ao que se esperava ${ }^{80}$. Além disso, já no início da reunião, a UE teria se posicionado contra a definição de uma data para o fim dos subsídios às exportações agrícolas.

\footnotetext{
${ }^{79}$ Isso não significa, naturalmente, que as diferenças nas demais matérias em discussão seriam superadas.

${ }^{80}$ Como visto, chegou-se a alegar que o entusiasmo da UE pelo "Pacote de Desenvolvimento" representava, na verdade, uma tentativa de afastar a censura pela recusa do bloco em cortar suas tarifas agrícolas.
} 
Por outro lado, no primeiro dia da Conferência, Robert Portman, então Representante para o Comércio dos EUA, defendeu um pacote equilibrado em Agricultura, e solicitou publicamente à UE que concordasse com uma fórmula que efetivamente garantisse melhoria substancial em acesso a mercados agrícolas. No mesmo dia, o chanceler Celso Amorim exigiu o fim ou, no mínimo, a redução drática de todos os subsídios distorcivos. De forma geral, como vismos, os negociadores seguiram com suas estratégias distributivas, e condicionaram eventuais concessões ao atendimento das demandas nos temas de seu interesse.

Antevendo o recurso às táticas reivindicadoras de valor, o DG Pascal Lamy abrira a Conferência incentivando a incorporação de táticas integrativas ao comportamento das

delegações. Ele solicitou aos Ministros que não se prendessem a posições tradicionais já conhecidas, mas buscassem compreender as razões dos demais e assumir riscos, incluindo políticos - era uma provável referência à pressão doméstica exercida sobre as delegações. Ao final, recordou que Hong Kong tinha o propósito de manter vivas as chances de um "final feliz" para a Rodada Doha (LAMY, 2005d, p.1)..

E de fato, após seis longos dias e cinco noites exaustivas, finalmente, na última noite, Mandelson e Amorim chegaram a um acordo de compromisso que permitiu superar o impasse. Após concessões das duas delegações, pactuou-se que 2013 seria a data-limite para os subsídios à exportação de produtos agrícolas, e que parte substancial desse tipo de apoio seria eliminada até o final da primeira metade do período. Robert Portman teria atuado como um mediador, ad hoc e informal, insistindo com Amorim que aceitasse o acordo.

Em suma, para evitar o fracasso em Hong Kong e manter a viabilidade da Rodada, G20, EUA e UE incorporaram táticas integrativas aos seus comportamentos, transformando suas estratégias distributivas em mistas-distributivas. Como resultado, o impasse em Agricultura foi superado, assim como previsto pela segunda hipótese.

\subsection{Terceira hipótese}

A terceira hipótese é a de que as chances de superar um impasse aumentam, em média, nas negociações em que há um mediador e em que se busca acordar um texto por consenso, na medida em que o mediador utiliza mais táticas inclusivas e propõe um texto negociador mais robusto, e vice-versa. (ODELL, 2009). A terceira hipótese seria desconfirmada caso fosse 
empiricamente demonstrado que mediadores que utilizam táticas menos inclusivas, mais cautelosas, ou evitam propor textos únicos de sua autoria associam-se a um número equivalente, ou maior, de acordos (ODELL, 2009).

\subsubsection{Conferência Ministerial de Cancun}

Como visto no capítulo anterior, o embaixador uruguaio Pérez del Castillo, então Chair do Conselho Geral da OMC, elaborou duas versões do draft de Declaração Ministerial durante a preparação para a Conferência Ministerial de Cancun. A primeira delas era um texto curto, de quatro páginas, divulgado sob responsabilidade do Chair - ou seja, não acordado entre os Membros. Como vimos, continha muitas lacunas, e, segundo Del Castillo, refletia os poucos resultados concretos, os prazos não atendidos e a grande divergência de posições entre os Membros.

A segunda versão do draft, elaborada pelo Chair do Conselho Geral em "cooperação estreita" com o Diretor-Geral (DG) Supachai Panitchpakdi, foi circulada a menos de duas semanas da Conferência. O texto continha seis páginas e incluía anexos que estabeleciam frameworks para a negociação em cada tema, mas não especificavam datas, prazos ou números específicos. Novamente, não era um texto acordado, e deixava de incorporar comentários e propostas ao primeiro draft apresentados pelos Membros. Seus autores afirmaram que o texto resultava de consultas "longas e intensivas", ao longo de muitas semanas (WTO, 2003c).

Como vimos, tanto o processo de elaboração do draft nas semanas que antecederam a Conferência quanto o seu resultado foram criticados por Membros da OMC e por organizações da sociedade civil. Entre outros, alegou-se que o processo foi pouco transparente, que a proposta era "desbalanceada" e que, ao se abandonar "the established procedure of using a bracketed text" (NARLIKAR, 2004, p. 424), o texto deixou de refletir adequadamente as posições das diversas delegações.

Já em Cancun, no quarto dia da Conferência, uma terceira versão do draft de Declaração Ministerial foi distribuída às delegações. O Chair da Conferência Luiz Ernesto Derbez ressalvou que buscou reunir os insights resultantes do trabalho dos facilitadores e das demais formas de consulta e, a partir deles, construir um pacote amplo que pudesse ser aceito por todos (WTO, 2003i). 
Mas em lugar de receber a aprovação dos Membros, mais uma vez o draft gerou grande descontentamento e divergência. Em Agricultura e nos "Temas de Cingapura", houve quem criticasse o texto por ser ambicioso demais, e quem considerasse que ele não ia longe o bastante. Em NAMA, o texto reproduziu a fórmula não-linear das versões anteriores, e foi novamente reprovado por um grupo de PEDs. No tema do Algodão, o texto não refletia nem a demanda de eliminação dos subsídios ao algodão, nem a do pagamento de compensação aos países africanos, o que levou um representante da indústria africana do algodão a declarar: "the WTO is against us" (BRIDGES, 2003f).

Como visto anteriormente, a terceira hipótese propõe que uma intervenção ousada do mediador teria mais chances de sucesso que a apresentação de um draft excessivamente cauteloso. Conforme Odell (2009), as partes negociadoras seriam incentivadas a aceitarem o draft e a fazerem concessões nos casos em que o mediador propusesse um texto negociador único, de sua autoria e sob sua responsabilidade, que não reproduzisse alternativas concorrentes dos negociadores, que considerasse as consultas confidenciais realizadas, que incluísse todos os temas necessários (mas excluísse aqueles excessivamente controversos) e garantisse a distribuição equilibrada dos ganhos. Por outro lado, a superação do impasse, conforme a terceira hipótese, seria favorecida pela percepção de que o mediador agiu de maneira inclusiva (ODELL, 2009).

O comportamento de Del Castillo e de Derbez corresponde, em alguma medida, ao sugerido por Odell (2009) na terceira hipótese. De fato, as três versões do draft foram divulgadas sob responsabilidade dos Chairs, sem a aprovação prévia dos Membros, e não reproduziam as diferentes propostas apresentadas pelas delegações para cada matéria; cobriam substancialmente o conjunto de temas relevantes à negociação; e foram elaboradas com base em consultas, incluindo os "confessionários", em que informações confidenciais das delegações foram transmitidas em confiança aos facilitadores e aos Chairs.

Por que, então, os drafts propostos pelos Chairs não resultaram na superação do impasse em Cancun? Algumas possíveis razões para isso podem ser extraídas da argumentação apresentada por Odell (2009) ${ }^{81}$. Em primeiro lugar, os drafts não eram equilibrados, e isso impediu que o conjunto dos Membros avaliasse que poderia se beneficiar com os compromissos neles contidos. Em segundo lugar, foram mantidos no texto temas excessivamente controversos,

\footnotetext{
${ }^{81}$ Vide a apresentação das hipóteses na segunda parte do primeiro capítulo.
} 
como a fórmula para a redução de tarifas de bens industriais, o lançamento de negociações nos “Temas de Cingapura" e o tratamento conferido aos subsídios à exportação de produtos agrícolas.

Finalmente, a despeito das declarações em sentido contrário por parte dos Chairs, o processo de elaboração dos textos não foi reconhecido pelos Membros como inclusivo. É provável que o caráter member-driven da $\mathrm{OMC}$, mencionado no primeiro capítulo, tenha contribuído para essa percepção. Embora não haja regras formalmente estabelecidas a esse respeito, espera-se que os textos negociadores sejam propostos pelos Membros, e não pelo Chair, a quem caberia apenas mediar as discussões. Ao apresentar um texto sob sua responsabilidade, Del Castillo afastava-se da prática corrente, conforme ressaltado por Narlikar (2005, p. 48):

The traditional GATT and WTO practice for drafting a text for a Ministerial Conference involved putting together a 'bracketed text', that is, a text in which all the contested proposals of different parties were put within square brackets and were negotiated at the ministerial conference.

Conquanto relativamente incomum, o recurso a um texto negociador de autoria do Chair havia sido bem-sucedido em Doha: o chamado "Harbinson draft" (que recebeu este nome em função de seu autor, o então Chair do Conselho Geral, Stuart Harbinson) serviu de base às negociações e, em última instância, à Declaração de Doha. Mesmo em Doha, no entanto, houve protestos por parte de PEDs, que questionaram a autoridade do Chair para propor o draft e repudiaram a desconsideração dos seus pontos de vista.

Em suma, embora os Chairs tenham proposto um texto negociador robusto e de sua autoria, o impasse nas negociações não foi superado. Entre outras razões, isso pode ser atribuído à falta de equilíbrio e à manutenção de temas demasiado controversos no draft, bem como à percepção, por parte das delegações, de que o processo não foi suficientemente inclusivo. A rejeição ao draft provavelmente foi acentuada pela expectativa de que os textos negociadores sejam elaborados pelos Membros, e não pelo Chair, em função do caráter member-driven da OMC.

Assim, das duas variáveis independentes que compõem a terceira hipótese de Odell (2009), apenas uma estava presente na Conferência de Cancun: a apresentação de um texto negociador robusto. A segunda variável independente, vale dizer, a percepção de que o processo tenha sido conduzido de maneira inclusiva pelo mediador, não foi observada. Como consequência, a aplicação da terceira hipótese à Conferência de Cancun não é capaz de confirmar, e nem de desconfirmar, a hipótese. 


\subsubsection{Conferência Ministerial de Hong Kong}

A duas semanas e meia do início da Conferência de Hong Kong, a então Chair do Conselho Geral da OMC, a nigeriana Amina Mohamed, e o DG Pascal Lamy divulgaram aos Membros da OMC a primeira versão do draft de Declaração Ministerial que seria discutido na Conferência. Após uma versão intermediária e amplo debate em Genebra, a terceira versão do draft foi aprovada pelo Conselho Geral. Em 7 de dezembro de 2005 essa versão foi encaminhado ao Secretário John Tsang, que seria o Chair da Conferência de Hong Kong, com a observação de que enquanto algumas partes do draft haviam sido consensuadas pelos Membros e outras contavam com alto grau de convergência, o documento também continha seções que refletiam diferenças entre as delegações.

O draft era compreensivo: continha 11 páginas, além de anexos que tratavam dos principais temas em negociação. O anexo sobre Facilitação de Comércio havia sido aprovado pelo grupo negociador em Genebra; os demais eram de responsabilidade dos respectivos Chairs (ou seja, não eram textos acordados pelos Membros). Além do draft e dos anexos, também foi enviada ao Chair Tsang uma lista de perguntas sobre as negociações de Agricultura e NAMA.

No geral, os textos eram bem menos ambiciosos que aqueles que haviam sido encaminhados para discussão em Cancun. Não havia a pretensão, como dois anos antes, de que fossem acordadas as "modalidades completas" das negociações em Agricultura e NAMA; previase tão somente que os Ministros acordassem as datas em que tais modalidades seriam concluídas. Além disso, o draft deixava lacunas para serem preenchidas com as datas em que se acordaria como proceder em relação a diversas propostas relacionadas ao Tratamento Especial e Diferenciado; e orientava os Membros a intensificar as negociações em Serviços, Propriedade Intelectual e Meio Ambiente (BRIDGES, 2005q).

Em suma, o draft originalmente preparado pela Chair do Conselho Geral e pelo DG Lamy, apesar de não reproduzir diferentes propostas e contar com anexos não consensuados entre os Membros, seguiu uma linha cautelosa. Questões mais polêmicas, para as quais se entendeu que não seria possível chegar a consenso durante a Conferência, foram excluídas do draft e incluídas na lista de perguntas, as quais deveriam tão-somente auxiliar as negociações, sem a previsão de transformarem-se, ainda em Hong Kong, em compromissos para os Membros. Ao optar por esse 
caminho, "Lamy did not attempt to 'split the differences' between Members' negotiating positions, as has been attempted in the past with mixed results" (BRIDGES, 2005q, p.1).

Assim que assumiu como DG, Lamy havia ressaltado o caráter member-driven da OMC, observando que as decisões não cabem ao DG, mero mediador, mas aos Membros. Além disso, cientes das críticas aos processos anteriores, o DG Lamy e o Chair Tsang esforçaram-se para assegurar em Hong Kong uma abordagem bottom-up. Embora as negociações tenham-se concentrado em reuniões do tipo Green Room, nas reuniões diárias de Chefes de Delegação todos os Membros eram informados das discussões e tinham a oportunidade de se manifestarem. Assim, "all Members were able to stay abreast of developments in the Ministerial Conference as they unfolded" (MANDUNA, 2006, p. 21). Houve também o cuidado de conceder aos Ministros mais tempo para analisar o draft na medida em que ele evoluía, embora esse tempo tenha-se reduzido nas fases finais da reunião (MANDUNA, 2006). Como resultado, quase não houve reclamações relacionadas à falta de abertra, transparência ou inclusão no processo negociador.

Em síntese, da mesma forma que em Cancun, verificou-se na Conferência de Hong Kong a presença de apenas uma, das duas variáveis independentes que compõem a terceira hipótese de Odell (2009). Enquanto a segunda variável independente - a percepção de utilização de táticas inclusivas por parte do mediador - estava presente, a primeira variável independente - a adoção de um texto negociador robusto - não foi observada. Assim, da mesma forma que na Conferência de Cancun, o comportamento dos mediadores na Conferência de Hong Kong não confirma, mas também não desconfirma, a terceira hipótese de Odell (2009).

\subsection{Conclusão do Capítulo 3}

A aplicação das três hipóteses elaboradas por Odell (2009) aos casos selecionados para este estudo revelou resultados heterogêneos. Enquanto as duas primeiras hipóteses foram confirmadas por ambas as Conferências Ministeriais, a aplicação da terceira hipótese gerou resultados inconclusivos tanto para a Conferência de Cancun quanto para a Conferência de Hong Kong.

O quadro a seguir resume os resultados encontrados. 
Quadro 2. Resultados da aplicação das hipóteses aos casos

\begin{tabular}{|c|c|c|c|}
\hline \multicolumn{2}{|c|}{ Hipóteses (ODELL, 2009) } & Conferência de Cancun & Conferência de Hong \\
\hline Primeira & $\begin{array}{l}\text { Se uma parte percebe que a } \\
\text { melhor alternativa ao acordo } \\
\text { (BATNA) piorou, o seu } \\
\text { negociador mudará a } \\
\text { estratégia no sentido de } \\
\text { reduzir as demandas, suavizar } \\
\text { as táticas distributivas e } \\
\text { acrescentar táticas } \\
\text { integrativas. Já a percepção } \\
\text { de melhora na BATNA } \\
\text { direcionará a estratégia para o } \\
\text { sentido contrário, em média, } \\
\text { e outras circunstâncias } \\
\text { mentidas constantes. }\end{array}$ & $\begin{array}{l}\text { Hipótese confirmada. } \\
\text { Na Conferência de Cancun a } \\
\text { BATNA era mais atraente } \\
\text { que na Conferência anterior } \\
\text { (realizada em Doha, dois anos } \\
\text { antes), o que elevou os pontos } \\
\text { de resistência dos } \\
\text { negociadores. Com menos } \\
\text { incentivos para fazerem } \\
\text { concessões em favor das } \\
\text { outras delegações, as táticas } \\
\text { distributivas foram mantidas } \\
\text { até o final da reunião }\end{array}$ & \begin{tabular}{l}
\multicolumn{3}{c}{ Hipótese confirmada. } \\
Já na Conferência de \\
Hong Kong ocorreu o \\
inverso. A BATNA era \\
menos atraente que em \\
Cancun, fazendo os \\
pontos de resistência \\
recuarem.
\end{tabular} \\
\hline Segunda & $\begin{array}{l}\text { As chances de superar um } \\
\text { impasse aumentam, em média } \\
\text { e sempre que as partes têm } \\
\text { um objetivo comum, na } \\
\text { medida em que as partes se } \\
\text { afastam de políticas } \\
\text { distributivas estritas e se } \\
\text { aproximam de estratégias } \\
\text { mistas-integrativas. }\end{array}$ & $\begin{array}{l}\text { Hipótese confirmada. } \\
\text { Na Conferência de Cancun a } \\
\text { manutenção de táticas } \\
\text { puramente distributivas pelos } \\
\text { principais atores impediu que } \\
\text { o impasse em Agricultura } \\
\text { fosse superado; já nas } \\
\text { discussões sobre os "Temas } \\
\text { de Cingapura" é possível } \\
\text { imaginar, em um exercício } \\
\text { contrafactual, que a } \\
\text { incorporação progressiva de } \\
\text { táticas integrativas, apenas } \\
\text { iniciada, teria tornado } \\
\text { possível um acordo na } \\
\text { matéria, caso a reunião não } \\
\text { tivesse sido abruptamente } \\
\text { encerrada } 83 \text {. }\end{array}$ & $\begin{array}{l}\text { Hipótese confirmada. } \\
\text { Ao longo da Conferência } \\
\text { de Hong Kong, os } \\
\text { principais atores } \\
\text { transformaram suas } \\
\text { estratégias distributivas } \\
\text { em mistas-distributivas e, } \\
\text { ao final, o impasse foi } \\
\text { superado. }\end{array}$ \\
\hline
\end{tabular}

\footnotetext{
${ }^{82}$ Excetuada, como visto, a flexibilidade demonstrada pela UE quanto aos "Temas de Cingapura".
} 


\begin{tabular}{|c|c|c|c|}
\hline Terceira & $\begin{array}{l}\text { As chances de superar um } \\
\text { impasse aumentam, em } \\
\text { média, nas negociações em } \\
\text { que há um mediador e em que } \\
\text { se busca acordar um texto por } \\
\text { consenso, na medida em que } \\
\text { o mediador utiliza mais } \\
\text { táticas inclusivas e propõe um } \\
\text { texto negociador mais } \\
\text { robusto, e vice-versa. }\end{array}$ & $\begin{array}{l}\text { Resultados inconclusivos. } \\
\text { Na Conferência de Cancun os } \\
\text { Chairs propuseram um draft } \\
\text { robusto, mas o processo } \\
\text { negociador não foi percebido } \\
\text { pelo conjunto das delegações } \\
\text { como inclusivo. A presença } \\
\text { de uma e a ausência de outra } \\
\text { das variáveis independentes } \\
\text { impossibilita que a aplicação } \\
\text { ao caso confirme ou } \\
\text { desconfirme a hipótese. }\end{array}$ & $\begin{array}{l}\text { Resultados inconclusivos. } \\
\text { Na Conferência de Hong } \\
\text { Kong o draft proposto } \\
\text { pelos mediadores era } \\
\text { modesto, mas o processo } \\
\text { negociador for } \\
\text { considerado inclusivo. } \\
\text { Mais uma vez, a presença } \\
\text { de apenas uma das } \\
\text { variáveis independentes } \\
\text { impossibilitarara seja } \\
\text { confirmar seja } \\
\text { desconfirmar a hipótese. }\end{array}$ \\
\hline
\end{tabular}




\section{Considerações finais}

No primeiro capítulo deste trabalho, foram apresentadas as abordagens tradicionais da Economia Política Internacional (EPI), as quais, ao abordar as questões centrais da disciplina, destacam variáveis relacionadas ao poder, às instituições, às ideias ou à dimensão doméstica. Concluiu-se que, conquanto certamente auxiliem na compreensão das causas dos impasses nas negociações da Rodada Doha, os fatores destacados por essas tradições não explicam os diferentes resultados alcançados pela Quinta Conferência Ministerial da OMC, realizada em Cancun, em 2003, que terminou em impasse, e pela Sexta Conferência Ministerial, realizada em Hong Kong, em 2005, que resultou na adoção de uma Declaração Ministerial.

De fato, a despeito da ascensão relativa de China, Índia e Brasil nas últimas décadas, a distribuição de capabilities entre os Estados não foi substantivamente alterada entre 2003 e 2005; e, de todo modo, o enfraquecimento gradual do poder hegemônico norte-americano durante as últimas décadas sugeriria que o impasse ao final da Conferência de Cancun se mantivesse, ou se agravasse, dois anos depois, na Conferência de Hong Kong - o que, como se sabe, não ocorreu.

Da mesma forma, as características institucionais que constrangiam as negociações da Conferência de Cancun, como a regra do consenso e o single undertaking, não foram alteradas na Conferência de Hong Kong. Tampouco houve, no curto intervalo entre as duas Conferências, transformações ideacionais que justificassem os diferentes resultados. Finalmente, entre 2003 e 2005 não foram observadas rupturas significativa na dinâmica doméstica dos principais players em relação às negociações multilaterais de comércio, nem outros fatores domésticos a que se pudesse atribuir o impasse em Cancun e o consenso em Hong Kong.

Em contraste, a teoria de médio alcance proposta por John Odell (2000, 2006, 2009), também introduzida no primeiro capítulo, demonstrou ser capaz de explicar os resultados distintos das duas Conferências Ministeriais. Ao ressaltar o comportamento das delegações e dos mediadores durante as negociações, tanto no processo preparatório quanto durante as duas Conferências, a abordagem permitiu identificar as diferentes estratégias adotadas em cada ocasião, bem como associá-las aos diferentes resultados encontrados.

Para possibilitar a identificação desses comportamentos, no segundo capítulo as Conferências de Cancun e de Hong Kong foram contextualizadas e reconstruídas de forma minuciosa. Para cada Conferência foram abordados, entre outros, as principais questões em discussão; a posição substantiva dos principais atores; o processo de preparação; o 
desenvolvimento das negociações (o "dia-a-dia" da reunião); e os resultados alcançados, incluindo a repercução do evento.

No terceiro capítulo as três hipóteses desenvolvidas por John Odell em 2009 foram "testadas" por meio de sua aplicação aos casos selecionados. Ao final, como visto, duas das três hipóteses foram confirmadas e uma delas gerou resultados inconclusivos.

A primeira hipótese, que associa alterações na BATNA - melhor alternativa ao acordo - a mudanças nas estratégias adotadas pelos negociadores, foi confirmada tanto pela Conferência de Cancun quanto pela Conferência de Hong Kong.

Com efeito, na Conferência de Cancun o sucesso no lançamento de uma nova rodada de negociações, dois anos antes, e a nova fase na luta contra o terrorismo, já com o envolvimento efetivo de instituições internacionais como a OTAN e o Conselho de Segurança da ONU, haviam tornado a BATNA mais atraente quando comparada àquela da Conferência Ministerial anterior. Os pontos de resistência dos negociadores elevaram-se; com menos incentivos para fazerem concessões em favor das outras delegações, as táticas distributivas foram mantidas pelos negociadores até o final da reunião. Assim, a primeira hipótese foi confirmada.

Em sentido inverso, na Conferência de Hong Kong a BATNA tornara-se novamente pouco atraente: eventual fracasso seria o segundo consecutivo nas negociações da Rodada Doha, e poderia ter efeitos devastadores para as negociações comerciais multilaterais; esse risco era acentuado pelo fim iminente, em meados de 2007, da Trade Promotion Authority concedida pelo Congresso dos EUA ao Presidente Bush. Os pontos de resistência recuaram; os negociadores reduziram suas demandas, suavizaram táticas distributivas e incorporaram táticas integrativas, mais uma vez confirmando a primeira hipótese.

A segunda hipótese, que associa a adoção de estratégias mistas-integrativas por parte dos negociadores à superação de impasses, também foi confirmada pelas duas Conferências Ministeriais.

De fato, na Conferência de Cancun a manutenção de táticas puramente distributivas pelos principais atores, com a insistência de EUA, UE e G20 em manter suas posições iniciais, impediu que o impasse em Agricultura fosse superado; já nas discussões sobre os "Temas de Cingapura" eventual incorporação progressiva de táticas integrativas, apenas iniciada pela UE (que nos momentos finais aceitou lançar negociações de somente um dentre os quatro temas), poderia ter 
tornado possível um acordo na matéria caso a reunião não tivesse sido abruptamente encerrada ${ }^{84}$. As duas observações confirmaram a segunda hipótese.

Já ao longo da Conferência de Hong Kong os principais atores abandonaram as estratégias puramente distributivas, transformando-as em mistas-distributivas: de fato, na última noite da reunião, UE e G20, com a mediação dos EUA, aceitaram um acordo de compromisso sobre o fim dos subsídios às exportações agrícolas. Novamente, a segunda hipótese foi confirmada.

Por fim, a terceira hipótese associa o comportamento do mediador (proposição de texto negociador robusto e utilização de táticas inclusivas) à superação de impasses. Diferentemente das hipóteses anteriores, a aplicação da terceira hipótese aos casos gerou resultados inconclusivos: ela não foi confirmada, nem desconfirmada, por nenhuma das duas Conferências Ministeriais.

Realmente, na Conferência de Cancun os Chairs propuseram um draft robusto, mas o processo negociador não foi percebido pelo conjunto das delegações como inclusivo, e a reunião terminou em impasse. Na Conferência de Hong Kong ocorreu o inverso: o draft proposto pelos mediadores era modesto, mas o processo negociador foi considerado inclusivo, e o impasse foi superado ao final da reunião. Como em nenhuma das Conferências Ministeriais as duas variáveis independentes previstas na terceira hipótese estavam simultaneamente presentes, não foi possível confirmar, nem desconfirmar a hipótese formulada por Odell.

No entanto, quando analisamos separadamente cada uma das variáveis independentes que compõem a hipótese, os casos sugerem uma correlação positiva entre a adoção de táticas inclusivas por parte dos mediadores e a superação dos impasses; em contraste, indicam uma correlação negativa entre a proposição de um texto negociador robusto e a superação dos impasses.

Como mencionado no capítulo anterior, é possível que essas correlações reflitam o caráter member-driven da OMC. Em estudos futuros, esse aspecto poderá ser investigado em maior profundidade, mediante a sua aplicação a outros casos, seja no âmbito da OMC, seja em outros fóruns de negociações econômicas internacionais. O resultado dessas novas investigações poderá resultar em um refinamento da hipótese e, por consequência, da teoria de médio alcance proposta por Odell (2000, 2006, 2009).

\footnotetext{
${ }^{84}$ Trata-se, como ressaltado anteriormente, de um exercício contrafactual, que não pressupõe que o dissenso nas demais matérias também seria superado.
} 
Em que pesem os resultados inconclusivos da aplicação da terceira hipótese, é possível concluir com segurança que os aspectos processuais contribuíram para os resultados alcançados nas duas Conferências Ministeriais. Alterações nas alternativas ao acordo em Cancun e em Hong Kong levaram a que os negociadores adotassem, nas duas Conferências, estratégias de negociação opostas, que, por sua vez, conduziram a resultados contrastantes - enquanto em 2003 as delegações insistiram em estratégias estritamente distributivas e a reunião terminou em impasse, em 2005 foram incorporadas táticas integrativas, e o impasse foi superado.

Pode-se afirmar, portanto, que os resultados das Conferências Ministeriais sob análise não foram inteiramente definidos por aspectos estruturais, como o poder, as instituições, as ideias e a dimensão doméstica; tais resultados decorreram também, e de forma destacada, do comportamento assumido pelos negociadores e pelos mediadores no decorrer do processo negociador.

Assim, se realmente as teorias tradicionais da EPI apresentam-se como capazes de explicar, de forma ampla, as dificuldades enfrentadas pelos Membros da OMC nas negociações da Rodada Doha (tal como detalhado na parte inicial do primeiro capítulo deste estudo), apenas um olhar direcionado ao processo das negociações, focado no comportamento dos atores, possibilitou compreender as razões dos recuos e avanços conjunturais observados por ocasião das duas Conferëncias Ministeriais em apreço.

Conclui-se, portanto, que os aspectos ressaltados, por um lado, pelas perspectivas tradicionais da EPI e, por outro lado, pela teoria sobre as negociações econômicas internacionais - elementos estruturais e processuais, dimensões macro e micro - são complementares para a compreensão das causas do impasse na Rodada Doha da Organização Mundial do Comércio (OMC). Nas palavras de Odell (2009, p. 295): “Outcomes are not determined completely by structure; they also vary with process." 


\section{Bibliografia}

AFRICAN GROWTH AND OPPORTUNITY ACT (AGOA). About AGOA. [s.d.]. Disponível em: <http://agoa.info/about-agoa.html>. Acesso em: 25 jan 2015

ALEXANDRAKI, K. Preference Erosion: Cause for Alarm?. Finance \& Development, mar. 2005. Disponível em: <https://www.imf.org/external/pubs/ft/fandd/2005/03/pdf/alexandr.pdf>. Acesso em: 25 jan 2015

AMORIM, C. Declaración del Excmo. Sr. Celso Amorim - Ministro de Relaciones Exteriores. WTO, 11 set. 2003. Disponível em: <https://www.wto.org/spanish/thewto_s/minist_s/min03_s/statements_s/st28.do>. Acesso em: 25 jan 2015

Discurso do Ministro das Relações Exteriores, Embaixador Celso Amorim, na Sexta Conferência Ministerial da OMC - Hong Kong, China, 14/12/2005. Resenha de Política Exterior do Brasil. Número 97, $2^{\circ}$ semestre de 2005, p. 211-212.

ANDERSSON, E. Who needs effective Doha negotiations, and why? International Negotiation, v. 17, pp. 189-209, 2012.

AZEVÊDO, R. DG Azevêdo's address to the MC10 closing ceremony. WTO, 19 dez. 2015. Disponível em: <https://www.wto.org/english/news_e/spra_e/spra108_e.htm>. Acesso em: 25 jan 2015

BALDWIN, R. Political Economy of the Disappointing Doha Round of Trade Negotiations. Pacific Rim Review, v. 12, n. 3, pp. 253-266, 2007.

BARACUHY, B. The Geopolitics of Multilateralism: The WTO Doha Rouns Deadlock, the BRICS, and the Challenges of Institutionalized Power Transitions. Working Paper $\mathrm{n}^{\circ} 4$, Centre for Rising Powers, Department of Politics and International Studies, University of Cambridge. Cambridge, 2012.

BARTON, J. H. et al. The evolution of the trade regime: politics, law and economics of the GATT and the WTO. Princeton, NJ: Princeton University Press, 2006.

BBC. Disponível em:

<http://www.bbc.com/portuguese/especial/1635_omc_quemequem/page5.shtml>. Acesso em: 25 jan 2015

BENDOR, J. Bounded Rationality and Politics. Preface. University of California Press, 2010.

BHAGWATI, J, A blend of strong measures puts trade talks back together, Financial Times, 20 dez. 2005. Disponível em: <http://www.ft.com/intl/cms/s/0/17171e90-70fe-11da-89d30000779e2340.html\#axzz3xkCxnudo>. Acesso em: 25 jan 2015 
BLUSTEIN, P. Misadventures of the Most Favored Nations: Clashing Egos, Inflated Ambitions, and the Great Shambles of the World Trade System. PublicAffairs, 2009.

BRECHER, M. International studies in the twentieth century and beyond: flawed dichotomies, synthesis, cumulation: ISA Presidential Address. International Studies Quarterly, v. 42, n. 2, pp. 213-264, jun. 1999.

BRIDGES. Discussions Wrap Up In Geneva; Remaining Rifts Left For Cancun. 28 ago. $2003 a$. Disponível em: <http://www.ictsd.org/bridges-news/bridges/news/discussions-wrap-up-ingeneva-remaining-rifts-left-for-cancun>.

Cancun Ministerial: Setting the Stag. 10 set. 2003b. Disponível em:

$<$ http://www.ictsd.org/bridges-news/bridges/news/bridges-daily-update-1-cancun-ministerialsetting-the-stage >.

Cotton - The 'Trips and Health' of Cancun?. 11 set. 2003c. Disponível em:

$<$ http://www.ictsd.org/bridges-news/bridges/news/bridges-daily-update-2-cotton-the-trips-andhealth-of-cancun>.

Will Chair's AG Text Warm Up Frozen Talks?. 12 set. 2003d. Disponível em:

<http://www.ictsd.org/sites/default/files/news/bridges-daily-update-3_2.pdf>. Acesso em: 25 jan 2015

. New Ministerial Text to be Issued Today. 13 set. 2003e. Disponível em:

<http://www.ictsd.org/sites/default/files/news/bridges-daily-update-4_2.pdf>. Acesso em: 25 jan 2015

At the Eleventh Hour, Divergence All Over Again. 14 set. 2003f. Disponível em:

<http://www.ictsd.org/sites/default/files/news/bridges-daily-update-5_1.pdf>. Acesso em: 25 jan 2015

em:

. Cancun Collapse: Where There's No Will There's No Way. 15 set. 2003g. Disponível

<http://www.ictsd.org/sites/default/files/news/bridges-daily-update-6.pdf>. Acesso em: 25 jan 2015

WTO Members Aim For July 'Approximations, ' Hong Kong Deal. 16 fev. $2005 a$.

Disponível em: <http://www.ictsd.org/bridges-news/bridges/news/wto-members-aim-for-julyapproximations-hong-kong-deal>. Acesso em: 25 jan 2015 
Trade Community Searches for Way Forward in Doha Talks as Lamy Takes Helm. 7 set. 2005b. Disponível em:<http://www.ictsd.org/bridges-news/bridges/news/trade-communitysearches-for-way-forward-in-doha-talks-as-lamy-takes-helm>. Acesso em: 25 jan 2015

Ag: FIPs Ministers' Meet Ends Abruptly; EU To Make New Offer On Market Access?. 26 out. 2005c. Disponível em: <http://www.ictsd.org/bridges-news/bridges/news/ag-fipsministers-meet-ends-abruptly-eu-to-make-new-offer-on-market-access>. Acesso em: 25 jan 2015

EU Offer Of Deeper Farm Tariff Cuts Fails To Restart Talks. 2 nov. 2005d. Disponível em: <http://www.ictsd.org/bridges-news/bridges/news/eu-offer-of-deeper-farm-tariff-cuts-failsto-restart-talks $>$. Acesso em: 25 jan 2015

Members 'recalibrating' expectations for Hong Kong and beyond. 16 nov. 2005e. Disponível em: <http://www.ictsd.org/bridges-news/bridges/news/members-recalibratingexpectations-for-hong-kong-and-beyond>. Acesso em: 25 jan 2015

Five Ministers Aiming For Doha Round Road Map In Hong Kong. 23 nov. $2005 f$. Disponível em: <http://www.ictsd.org/bridges-news/bridges/news/five-ministers-aiming-fordoha-round-road-map-in-hong-kong>. Acesso em: 25 jan 2015

. Ministerial Chair John Tsang: Development Package Must Not Be "Bargaining Chip". 7 dez. 2005g. Disponível em: <http://www.ictsd.org/bridges-news/bridges/news/ministerial-chairjohn-tsang-development-package-must-not-be-bargaining>. Acesso em: 25 jan 2015

Members Scale Back Expectations For Hong Kong. 9 nov. 2005h. Disponível em: <http://www.ictsd.org/bridges-news/bridges/news/members-scale-back-expectations-for-hongkong>. Acesso em: 25 jan 2015

WTO members endorse draft Hong Kong text after spat over services. 7 dez. $2005 \mathrm{i}$.

Disponível em: <http://www.ictsd.org/bridges-news/bridges/news/wto-members-endorse-drafthong-kong-text-after-spat-over-services>. Acesso em: 25 jan 2015

. Expectations Low as Hong Kong Ministerial Gets Underway. 13 dez. 2005j. Disponível em: <http://www.ictsd.org/bridges-news/bridges/news/bridges-daily-update-1-expectations-lowas-hong-kong-ministerial-gets $>$.

. Ministerial Chair John Tsang Announces Facilitators For Hong Kong Summit. 7 dez. 2005k. Disponível em: <http://www.ictsd.org/bridges-news/bridges/news/ministerial-chair-johntsang-announces-facilitators-for-hong-kong-summit>. Acesso em: 25 jan 2015

Brinkmanship Marks First Day’s Proceedings. 14 dez 20051. Disponível em:

<http://www.ictsd.org/bridges-news/bridges/news/bridges-daily-update-2-brinkmanship-marksfirst-day\%E2\%80\%99s-proceedings > . Acesso em: 25 jan 2015 
Will Members Reveal Their Cards in Time? 15 dez. 2005m. Disponível em: <http://www.ictsd.org/sites/default/files/news/bridges-daily-update-3-en051215.pdf>. Acesso em: 25 jan 2015

New Text in the Works. 16 dez. 2005n. Disponível em:

<http://www.ictsd.org/bridges-news/bridges/news/bridges-daily-update-4-new-text-in-the-work>. Acesso em: 25 jan 2015

Revised Ministerial Draft to be Issued Today. 17 dez. 2005o. Disponível em:

<http://www.ictsd.org/bridges-news/bridges/news/bridges-daily-update-5-revised-ministerialdraft-to-be-issued-today>. Acesso em: 25 jan 2015

Talks Continue Around the Clock in Search of Consensus. 18 dez. 2005p. Disponível em: <http://www.ictsd.org/bridges-news/bridges/news/bridges-daily-update-6-talks-continuearound-the-clock-in-search-of $>$. Acesso em: 25 jan 2015

Members Discuss Lamy's Draft Ministerial Text; Revisions To Follow. 30 nov. 2005q. Disponível em:

<http://www.ictsd.org/bridges-news/bridges/news/members-discuss-lamys-draft-ministerial-textrevisions-to-follow $>$. Acesso em: 25 jan 2015

WTO Ministerial Conference Opens in Geneva: Expect No Surprises. 30 nov. 2009. Disponível em: <http://www.ictsd.org/sites/default/files/news/bridges-daily-update-1_0.pdf> WTO: Mixed Expectations as Delegations Arrive for Eighth Ministerial Conference. 14 dez. 2011. Disponível em:

$<$ http://www.ictsd.org/bridges-news/bridges/news/wto-mixed-expectations-as-delegations-arrivefor-eighth-ministerial>. Acesso em: 25 jan 2015.

. OVERVIEW OF OUTCOMES OF WTO'S 10TH MINISTERIAL IN NAIROBI. 19 DEZ. 2015. DISPONÍVEL EM:

<http://www.ictsd.org/sites/default/files/bridges-daily-update-5-nairobi-final2.pdf>. Acesso em: 25 jan 2015

CARIBBEAN COMMUNITY (CARICOM). History of the Caribbean Community. 2011.

Disponível em: <http://www.caricom.org/jsp/community/history.jsp?menu=community>. Acesso em: 25 jan 2015

CARVALHO, M. I. V. Condicionantes internacionais e domésticos: O Brasil e o G-20 nas negociações agrícolas da Rodada Doha. Dados, v.53, n.2, 2010. 
CHO, S. A Bridge Too Far: The Fall of the Fifth WTO Ministerial Conference in Cancún and the Future of Trade Constitution. Journal of International Economic Law, v. 7, n. 2, p. 219-244, 2004.

CNN. WTO nears deal amid protests. 18 dez. 2005. Disponível em: <http://edition.cnn.com/2005/BUSINESS/12/17/wto.protests/>. Acesso em: 25 jan 2015

COSMIDES, L.; TOOBY, J. Better than Rational: Evolutionary Psychology and the Invisible Hand. The American Economic Review, v.84, n.2, p. 327-332, mai. 1994.

DAVIS, C. Cashing in on Cooperation. Harvard International Review, 01 fev. 2010. Disponível em: <http://hir.harvard.edu/big-ideascashing-in-on-cooperation/>. Acesso em: 25 jan 2015

DEL CASTILLO, C. P. Statement by H.E. Mr. Pérez Del Castillo Chairman of the General Council. WTO, 10 set. 2003. Disponível em:

<https://www.wto.org/english/thewto_e/minist_e/min03_e/statements_e/11.doc>.

DEL CASTILLO, C. P.; PANITCHPAKDI, S. Cover letter of the draft Cancún Ministerial Text. WTO, 21 ago. 2003. Disponível em:

<https://www.wto.org/english/thewto_e/minist_e/min03_e/draft_decl_covletter_e.htm>. Acesso em: 25 jan 2015

DELGADO, N. S.; SOARES, A. C. O.; The G-20: Its Origin, Evolution, Meaning and Prospects. Global Issue Papers, n.25, dez. 2005. Disponível em:

<https://www.boell.de/sites/default/files/assets/boell.de/images/download_de/internationalepoliti k/GIP_25_Engl_G-20.pdf>. Acesso em: 25 jan 2015

DERBEZ, L. E. Address by H.E. Dr. Luis Ernesto Derbez Secretary Of Foreign Affairs, Mexico, and Chairman of the Fifth Session. WTO, 10 set. 2003. Disponível em:

<https://www.wto.org/english/thewto_e/minist_e/min03_e/statements_e/9.pdf>.Acesso em

DUPONT, C. Review: Negotiating the World Economy, by John Odell. World Trade Review. v. 1, n. 1, p. 115-120, 2002.

:

EIZENSTAT, S.; ROBERTS, C. The WTO after Hong Kong: how a deal can be struck in 2006. International Economics and Economy Policy, v. 3, n.1, p. 1-6, 2006.

ELMS, D. New directions for Ipe: drawing from behavioral economics. International Studies Review, v. 10, n. 2, pp. 239-265, jun. 2008.

. How bargaining alters outcomes: bilateral trade negotiations and bargaining strategies. International Negotiation, v. 11, n. 3, 2006, p. 399-429.

EUROPEAN COMISSION. NAMA: what is a Swiss Formula?. Dez. 2005. Disponível em: <http://trade.ec.europa.eu/doclib/docs/2005/december/tradoc_126417.pdf>. Acesso em: 25 jan 2015 
Everything But Arms (EBA) - Who benefits? 10 out. 2014. Disponível em:

<http://trade.ec.europa.eu/doclib/docs/2014/october/tradoc_152839.pdf>. Acesso em: 25 jan 2015

EVENETT, S. The Doha Round Impasse: a graphical account. Review of International Organizations, v. 9, n. 2, p. 143-162, 2014.

."Global Europe": an initial assessment of the European Comission's new trade policy. The Swiss Review of International Economic Relations, 2006.

. The Failure of the WTO Ministerial Meeting in Cancun: Implications for Future Research. CESifo Forum - ifo Institute for Economic Research, Munique, v. 4, n. 3, p. 11 - 17, 2003. Disponível em: <http://www.cesifogroup.de/ifoHome/publications/docbase/details.html?docId=14562682>. Acesso em 02 jul. 2014.

FINANCIAL TIMES. Bali breathes life into global trade. 08 dez. 2013. Disponível em: <http://www.ft.com/intl/cms/s/0/69a7c63e-5e83-11e3-a44c00144feabdc0.html\#axzz36KsojpNt>. Acesso em: 02 jul. 2014.

GOLDSTEIN, J.; KEOHANE, R. O. Ideas and Foreign Policy: Beliefs, Institutions and Political Change. Nova Iorque: Cornell University Press, 1993.

GUZZINI, Stefano. Realism in International Relations and International Political Economy: the continuing story of a death foretold. New York: Ruthledge, 2002.

HARDIN, G. The Tragedy of the Commons. Science, v. 162, n. 3852, p. 1243 - 1248. Disponível em: <http://science.sciencemag.org/content/162/3859/1243>. Acesso em: 25 jan 2015

HOEKMAN, B. M.; MAVROIDIS, P. C. WTO 'à la carte' or WTO 'menu du jour'? Assessing the case for plurilateral agreements. San Domenico di Fiesole, European University Institute, 2013 (Global Governance Programme-57). Disponível em:

<http://globalgovernanceprogramme.eui.eu/wpcontent/uploads/2012/11/Hoekman_Mavroidis_Plurilaterals.pdf>. Acesso em: 06 jul. 2013.

HOMEKU, T. Still in the dark on the road to Cancun. TWN, 2003. Disponível em: <http://www.twn.my/title/twe310b.htm>. Acesso em: 25 jan 2015

HUFBAUER, G. C.; SCHOTT J. J. Will the World Trade Organization Enjoy a Bright Future? Washington, DC: Petersen Institute for International Economics, 2011 (Policy Brief 12-11). Disponível em: <http://www.piie.com/publications/pb/pb12-11.pdf>. Acesso em: 06 jul. 2013.

JAITLEY, A. Statement by H.E. Mr Arun Jaitley - Minister of Commerce and Industry and Law and Justice. WTO, 10 set. 2003. Disponível em: 
<https://www.wto.org/english/thewto_e/minist_e/min03_e/statements_e/st7.pdf>. Acesso em: 25 jan 2015

JONES, B. Routhledge Encyclopedia of International Political Economy. Routhledge, 2001.

JONQUIERES, G. Shock Therapy. The world today, v. 64, n. 5, pp. 25-27, mai 2008.

KAHLER, M. Rationality in International Relations. International Organization, v. 52, n. 4, International Organization at Fifty: Exploration and Contestation in the Studies of World Politics, pp. 919-941, 1998.

KEOHANE, R. Rational choice theory and international law: insights and limitations. The Journal of Legal Studies, v. 31, n. S1, pp. S307-S319, jan. 2002.

International institutions: can interdependence work? Foreign Policy, n. 110, Special Edition: Frontiers of Knowledge, pp. 82-96+194, 1998.

After hegemony: transatlantic economic relations in the next decade. The International Spectator: Italian Journal of International Affairs. v. 19, n. 1, 1984, p. 3-9.

KEOHANE, R; GOLDSTEIN, Judith. Ideas and Foreign Policy: Beliefs, Institutions and Political Change. Ithaca, NY: Cornell University Press, 1993.

KING, G.; KEOHANE, R. e VERBA, S.. Designing Social Inquiry: Scientific Inference in Qualitative Research. Princeton: Princeton University Press, 1994.

KRASNER, S. Structural Causes and Regime Consequences: Regimes as Intervening Variables. International Organization. V. 36, n. 2, p. 185-205, 1982.

LAMY, P. Can the Doha Development Agenda live up to his name? 10 set. 2003a. Disponível em: 〈http://europa.eu/rapid/press-release_SPEECH-03-399_en.pdf〉. Acesso em: 25 jan 2015

. Press Conference closing the World Trade Organisation $5^{\text {th }}$ Ministerial Conference. 14 set 2003b. Disponível em: <http://trade.ec.europa.eu/doclib/html/113765.htm〉. Acesso em: 25 jan 2015

The Doha Development Agenda isback on track. 31 jul. 2004. Disponível em: <http://euun.europa.eu/articles/en/article_3723_en.htm>. Acesso em: 25 jan 2015

. Lamy lauds China's contribution to world economy. WTO, 15 set. 2005a. Disponível em: <https://www.wto.org/english/news_e/sppl_e/sppl01_e.htm>. Acesso em: 25 jan 2015

. Pascal Lamy's Ministerial Conference Diary. WTO, 2005b. Disponível em:

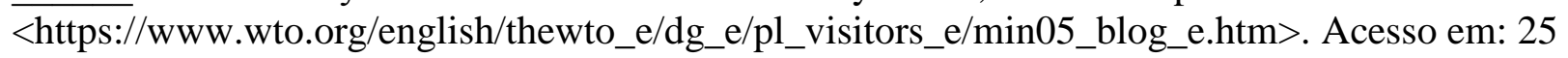
jan 2015

DG diary Monday 12 Dec. 12 dez. 2005c. Disponível em: 
<http://engagedforums.com/discussions/WTO_forum/Discussions/DG_diary_Monday_12_Dec/ wtoforum/2109? redirCnt=1\&nav=messages $>$. Acesso em: 25 jan 2015

Open Ceremony. WTO, 13 dez. 2005d. Disponível em:

<https://www.wto.org/english/news_e/sppl_e/sppl15_e.htm>. Acesso em: 25 jan 2015

LANG, A. T. F. Reconstructing Embedded Liberalism: John Gerard Ruggie and Constructivist Approaches to the Study of the International Trade Regime. Journal of International Economic Law, v.9, n,1, p. 81-116, mar. 2006.

LAWRENCE, R. E. Rulemaking amidst growing diversity: a club-of-clubs approach to WTO reform and new issue selection. Journal of International Economic Law, v. 9, n. 4, p. 823-835, 2006.

LAX, D; SEBENIUS, J. Negotiating through an agent. The Journal of Conflict Resolution, v. 35 , n.3 p. 474-493, 1991.

LEE, D.; WILKINSON, R. (Orgs.). The WTO after Hong Kong: Progress in, and prospects for, the Doha Development. Routhledge, 2007.

LIM, Timothy. Doing Comparative Politics: An Introduction to Approaches and Issues. 2a edição. Boulder: Lynne Rienner Publishers, 2010.

LIJPHART, Arend. Comparative Politics and the Comparative Method. The American Political Science Review, v. 65, n. 3, p. 682-693.

MANDELSON, P. Speech by EU Commissioner Mandelson on keeping the Doha Round moving. 2005. Disponível em: <http://eu-un.europa.eu/articles/en/article_5472_en.htm>. Acesso em: 25 jan 2015

MANDUNA, C. A review of the results of the 6th WTO Hong Kong Ministerial Conferenceconsiderations for African, Caribbean and Pacific countries. Trade Law Center for Southern Africa. Working Paper No 6/2006, jun. 2006. Disponível em: <http://paulroos.co.za/wpcontent/blogs.dir/12/files/2011/uploads/20060620_Hong_Kong_review_Manduna.pdf $>$. Acesso em: 11 jan 2016.

MAVROIDIS, P. G. Trade in Goods: The GATT and the Other WTO Agreements Regulating Trade in Goods. Oxford: Oxford University Press, 2012.

MCKIBBEN, H. The effects of structures and power on state bargaining strategies. American Journal of Political Science, v. 37, n 2, 2013, p. 411-427.

MILES, T. Nine reasons why India's WTO veto shocked the world. Reuters, 1 ago. 2014. Disponível em: <http://in.reuters.com/article/2014/08/01/india-trade-wto-reasonsidINKBN0G13HY20140801>. Acesso em: 15 nov 2014. 
MILNER, H. V. International Political Economy: Beyond Hegemonic Stability. Foreign Policy, n 110, 1998, p. 112-123.

MILNER, H. V.; ROSENDORFF, B.P. Democratic Politics and International Trade Negotiations: Elections and Divided Government As Constraints on Trade Liberalization. Journal of Conflict Resolution, v. 41, n. 1, p. 117 - 149, fev. 1997.

MUZAKA, V.; BISHOP, M. L. Doha stalemate: the end of trade multilateralism? Review of International Studies, v. 41, n. 2, pp. 383-406, abr. 2015.

.The Optimal Design of International Trade Institutions: Uncertainty and Escape. International Organization, v.55, n.4, 2001, p. 829-857.

NARLIKAR, A. The ministerial process and power dynamics in the World Trade Organization: understanding failure from Seattle to Cancun. New Political Economy. v. 9, n..3, p. 413-428, 2004.

2005

The World Trade Organization: A Very Short Introduction. Oxford University Press,

. New powers in the club: the challenges of global trade governance. International Affairs. v. 86, n. 3 , p. $717-728,2010$.

NARLIKAR, A.; WILKINSON, R. Collapse at the WTO: A Cancun Post-Morten. Third World Quarterly, v. 25, n. 3, p. 447-460, 2004.

NARLIKAR, A.; TUSSIE, D. The G20 at the Cancun Ministerial: Developing Countries and Their Evolving Coalitions in the WTO. 2004. Disponível em:

<http://www.dianatussie.com.ar/downloads/The\%20G20\%20at\%20the\%20Cancun\%20Ministeri al\%20Developing \%20Countries\%20and\%20their\%20Evolving\%20Coalitions\%20in\%20the\%20 WTO.pdf>. Acesso em: 25 jan 2015

ORGANIZAÇÃO DAS NAÇÕES UNIDAS (ONU). Resolution 1373. 28 set. 2001a. Disponível em:

<http://www.un.org/en/sc/ctc/specialmeetings/2012/docs/United\%20Nations\%20Security\%20Co uncil\%20Resolution\%201373\%20(2001).pdf>. Acesso em: 25 jan 2015

Resolution 1386. 20 dez. 2001b. Disponível em: <http://daccess-ddsny.un.org/doc/UNDOC/GEN/N01/708/55/PDF/N0170855.pdf?OpenElement>. Acesso em: 25 jan 2015

Agreement on Provisional Arrangements in Afghanistan Pending the Re-

Establishment of Permanent Government Institutions. 5 dez. 2001c. Disponível em:

<http://www.un.org/News/dh/latest/afghan/afghan-agree.htm>. Acesso em: 25 jan 2015

ODELL, J. Negotiating the World Economy. Ithaca: Cornell University Press, 2000. 
. Bounded Rationality and the World Political Economy: the Nature of Decision Making. In: ANDREWS, David; HENNING, Randall; PAULY, Louis (Eds.) Governing the World's Money. Ithaca, Cornell University Press, 2002.

Negotiating Trade: Developing Countries in the WTO and NAFTA. Cambridge: Cambridge University Press. 2006

. Breaking Deadlocks in International Institutional Negotiations: The WTO, Seattle, and Doha. International Studies Quarterly, v. 53, n. 2, p. 273-299, 2009.

ORTIZ MENA L. N., A. Getting to "No:" Defending against demands in NAFTA energy negotiations. In: ODEL, J. S. Negoatiating Trade: Developing Countries in the WTO and NAFTA. Cambridge University Press, 2006.

OSTROM, E. A Behavioral Approach to the Rational Choice Theory of Collective Action: Presidential Address, American Political Science Association, 1997. The American Political Science Review, v.92, n.1, p. 1-22, mar. 1998.

OSTRY, Silvia. The Uruguay Round North South Grand Bargain: Implications for Future Negotiations. The Political Economy of International Trade Law. University of Minnesota, 2000. PANITCHPAKDI, S. Cancún should pave the way for timely DDA conclusion. WTO, 2003. Disponível em:

<https://www.wto.org/english/thewto_e/minist_e/min03_e/brief_e/brief01_e.htm>. Acesso em: 25 jan 2015

PORTMAN, R. Opening Statement by U.S. Trade Representative Rob Portman. 14 dez. 2005. Disponível em: <http://2001-2009.state.gov/e/eeb/rls/rm/2005/58045.htm>. Acesso em: 25 jan 2015

POUNDSTONE, W. Prisoner's Dilemma: John vou Neumann, Game Theory, and the Puzzle of the Bomb. Nova Iorque: Doubleday, 1992.

PUTNAM, R. D. Diplomacy and Domestic Politics: The Logic of Two-Level Games. International Organization, v.42, n. 3,p. 427-460, 1988.

RAIFFA, H. The Art and Science of Negotiation. Cambridge: Harvard University Press, 1982.

RAMANZINI JUNIOR, H.; MARIANO, M. Brazil and the G-20: Domestic Pressures and the Construction of the Negotiating Position in the Doha Round of the WTO. Journal of World Trade, v. 47, p. 1203-1224, 2013.

RODRIK, D. How Far Will International Economic Integration Go?. Journal of Economic Peispectives, v.14, n.1, p. 177-186, 2000.

ROLLAND, S. Development at the WTO. Oxford: Oxford University Press, 2012. 
ROLLAND, S. Redesigning the negotiation process at the WTO. Journal of International Economic Law. Oxford: v. 13, n. 1, p. 65-110, 2010.

RUGGIE, J. G. International Regimes, Transactions, and Change: Embedded Liberalism in the Postwar Economic Order. International Organization, v.36, n.2, 1982, p.379-415.

SIMON, H. A. A Behavioral Model of Rational Choice. The Quarterly Journal of Economics, v. 69, n. 1, p.99-118, 1955.

. Bounded Rartionality in Social Science: Today and Tomorrow. Mind \& Society, v.1, n.1, p.25-39, 2000.

STRICKNER, A.; SMALLER, C. Doha is not dead just yet, but what exactly has been saved? Institute for Agriculture and Trade Policy, Geneva. Out 2004. Disponível em:

<http://www.globalexchange.org/news/doha-not-dead-just-yet-what-exactly-has-been-saved>. Acesso em: 25 jan 2015

SUBRAMANIAN, A. Too Much Legitimacy Can Hurt Global Trade. Financial Times, 13 jan. 2013. Disponível em: <http://www.ft.com/cms/s/0/28886cb6-5c23-11e2-bef7-

00144feab49a.html>. Acesso em: 08 jul 2013.

SUTHERLAND, P. et al. The Future of the WTO: Addressing Institutional Challenges in the Millennium. Genebra: WTO, 2004. Disponível em:

<http://www.wto.org/english/thewto_e/10anniv_e/future_wto_e.pdf> Acesso em: 02 jul 2014.

THE CAIRNS GROUP. Background on the Cairns Group and the WTO Doha Round. [s.d.].

Disponível em : 〈http://cairnsgroup.org/Pages/wto_negotiations.aspx>. Acesso em: 25 jan 2015

THE ECONOMIST. Hard truths in Hong Kong. Dez 2005. Disponível em:

<http://www.economist.com/node/5326711>. Acesso em: 25 jan 2015

THIRD WORLD NET (TWN). NGOs criticize Cancun draft, preparatory process. 26 ago. 2003. Disponível em: <https://www.google.com.br/webhp?sourceid=chromeinstant\&ion=1\&espv=2\&ie=UTF-8\#q=translate $>$. Acesso em: 25 jan 2015

UNITED NATIONS CONFERENCE ON TRADE AND DEVELOPMENT (UNCTAD). About GSP. [s.d]. Disponível em: <http://unctad.org/en/Pages/DITC/GSP/About-GSP.aspx>. Acesso em: 25 jan 2015

US Government Acountability Office [GAO]. World Trade Organization: Limited Progress at Hong Kong Ministerial Clouds Prospects for Doha Agreement. 27 abr. 2006. Disponível em: <http://www.gao.gov/assets/250/249926.html>. Acesso em: 25 jan 2015

VANGRASSTEK, C. The History and Future of the World Trade Organization. WTO, 2013. Disponível em: <https://www.wto.org/english/res_e/booksp_e/historywto_e.pdf>. Acesso em: 25 jan 2015 
VANGRASSTEK, C.; SAUVÉ, P. The consistency of WTO rules: can the single undertaking be squared with variable geometry? Journal of International Economic Law. v. 9, n. 4, p. 837-864, 2006.

WIRJAWAN, G. Concluding Remarks - WTO’s Ninth Ministerial Conference. Bali, Indonésia, 07 dez. 2013. Disponível em:

<http://www.wto.org/english/news_e/news13_e/mc9sum_07dec13_e.htm\#chairmans>. Acessado em 02 jul. 2014.

WOLFE, R. Crossing the river by feeling the stones: where the WTO is going after Seattle, Doha and Cancun. Review of International Political Economy, v. 11, n. 3, pp. 574-596, 2004.

WORLD TRADE ORGANIZATION (WTO). Ministerial Conferences. [s.d.]. Disonível em: <https://www.wto.org/english/thewto_e/minist_e/minist_e.htm>. Acesso em: 25 jan 2015

. Ministerial declaration, adopted on 20 May 1998. 1998a. Disponível em:

<https://www.wto.org/english/thewto_e/minist_e/min98_e/mindec_e.htm>. Acesso em: 25 jan 2015

Declaration on global electronic commerce - adopted on

20 May 1998. 1998b. Disponível em:

<https://www.wto.org/english/thewto_e/minist_e/min98_e/ecom_e.htm>. Acesso em: 25 jan 2015

Doha launches negotiations, TNC oversees them. 2003a Disponível em:

<https://www.wto.org/english/thewto_e/minist_e/min03_e/brief_e/brief02_e.htm WTO>. Acesso em: 25 jan 2015

Draft Cancún Ministerial Text. 2003b. Disponível em:

<https://www.wto.org/english/thewto_e/minist_e/min03_e/draft_decl_e.htm >. Acesso em: 25 jan 2015

Cover letter of the draft Cancún Ministerial Text. 2003c. Disponível em:

<https://www.wto.org/english/thewto_e/minist_e/min03_e/draft_decl_covletter_e.htm>. Acesso em: 25 jan 2015

Agriculture - Framework Proposal. 04 set. 2003d. Disponível em:

$<$ https://docsonline.wto.org/dol2fe/pages/ss/directdoc.aspx?filename=t $\% 3 \mathrm{a} \% 2 \mathrm{fwt} \% 2 \mathrm{fmin} 03 \% 2 \mathrm{f}$ w6.doc\&>. Acesso em: 25 jan 2015

Implementation of paragraph 6 of the Doha Declaration on the TRIPS Agreement and public health. 01 set. 2003e. Disponível em:

<https://www.wto.org/english/tratop_e/trips_e/implem_para6_e.htm>. Acesso em: 25 jan 2015 
Day 1: Conference kicks off with 'facilitators' named and cotton debated. 10 set. $2003 \mathrm{f}$. Disponível em:

<https://www.wto.org/english/thewto_e/minist_e/min03_e/min03_10sept_e.htm>. Acesso em: 25 jan 2015

Day 2: Cambodia and Nepal membership sealed as ministers start negotiations. 11 set. 2003g. Disponível em:

<https://www.wto.org/english/thewto_e/minist_e/min03_e/min03_11sept_e.htm>. Acesso em: 25 jan 2015

Day 3: 'Facilitators' start work on new draft declaration. 12 set. 2003h. Disponível em: <https://www.wto.org/english/thewto_e/minist_e/min03_e/min03_12sept_e.htm>. Acesso em: 25 jan 2015

Day 4: as ministers comment on new draft, Chairperson warns of dangers of failure. 13 set. 2003i. Disponível em:

<https://www.wto.org/english/thewto_e/minist_e/min03_e/min03_13sept_e.htm>. Acesso em: 25 jan 2015

Day 5: Conference ends without consensus. 14 Set. 2003j. Disponível em:

<https://www.wto.org/english/thewto_e/minist_e/min03_e/min03_14sept_e.htm>. Acesso em: 25 jan 2015

Jargon Buster: An informal guide to 'WTOspeak'. 2005a. Disponível em:

<https://www.wto.org/english/thewto_e/minist_e/min05_e/brief_e/brief26_e.htm>. Acesso em: 25 jan 2015

. Day 1: Conference opens formally and ministers consult on industrial goods. 13 dez. 2005b. Disponível em:

<https://www.wto.org/english/thewto_e/minist_e/min05_e/min05_13dec_e.htm>. Acesso em: 25 jan 2015

. Day 2: Convergence elusive on first full day of consultations; cotton also discussed. 14 dez. 2005c. Disponível em:

<https://www.wto.org/english/thewto_e/minist_e/min05_e/min05_14dec_e.htm>. Acesso em: 25 jan 2015

Day 3: Tonga All Set To Join, As Movement Seen In Talks On Least-Developed Countries. 15 dez. 2005d. Disponível em:

<https://www.wto.org/english/thewto_e/minist_e/min05_e/min05_15dec_e.htm>. Acesso em: 25 jan 2015

Day 4: Ministers start preparing revised draft ministerial text. 16 dez. 2005e. Disponível em: 〈https://www.wto.org/english/thewto_e/minist_e/min05_e/min05_16dec_e.htm>. Acesso em: 25 jan 2015 
Day 5: Revised draft circulated, ministers comment. 17 dez 2005f. Disponível em: <https://www.wto.org/english/thewto_e/minist_e/min05_e/min05_17dec_e.htm>. Acesso em: 25 jan 2015

Understanding the WTO (Fifth Edition). Genebra: World Trade Organization, Information and External Relations Division, 2015. Disponível em:

<https://www.wto.org/english/thewto_e/whatis_e/tif_e/understanding_e.pdf>.Acesso em: 25 jan 2015

ZOELLICK, R. B. America will not wait for the won't-do countries. 22 set. 2003. Disponível em: <https://ustr.gov/archive/document_library/opeds/2003/america_will_not_wait_for_the_won'tdo_countries.html>. Acesso em: 25 jan 2015

USTR Zoellick remarks at the conclusion of WTO General Council Meeting, Geneva, Switzerland. 31 jul. 2004. Disponível em:

<https://ustr.gov/archive/document_library/ustr_speeches/2004/ustr_zoellick_remarks_at_the_co nclusion_of_wto_general_council_meeting,_geneva,_switzerl.html>. Acesso em: 25 jan 2015

YIN, Robert. Case Study Research: Design and Methods. 4a edição. Thousand Oaks: SAGE Publications, 2009. 